University of Pennsylvania Carey Law School

Penn Law: Legal Scholarship Repository

Faculty Scholarship at Penn Law

2012

\title{
Extralegal Punishment Factors: A Study of Forgiveness, Hardship, Good-Deeds, Apology, Remorse, and Other Such Discretionary Factors in Assessing Criminal Punishment
}

\author{
Paul H. Robinson \\ University of Pennsylvania Carey Law School \\ Sean Jackowitz \\ University of Pennsylvania Law School -- Student \\ Daniel M. Bartels \\ Columbia University Graduate School of Business
}

Follow this and additional works at: https://scholarship.law.upenn.edu/faculty_scholarship

Part of the Criminal Law Commons, Criminal Procedure Commons, Criminology Commons, Law and Psychology Commons, Law and Society Commons, Other Psychology Commons, Public Law and Legal Theory Commons, and the Quantitative, Qualitative, Comparative, and Historical Methodologies

Commons

\section{Repository Citation}

Robinson, Paul H.; Jackowitz, Sean; and Bartels, Daniel M., "Extralegal Punishment Factors: A Study of Forgiveness, Hardship, Good-Deeds, Apology, Remorse, and Other Such Discretionary Factors in Assessing Criminal Punishment" (2012). Faculty Scholarship at Penn Law. 353.

https://scholarship.law.upenn.edu/faculty_scholarship/353

This Article is brought to you for free and open access by Penn Law: Legal Scholarship Repository. It has been accepted for inclusion in Faculty Scholarship at Penn Law by an authorized administrator of Penn Law: Legal Scholarship Repository. For more information, please contact PennlawIR@law.upenn.edu. 


\title{
Extralegal Punishment Factors: A Study of Forgiveness, Hardship, Good Deeds, Apology, Remorse, and Other Such Discretionary Factors in Assessing Criminal Punishment
}

\author{
Paul H. Robinson, ${ }^{*}$ Sean E. Jackowitz, ${ }^{* *}$ and Daniel M. Bartels ${ }^{* * *}$
}

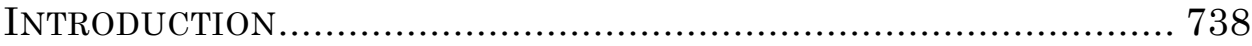

I. EXTRALEGAL PUNISHMENT FACTORS .............................. 740

A. Offender Reaction to the Offense ......................... 743

1. Acknowledgment of Guilt ......................... 743

2. True Remorse ....................................... 745

3. Apology ............................................... 746

B. Victim or Public Reaction to the Offense

(Unrelated to Desert)....................................... 747

1. Forgiveness by Victim .......................... 747

2. The Victim's Demand for Punishment......... 748

3. The Public's Demand for Punishment ......... 750

C. Offender Status or Characteristics (Unrelated to

Commission of the Offense) .................................. 751

1. Offender's Good Deeds or Character ........... 751

2. Offender's Bad Deeds or Character ............ 753

3. Rehabilitation ........................................ 755

4. Unique Talents or Special Value of

Contributions to Society ........................... 757

D. Suffering Apart from Official Punishment ............. 758

1. Special Offender Hardship Resulting from the Offense

* Colin S. Diver Professor of Law, University of Pennsylvania. The authors wish to acknowledge the significant contributions of Matthew Majarian and Tom Gaeta, University of Pennsylvania Law School Classes of 2011 and 2010, respectively.

** Member of the Class of 2012, University of Pennsylvania Law School; B.A., 2008, Yale University.

*** Assistant Professor of Marketing, Columbia University Graduate School of Business. 
2. Special Hardship from Punishment 760

3. Hardship for Offender's Family or Other

Third Parties. 761

4. Old Age 763

5. Payment of Substantial Civil

E. Conclusion 765 766

II. AN EMPIRICAL STUDY OF LAY INTUITIONS REGARDING EXTRALEGAL PUNISHMENT FACTORS .............................. 768

A. Previous Studies ............................................... 768

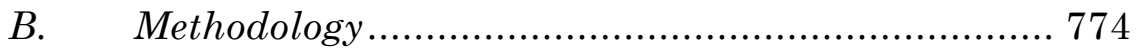

C. Support for Adjusting Punishment in Light of Extralegal Punishment Factors... 781

D. Effect of Baseline Offense on XPF Adjustments to Punishment.................................................... 785

E. Relative Relation Among XPFs by Popularity ........ 788

F. Demographic Differences................................. 791

1. Demographic Differences and Popularity .... 791

2. Demographic Differences and Magnitude.... 796

G. $\quad$ Local vs. National Differences............................. 801

H. Summary of Study Conclusions .......................... 804

III. IMPLICATIONS FOR CRIMINAL JUSTICE RULES AND PRACTICES 806

A. Disagreements About XPFs and the Problem of Disparity in Application 807

B. Strong Support for, or Opposition to, an XPF and the Problem of Undermining the Law's Moral Credibility

C. Empirical Support vs. Current Use of XPFs

1. Offender Reaction to the Offense

2. Victim or Public Reaction to the Offense

3. Offender Status or Characteristics Unrelated to Commission of the Offense

4. Suffering Apart from Official Punishment .. 822

\section{INTRODUCTION}

The criminal law's formal criteria for assessing punishment are typically contained in criminal codes, the rules of which fix an offender's liability and the grade of the offense. Those rules classically look to an offender's blameworthiness, taking account of both the 
seriousness of the harm or the evil of the offense and an offender's culpability and mental capacity. Courts generally examine these desert-based factors as they exist at the time of the offense. To some extent, modern crime-control theory sometimes prompts code drafters to look at circumstances beyond the offense itself, such as prior criminal record, on the grounds that these factors relate to the crimecontrol goals of deterrence and incapacitation. ${ }^{1}$

A look at how the punishment decisionmaking process actually works in practice, however, suggests that courts and other decisionmakers frequently go beyond the factors that the criminal law formally recognizes. These extralegal punishment factors ("XPFs") are the subject of this Article. ${ }^{2}$ XPFs include matters as diverse as an offender's apology, remorse, history of good or bad deeds, public acknowledgment of guilt, special talents, old age, extralegal suffering from the offense, forgiveness or outrage by the victim, and special hardship of the punishment for the offender or his family. These XPFs can make a difference at any point in the criminal justice process at which decisionmakers exercise discretion, such as when prosecutors decide which charge to press, when judges decide which sentence to impose, when parole boards decide when to release a prisoner, and when executive officials decide whether to grant clemency. They also make a difference in less visible exercises of discretion, such as in decisions by police officers and trial jurors.

What effect, if any, are these XPFs having in the exercise of discretion by criminal justice decisionmakers? What effect should they have? If such XPFs should be taken into account, how should this be done? These are the questions addressed here.

Part I of the Article sketches out a variety of XPFs and illustrates decisionmakers' reliance on them. For each XPF examined here, some claim has been made, through explicit argument or open

1. See generally Paul H. Robinson, Distributive Principles of Criminal LaW: Who Should BE PUNISHED How Much? (2008) (addressing the various considerations commonly utilized in apportioning punishment).

2. Not included within this study are factors that the formal liability and punishment rules do not take into account and that no one would seriously claim should be taken into account, such as race or beauty. There is some evidence that people might well take such factors into account, in some cases perhaps subconsciously. See, e.g., David A. Abwender \& Keyatta Hough, Interactive Effects of Characteristics of Defendant and Mock Juror on U.S. Participants' Judgment and Sentencing Recommendations, 141 J. Soc. PsYchoL. 603, 606-10 (2001) (demonstrating through empirical study that the physical attractiveness of an offender may be influential in punishment determinations by juries); Paul Skolnick \& Jerry I. Shaw, The O.J. Simpson Criminal Trial Verdict: Racism or Status Shield?, 53 J. Soc. IssuES 503, 503 (1997) (finding that considerations of race may play a role in punishment determinations). Presumably no one would argue that a criminal justice system should take such factors into account. 
practice, that reliance on the factor in determining punishment is appropriate. The support for some XPFs has blossomed into official approval in appellate court opinions or in sentencing guidelines, usually signaling to decisionmakers that the factor may be relied on, but rarely requiring such reliance.

There are good reasons to want to know how people feel about $\mathrm{XPFs}$ as a basis for adjusting punishment. First, these judgments can tell us something about how people are exercising their discretion in the current system, a fact that is difficult to document because such discretionary judgments are commonly out of public view. Further, as Robinson has argued elsewhere, there can be practical benefits to a criminal justice system that builds moral credibility with the community it governs, which can be done by imposing criminal liability and punishment only when and to the extent that the community will view as just. A system perceived as unjust provokes resistance and subversion; inspires vigilantism; and loses the power to stigmatize conduct, to gain compliance in borderline cases, and to shape powerful societal and internalized norms. ${ }^{3}$

The Part I discussion of each XPF uses previous studies, which are rare, and reports their findings regarding people's intuitions of justice on the subject. Part II reports the results of our empirical study of lay intuitions regarding these factors, examining which factors seem to have intuitive support among laypersons and to what extent. Part III takes up the implications of these findings for criminal justice reform.

\section{EXTRALEGAL PUNISHMENT FACTORS}

$\mathrm{XPFs}$, as defined here, include any factor that may influence the determination of what punishment an offender should receive other than (1) factors relating to the harm or evil of the offense, (2) factors relating to the blameworthiness of the offender in committing the offense, and (3) factors relating to the classic coercive crimecontrol principles of deterrence or incapacitation. Many, if not most,

3. For a fuller account, see RoBInson, supra note 1, at 175-210; Paul H. Robinson \& John M. Darley, Intuitions of Justice: Implications for Criminal Law and Justice Policy, 81 S. CAL. L. REv. 1, 1 (2007) [hereinafter Robinson \& Darley, Intuitions] (suggesting that judgments about justice are based more on intuition than on reasoning); Paul H. Robinson \& John M. Darley, The Utility of Desert, 91 Nw. U.L. REV. 453, 453 (1997) [hereinafter Robinson \& Darley, Utility] (arguing for a form of desert-based liability based on the community's shared principles of justice); Paul H. Robinson, Geoffrey P. Goodwin \& Michael D. Reisig, The Disutility of Injustice, 85 N.Y.U. L. REV. 1940, 1995-2025 (2010) (analyzing how a system's moral credibility and crimecontrol effectiveness are undermined by a distribution of liability that deviates from community perceptions of just desert). 
factors considered at sentencing, even discretionary factors, are not XPFs. The mental capacity of the offender may influence a judge's determination of the appropriate sentence, yet it is a factor that relates to the offender's blameworthiness and hence is not an XPF as defined here. The notion of "mercy" may be an XPF as defined here, but it in fact is sometimes used to refer to the consideration of factors like an offender's youth, prior record, or rotten social background, ${ }^{4}$ which relate directly to notions of blameworthiness and deserved punishment. A more narrow meaning of mercy, which refers to forgoing punishment that is in fact deserved, might well include reference to XPFs, such as forgiveness by the victim or hardship to the offender's family. ${ }^{5}$

Legislatures or sentencing commissions have recognized some XPFs as permissible grounds for aggravation or mitigation, but they rarely require that a sentencing judge take account of these XPFs in this manner. ${ }^{6}$ Rather, XPFs come into play when judges exercise their sentencing discretion, "taking into consideration various factors relating both to offense and offender." 7 In the federal context, for example, Congress clamped down on judicial discretion by creating the U.S. Sentencing Commission and empowering it to enact mandatory Sentencing Guidelines. ${ }^{8}$ But that discretion reemerged in the wake of

4. See, e.g., Richard Delgado, "Rotten Social Background": Should the Criminal Law Recognize a Defense of Severe Environmental Deprivation? 3 LAW \& INEQ. 9, 10 (1985) (suggesting that socioeconomic deprivation may mitigate criminal responsibility and warrant recognition as a criminal defense).

5. For several of the factors considered in this study, one could construct an argument that the factor related to the offender's blameworthiness for the offenses. For example, remorse after the offense might be viewed this way, even though it occurs only after the offense is complete. We include these factors in the study nonetheless because it is certainly not the accepted view that such factors, which did not exist at the time of the offense, affect an offender's blameworthiness for it.

6. In the Model Penal Code formulation, for instance, the presence of some XPF in a death penalty case may give rise to a mandatory mitigation. MODEL PENAL CODE $§ 210.6$ (2001) (withdrawn 2009).

7. Apprendi v. New Jersey, 530 U.S. 466, 481 (2000).

8. Congress created the U.S. Sentencing Commission order "to reduce 'unjustifiably wide' sentencing disparity." Stephen Breyer, The Federal Sentencing Guidelines and the Key Compromises Upon Which They Rest, 17 HofSTRA L. REV. 1, 4 (1988). In accordance with this goal, the Commission produced the Sentencing Guidelines, which substantially constrained judges' ability to sentence offenders ad hoc. "While a judge, pre-Guidelines, had the discretion to consider uncharged conduct or acquitted conduct, post Guidelines, it was mandatory, and that conduct came to have specific determinate consequences-an increase in one's sentencing score and a concomitant increase in one's sentence." Nancy Gertner, A Short History of American Sentencing: Too Little Law, Too Much Law, or Just Right, J. CRIM. L. \& CRIMINOLOGY 691, 702 (2010). 
the Supreme Court's decision in United States $v$. Booker, ${ }^{9}$ which "stripped the Guidelines of the force of law" and "enhanced the position of the judge" to make discretionary sentencing decisions. ${ }^{10}$ Thus, the decision of whether to mitigate or aggravate punishment in light of some XPF begins and often ends with the sentencing judge. As a result, consistency in the application of XPFs to specific cases is lacking, even though an XPF can have a real effect on the amount of punishment an offender receives. ${ }^{11}$

Rather than examine every plausible XPF, we look only at those for which there is some defensible argument that has been made, or could be made, for seriously taking the factor into account. For example, while some decisionmakers might in fact be influenced by an offender's race or physical attractiveness, ${ }^{12}$ no one seriously argues that such influences should be allowed. Our interest is in providing guidance to reformers, so we consider only those XPFs that have at least some colorable claim to legitimacy. The eighteen factors discussed below fit these criteria. None of the factors directly relate to offense harm, offender blameworthiness, or coercive crime-control principles, and each factor has at least either some apparent use in current practice or support by punishment theorists.

The eighteen XPFs are divided into four general categories: XPFs that relate to (1) the offender's reaction to his own offense, (2) the victim's or public's reaction to the offense, (3) the offender's status

9. See United States v. Booker, 543 U.S. 220, 245 (2005) (Breyer, J., remedial opinion) (finding "the provision of the federal sentencing statute that makes the Guidelines mandatory . . . incompatible with today's constitutional holding" (internal citations omitted)). Booker followed on the heels of Blakely $v$. Washington, in which the Supreme Court held that Washington's sentencing regime, insofar as it allowed a judge to base an upward departure on facts not found by a jury, ran afoul of the Sixth Amendment. Blakely v. Washington, 542 U.S. 296, 303-04 (2004).

10. Gertner, supra note 8, at 706. For instance, federal judges need not rely on "extraordinary circumstances" when imposing a sentence outside the Guidelines' range. Gall v. United States, 552 U.S. 38, 47 (2007). Moreover, sentencing decisions by district court judges today are reviewed by appellate courts under an "abuse-of-discretion standard," "[r]egardless of whether the sentence imposed is inside or outside the Guidelines range." Id. at 51. It should be noted, however, that the Guidelines continue to play an important role in federal sentencing. "Even after the Supreme Court declared mandatory application of the Guidelines to be unconstitutional, many judges ... continued to use the numbers in the Guideline framework as a point of reference." Gertner, supra note 8, at 706 .

11. In federal court, inconsistency in guideline departures was apparent even before Booker. See Michael S. Gelacek et al., Departures Under the Federal Sentencing Guidelines: An Empirical and Jurisprudential Analysis, 81 MINN. L. REV. 299, 363-65 (1996) (noting that departure decisions may be evaluated in light of applicable case law, Commission policy, and information presented in the Probation Officer's report).

12. See Abwender \& Hough, supra note 2; Skolnick \& Shaw, supra note 2. 
or character, and (4) the collateral hardship that normal punishment may cause the offender or third parties.

\section{A. Offender Reaction to the Offense}

An offender's conduct after an offense typically has no effect on his blameworthiness for the offense. All of the information necessary to assess blameworthiness generally exists as soon as the offense has been committed. Nonetheless, what an offender does after committing an offense may have an effect on the proper level of punishment, at least insofar as lay people intuit. This Section examines the XPFs that most commonly take into account postoffense conduct.

\section{Acknowledgment of Guilt}

Perhaps the most widely recognized XPF is a defendant's acknowledgment of guilt. In federal court, the discount is formalized: the U.S. Sentencing Guidelines Manual calls for a two-step decrease in offense level if "the defendant clearly demonstrates acceptance of responsibility for his offense." 13 The Guidelines' commentary lists seven factors for judges to take into account in determining whether a defendant qualifies, including the defendant's truthful admission of "the conduct comprising the offense[]" and "the timeliness of the defendant's conduct in manifesting the acceptance of responsibility." 14 The Commission has also noted that additional mitigation "may be warranted" when "the defendant voluntarily discloses to authorities the existence of, and accepts responsibility for, the offense prior to the discovery of such offense, and if such offense was unlikely to have been discovered otherwise."15 But a defendant who acknowledges his guilt only after he is convicted cannot expect much leniency. The Guidelines make clear that "this adjustment is not intended to apply to a defendant who puts the government to its burden of proof"; only in "rare situations" may an offender demonstrate acceptance of responsibility and go through the ritual of a trial. ${ }^{16}$

13. U.S. SENTENCING COMMISSION GUIDELINEs MANUAL § 3E1.1 (2010).

14. Id. $\S 3 \mathrm{E} 1.1 \mathrm{cmt} . \mathrm{n} .1$.

15. Id. § 5K2.16; see also United States v. Stewart, 154 F. Supp. 2d 1336, 1342 (E.D. Tenn. 2001) ("Even though the Commission has not explicitly enumerated extraordinary acceptance of responsibility as a favored basis for departure, it has indicated a departure may be appropriate where a defendant's assistance in the investigation and prosecution of his or her offense rises to a level beyond what one ordinarily sees in a standard case.").

16. U.S. Sentencing Commission Guidelines Manual $\S 3$ E1.1 cmt. n.2 (2010). Such departures are only available in "extraordinary" cases to offenders convicted of obstruction or similar crimes tending to impede administration of justice. See, e.g., United States v. Honken, 
Acknowledgment of guilt is also a powerful mitigator in many state courts. A few states parallel the federal guidelines with statutes providing that judges should consider a defendant's acknowledgment of guilt at sentencing. ${ }^{17}$ It is more common, however, for states to require more from defendants than merely an acknowledgment of their wrongdoing. New Jersey, for example, allows judges to consider "the willingness of the offender to cooperate with law enforcement authorities" as a mitigating factor. ${ }^{18}$ In fact, New Jersey judges are prohibited from considering a guilty plea without more, ${ }^{19}$ though in this regard New Jersey is an outlier. Other states allow mitigation when offenders provide assistance to authorities, but these states do not explicitly bar judges from considering an acknowledgment of guilt in and of itself. ${ }^{20}$ Some theorists have advocated for a reduction in punishment where an offender has admitted guilt, irrespective of his motivation. ${ }^{21}$

184 F.3d 961, 971 (8th Cir. 1999) (reversing a district court's sentence reduction for an offender who had both obstructed justice and later accepted responsibility, holding that "the mere fact of the guilty plea to the underlying offense, followed by an absence of post plea obstructive conduct is not by itself sufficient to establish an extraordinary case ...").

17. See GA. CODE ANN. § 17-10-2(a) (1974) (allowing a judge to consider a "plea[ of guilty" as a mitigating factor); N.C. GEN. STAT. § 15A-1340.16(e)(11) (1993) (listing as a mitigating factor when "[p]rior to arrest or at an early stage of the criminal process, the defendant voluntarily acknowledged wrongdoing in connection with the offense to a law enforcement officer"); P.R. LAWS ANN. tit. 33, § 4699 (2005) (designating situations where "[t]he convict accepted his accountability at some phase of the criminal prosecution" as mitigated); CAL. CT. R. 4.423(b)(3) (2007) (recognizing mitigating factors in cases where "[t]he defendant voluntarily acknowledged wrongdoing before arrest or at an early stage of the criminal process").

18. N.J. STAT. ANN. § 2C:44-1(b)(12) (1978).

19. Id. § 2C:44-1(c)(1) ("A plea of guilty by a defendant or failure to so plead shall not be considered in withholding or imposing a sentence of imprisonment.").

20. See ARK. CODE ANN. § 16-90-804(c)(1)(I) (1993) (allowing such a mitigation upon motion of the state); CoLO. REV. STAT. § 18-1.4-102(4)(h) (2003) (taking cooperation into account as a mitigating factor in capital cases); FLA. STAT. § 921.0026(2)(i) (1997) ("The defendant cooperated with the state to resolve the current offense or any other offense."); N.D. CENT. CODE $§ 12.1-32$ 04(14) (1973) ("The defendant cooperated with law enforcement authorities by bringing other offenders to justice, or otherwise cooperated."); TENN. CODE ANN. § 40-35-113(10) (1989) (“The defendant assisted the authorities in locating or recovering any property or person involved in the crime."). Some jurisdictions with sentencing guidelines have phrased the factor in similar terms. See D.C. Voluntary Sentencing Guidelines Manual § 5.2.3(7) (2010) ("The defendant has provided substantial assistance to law enforcement in the detection or prosecution of other offenders, and departure for this reason does not demean the seriousness of the defendant's crime or create an unacceptable risk to the safety of the community."); Mo. RECOMMENDED SENTENCING User GUIDE 15, 17, 23 (2011) ("The defendant has cooperated with law enforcement."); OR. ADMIN. R. 213008 0002(1)(a)(F) (2009) ("The offender cooperated with the state with respect to the current crime of conviction or any other criminal conduct by the offender or other person.").

21. See, e.g., Frank H. Easterbrook, Plea Bargaining as Compromise, 101 YALE L.J. 1969, 1974-78 (1992) (supporting right of defendants to negotiate sentences as a way to rationally avoid trial); Robert E. Scott \& William J. Stuntz, Plea Bargaining as Contract, 101 YALE L.J. 


\section{True Remorse}

"True remorse" involves a sincere expression of contrition for the commission of the offense. Such remorse might be expressed independently of, or in conjunction with, an acknowledgment of guilt. Several writers have advocated for the use of true remorse as a mitigator of punishment. Jeffrie Murphy writes that "[t]he repentant person has a better character than the unrepentant person, and thus the repentant person-on this theory-simply deserves less punishment than the unrepentant person." ${ }^{22}$ In the same vein, Austin Sarat has argued that "remorse blunts the edge of retribution; it engenders forgiveness .... [a]nd, if not forgiveness, remorse at least seems to call for mitigation of punishment." 23

Several jurisdictions treat true remorse as a discretionary consideration. The U.S. Sentencing Guidelines suggest that "a downward departure... might be considered where a defendant, motivated by remorse, discloses an offense that otherwise would have remained undiscovered." ${ }^{4}$ Many states similarly permit the use of remorse as a mitigating factor. ${ }^{25}$ The Florida Supreme Court, for example, has held that "any convincing evidence of remorse may properly be considered in mitigation of the sentence." ${ }^{26}$ As recently as 2002, the Indiana Supreme Court overturned a sentence due, in part, to a failure to consider testimony pertaining to the offender's expressions of remorse for her crime. ${ }^{27}$ Some state statutes also allow

1909, 1914 (1992) (arguing that under classical contract theory a defendant who gives up statutory entitlements should be expected to get a sentencing reduction in return).

22. Jeffrie Murphy, Repentance, Punishment, and Mercy, in Repentance: A Comparative Perspective 143, 157 (Amitai Etzioni \& David Carney eds., 1997).

23. Austin Sarat, Remorse, Responsibility, and Criminal Punishment: An Analysis of Popular Culture, in The PAssions of LAW 168, 169 (Susan Bandes ed., 1999).

24. U.S. Sentencing Commission Guidelines MANUAL § 5K2.16 (2004) (emphasis added).

25. E.g., State v. Trostle, 951 P.2d 869, 887 (Ariz. 1997); Jackson v. State, 684 So. 2d 1213, 1238 (Miss. 1996); State v. Allen, 994 P.2d 728, 764 (N.M. 2000).

26. Pope v. State, 441 So. 2d 1073, 1078 (Fla. 1983). Florida also recognizes remorse as a mitigating factor by statute. FLA. STAT. § 921.0026(2)(j) (1997) (recognizing as a mitigating factor when "[t]he offense was committed in an unsophisticated manner and was an isolated incident for which the defendant has shown remorse.").

27. Crawford v. State, 770 N.E.2d 775, 783 (Ind. 2002). Other courts have held similarly. See, e.g., State v. McKinney, 946 P.2d 456, 458 (Alaska Ct. App. 1997) (mitigating a sex abuse conviction when the family desired reunification); Commonwealth v. Mills, 764 N.E.2d 854, 866 n.9 (Mass. 2002) (noting that a defendant's willingness to admit guilt is a proper factor for consideration in more lenient sentencing); State v. Graham, 308 S.E.2d 311, 315 (N.C. 1983) (giving great weight to confessions as a mitigation factor as "admission[s] of culpability, responsibility and remorse"); State v. Buttrey, 756 S.W.2d 718, 722 (Tenn. Crim. App. 1988) (considering defendant's remorse as a mitigating factor but offsetting it with defendant's previous criminal history). 
evidence of a lack of remorse to be used as an aggravator for criminal sentencing. ${ }^{28}$ State courts in some instances have sanctioned aggravation for lack of remorse through case law. ${ }^{29}$ Analyses show that sentencing judges commonly give lighter punishment to remorseful offenders. ${ }^{30}$

\section{Apology}

A simple expression of apology from the offender to the victim of a crime is often thought to be worthy of consideration as a mitigating factor. ${ }^{31}$ The sentencing courts of most states draw a significant distinction, however, between apology and remorse, generally refusing to recognize the former as a legitimate reason to mitigate, at least not without some other indication that it signals the latter. "Courts often view [simple statements of apology] as per se inadequate and take offense to the notion that saying 'sorry' is enough." 32 Often, courts will closely parse the language of an offender's statement of apology in order to determine whether true remorse is present. Examples of such refusals to mitigate based on a close examination of an offender's apology abound: An Indiana court concluded that an offender's statement that he was "very sorry about what happened" was "equivocal at best' and 'well short of a full acceptance of responsibility.' "33 The Rhode Island Supreme Court similarly upheld a trial court's denial of apology-based mitigation on the grounds that " $[\mathrm{t}]$ he trial justice apparently detected no salt in [offender's] tears; nor do we."34 The Pennsylvania Superior Court affirmed a trial court's unmitigated sentence due to a lack of credible remorse, holding favorably that "in reply [to offender's apologies and

28. See OHIO REv. CoDE ANN. § 2929.12(D)(5) (1994) (noting lack of remorse as indicating that the offender is likely to commit future crimes).

29. See, e.g., McAbee v. State, 770 N.E.2d 802, 806 (Ind. 2002) (allowing lack of remorse as a statutory "aggravating factor" adding ten years to defendant's sentence); People v. Griswold, 747 N.Y.S.2d 872, 873 (App. Div. 2002) (upholding sentence given defendant's lack of remorse); State v. Mollicone, 746 A.2d 135, 138 (R.I. 2000) (same); State v. Clegg, 635 N.W.2d 578, 580 (S.D. 2001) (inferring lack of remorse from defendant's "continued refusal to take accountability").

30. See, e.g., Stanton Wheeler et Al., Sitting in Judgment: The Sentencing of WhiteCOLLAR CRIMINALS 115-18 (1992) (noting that remorse and contrition count in all kinds of cases, not just white-collar cases, and that they count more for defendants without a prior record).

31. Bibas has advanced utilitarian arguments for such consideration, though again they do not claim that such apologies affect offenders' blameworthiness. See infra note 38 and accompanying text.

32. Bryan H. Ward, Sentencing Without Remorse, 38 LOY. U. CHI. L.J. 131, 143 (2006).

33. Id. at 144 (quoting Price v. State, 765 N.E.2d 1245, 1253 (Ind. 2002)).

34. Id. at 144-45 (quoting State v. Thornton, 800 A.2d 1016, 1045 (R.I. 2002)). 
excuses] the sentencing court noted '[w]e heard your talk . . . but talk is cheap. You are judged on your actions." "35

One area in which a bare apology (without any indication of remorse) seems to be acceptable for consideration in state courts is in capital sentencing, during which sentencing juries may "not be precluded from considering, as a mitigating factor, any aspect of a defendant's character or record and any of the circumstances of the offense that the defendant proffers as a basis for a sentence less than death." ${ }^{6}$ The sentencing jury is, of course, not required to give weight to all mitigating factors advanced by the offender, but states cannot prohibit consideration of an apology in capital sentencing. ${ }^{37}$

\section{B. Victim or Public Reaction to the Offense (Unrelated to Desert)}

Parties other than the offenders in criminal cases may exert influence on the amount of punishment imposed. XPFs involving such parties include opinions and representations to the court made by victims or third parties, many of whom have no relation to the events that led to the prosecution, but who are nonetheless interested in the punishment imposed on the offender.

\section{Forgiveness by Victim}

In the unusual case in which a victim forgives an offender prior to sentencing, an argument might be made that the victim's feelingseven absent requests for leniency-should play a role in determining the appropriate punishment. Stephanos Bibas has argued that "the state should take the victim's interests into account by giving weight to the victim's forgiveness." 38 According to Bibas, doing so will promote emotional healing on the part of the victim, will humble the offender, will place the victim above the offender in the societal power continuum, and will satisfy the victim's psychological needs. ${ }^{39}$

Courts routinely hear victim opinions through victim-impact statements. Indeed, forty-eight states protect the rights of victims to participate in allocution in sentencing, and in the remaining two

35. Commonwealth v. Tirado, 870 A.2d 362, 367 (Pa. Super. Ct. 2005).

36. Lockett v. Ohio, 438 U.S. 586, 604 (1978) (emphasis omitted).

37. Id. at $604-05$.

38. Stephanos Bibas, Forgiveness in Criminal Procedure, 4 OHIO ST. J. CRIM. L. 329, 338 (2007).

39. Id. 
states judges have discretion to allow victim participation. ${ }^{40}$ Some victims will choose to use their statement as an opportunity to express forgiveness for the offender.

\section{The Victim's Demand for Punishment}

As opposed to the simple fact of victims' emotional expressions, this punishment factor concerns actual demands by a victim or some other party for either greater or lesser punishment. Such punishment demands may arise apart from any forgiveness on the part of the victim. The life sentence imposed on Aaron McKinney, one of two teenagers convicted for the brutal murder of Matthew Shepard, is illustrative. ${ }^{41}$ Although Shepard's parents never forgave McKinney for his crime, they insisted that prosecutors refrain from seeking the death penalty. ${ }^{42}$ Instead, McKinney was given a plea agreement of life in prison without parole. ${ }^{43}$

Some scholars have argued in favor of permitting victims to express their views of the appropriate level of punishment. ${ }^{44}$ While it is common practice to allow victims to offer general impact statements, only a few states give crime victims a right to offer sentence recommendations. ${ }^{45}$ In some states, victim-impact statements are expressly forbidden from including sentencing requests. In Texas, for example, victims are generally precluded from offering such opinions. ${ }^{46}$ The Texas Court of Appeals has held that

40. Paul G. Cassell, In Defense of Victim Impact Statements, 6 OHIо ST. J. CRIM. L. 611, 615 (2009).

41. Susan Bandes, When Victims Seek Closure: Forgiveness, Vengeance, and the Role of Government, 27 FoRDHAM URB. L.J. 1599, 1600 (2000).

42. Id. At McKinney's sentencing hearing, Shepard's father said, "You robbed me of something very precious and I will never forgive you for that. Mr. McKinney, I give you life in the memory of one who no longer lives. May you have a long life and may you thank Matthew every day for it." Id. In addition to honoring their son's memory, the plea agreement meant "no drawn out appeals process, no chance of walking free on a technicality or receiving a lighter sentence and no opportunity for McKinney to become a symbol." Id.

43. Id.

44. Cassell has argued that such victim-impact statements "promote justice without interfering with any legitimate interests of criminal defendants .... [They] help convey valuable information to sentencing judges and have other beneficial effects." Cassell, supra note 40, at 611. In sum, Cassell writes, "crime victims should have the opportunity to provide a victimimpact statement at sentencing," and that statement should be taken into account before a sentence is imposed. $I d$. at 647.

45. See, e.g., OHIO Rev. CodE ANN. § 2930.13 (C)(4) (1994) (providing that victims can include in their statements a "recommendation for an appropriate sanction or disposition for the defendant”); Randell v. State, 846 P.2d 278, 280 (Nev. 1993) (construing NEv. REV. STAT. ANN. § 176.015 to allow victims to give testimony as to the proper sentence for an offender).

46. E.g., Gross v. State, 730 S.W.2d 104, 105-06 (Tex. Ct. App. 1987). 
"[o]n the question of punishment [the opinions of nonexpert witnesses] have little value, because the witnesses are in no better position to form an opinion than the jury itself, and the allowance of such opinions in evidence would constitute merely an appeal to sympathy or prejudice." 47

When victims express an opinion, they commonly request harsh punishment for the offender. ${ }^{48}$ For example, in one Nevada case, a victim stated, "I wish that [the offenders] would spend the rest of their lives in jail and that they would die there. And have every torment possible that a jail can give them." 49 Paul Cassell has argued that "even if victim-impact statements lead to harsher penalties in general or to a longer sentence in a particular case, that would hardly provide a convincing reason for banning them."50 Cassell bases this argument on the premise that "some emotion is inherently desirable in a criminal process." He suggests that victim-impact statements illustrate the emotional impact of the crime, which might not be properly understood if the victim were presented as a "shadowy abstraction.” 51

Less commonly, victims may request a lower sentence than is normally imposed. There are few examples in state courts of such victim requests for leniency. In 2009, the Michigan Court of Appeals affirmed the imposition of a sentence lower than the maximum permissible, observing that " $[\mathrm{t}]$ he trial court considered the victims' request for leniency and imposed a shorter sentence than it would have without the request."52 Similarly, another Michigan court affirmed a downward departure based on a victim's letter asking for leniency, explaining that "the request of the victim [and one other factor] 'keenly' and 'irresistibly' grab our attention and are of 'considerable worth' in deciding the length of the sentence." 53

The Florida District Court of Appeal came to the opposite conclusion when faced with a similar question: while "[t]he trial court also found that a downward departure sentence was justified based on the victim's request for a non-incarcerative sentence," the appeals court concluded that because "[g]enerally, mitigating circumstances

47. Id. at 106.

48. See Wayne A. Logan, Opining on Death: Witness Sentence Recommendations in Capital Trials, 41 B.C. L. REV. 517, 529 n.73 (2000) (collecting sources).

49. Randell, 846 P.2d at 279.

50. Cassell, supra note 40, at 636 .

51. Id.

52. People v. Smith, No. 284828, 2009 WL 2136903, at*3 (Mich. Ct. App. July 16, 2009).

53. People v. Washington, No. 235241, 2004 WL 243369, at*3 (Mich. Ct. App. Feb. 10, 2004). 
supporting a downward departure ameliorate the level of the defendant's culpability," the victim's request was not an acceptable ground for a downward departure. ${ }^{54}$ Nonetheless, this holding does not seem to be a categorical rule in Florida-while some cases have overturned downward departures based on victim requests, ${ }^{55}$ other Florida courts have approved of such departures. ${ }^{56}$ Courts have expressed a variety of views on the matter. ${ }^{57}$

\section{The Public's Demand for Punishment}

Public opinion is generally not considered an acceptable factor for a judge to consider in criminal sentencing. It may commonly play an important role but not one that is openly acknowledged. Presumably, a state's legislature already considered community views on appropriate levels of punishment when it graded offenses and set sentencing ranges or guidelines. Appellate courts generally regard any sentence modifications made by judges for this XPF to be in error. The Vermont Supreme Court, for example, overturned an aggravated sentence imposed after a trial judge allowed into evidence twenty-two petitions calling for a sentence increase. The court held that

[t]he trial judge appears to have been influenced by these petitions and the close public scrutiny at the sentence review hearing. By admitting the petitions into evidence he unwittingly injected bias, prejudice and public clamor into the case. [We thus] must remand the case $\ldots$ and require that the hearing be held before a different judge. ${ }^{58}$

The New Jersey Supreme Court has come to the same conclusion under different facts, holding that "[p]remising a sentencing decision on public outcry against a particular defendant is no mere technical error. It is nothing less than the surrender of our

54. State v. Knox, 990 So. 2d 665, 669 (Fla. Dist. Ct. App. 2008)

55. See, e.g., State v. Ussery, 543 So. 2 d 457, 457 (Fla. Dist. Ct. App. 1989) (overturning a downward departure that had been granted by victim request).

56. See, e.g., State v. Bernard, 744 So. 2d 1134, 1136 (Fla. Dist. Ct. App. 1999); State v. Powell, 696 So. 2d 789, 791 (Fla. Dist. Ct. App. 1997).

57. Tennessee's Supreme Court has also addressed the issue of victim requests for leniency, striking down a trial court's grant of probation for an offender who caused his nephew's drowning death while fleeing from the police in a vehicle and crashing into a river. State v. Carter, 254 S.W.3d 335, 337 (Tenn. 2008). Though the trial court placed significant weight on the victim's request, the court decided that the offender's conduct was "sufficiently reprehensible and offensive . . . as to require incarceration to avoid depreciating the offense." Id. at 348. Thus, "while we appreciate the . . pleas for leniency, we are troubled by the message such leniency would send." Id. However, it seems that this was a highly fact-specific decision-while Tennessee may appear to frown upon deference to such requests for leniency, the state does appear to have adopted Texas's categorical rule against victim-impact testimony.

58. State v. Rice, 483 A.2d 248, 257 (Vt. 1984). 
criminal justice system to public pressure."59 Finally, the U.S. Supreme Court has also disapproved of the use of public opinion in sentencing, holding that

[t]here can be no doubt that [the constitutional safeguards attaching to criminal procedure] embrace the fundamental conception of a fair trial, and that they exclude influence or domination by either a hostile or friendly mob. There is no room at any stage of judicial proceedings for such intervention; mob law is the very antithesis of due process. ${ }^{60}$

Despite this bar on the consideration of public opinion, sentencing judges are still confronted with this kind of evidence. During the sentencing phase of the trial of Lewis "Scooter" Libby, the presiding judge received over two hundred letters expressing an opinion as to the appropriate punishment for Libby. ${ }^{61}$ While the judge in that case explicitly denied considering these letters, ${ }^{62}$ the possibility remains that other judges in similar situations might succumb to public pressure and consider public sentiment, regardless of whether such consideration is acknowledged.

\section{Offender Status or Characteristics (Unrelated to Commission of the Offense)}

Many of an offender's characteristics, though unrelated to his or her blameworthiness for the offense, nonetheless may influence the amount of punishment imposed. In assigning punishment, a decisionmaker may take into account, for example, the offender's status within the community, the offender's past actions or character, or the offender's present characteristics unrelated to the offense. Some have argued that many characteristics of this type ought to be considered in setting punishment for criminal offenses, despite the fact that they do not relate to the law's traditional desert or crimecontrol criteria for liability and punishment.

\section{Offender's Good Deeds or Character}

The previous good works of an offender can render him more sympathetic in the eyes of the community and, in some cases, in the eyes of the court. Peter Henning has argued that, at least in the

59. State v. Humphreys, 444 A.2d 569, 576 (N.J. 1982).

60. Cox v. Louisiana, 379 U.S. 559, 562 (1965).

61. See Scott Sundby, The Libby Letters: Reflections on Sentencing and Mercy in a Post Booker World 11 (Washington \& Lee Pub. Legal Studies Research Paper Series, Accepted Paper 2009-2, 2009), available at http://papers.ssrn.com/sol3/papers.cfm?abstract_id=1354254.

62. Id. 
context of white-collar crimes, "consideration of prior good works [is] an appropriate issue in deciding sentences for defendants."63 Other authors agree; Douglas Berman has written that

every sentencing system (guideline or otherwise) provides for sentence enhancements (often huge enhancements) based on such a record of prior bad deeds. Doesn't it make some logical sense for a sentencing system to similarly provide for sentence reductions based on a notable record of prior good deeds such as military service ${ }^{64}$

During the sentencing phase of most trials, prior convictions typically act as an aggravating factor. ${ }^{65}$ However, "[f]ew jurisdictions explicitly recognize prior good acts as a mitigating sentencing factor. Trial judges have occasionally reduced an offender's sentence on the basis of prior good actions that are unrelated to the conviction, such as military service or charitable work."66 Decisions recognizing good character as a mitigating factor have been overturned by higher courts or frowned upon by the U.S. Sentencing Commission. ${ }^{67}$ Unlike the federal courts, North Carolina explicitly addresses prior deeds and character in its sentencing provisions: the state's felony sentencing statute allows for mitigation in the case of a previous honorable discharge from the military 68 or if the person "has been a person of good character or has had a good reputation in the community." 69 Tennessee courts have recognized military service as a mitigating factor at sentencing, ${ }^{70}$ and several other states refer to "character" as a possible consideration in sentencing. ${ }^{71}$

63. Peter J. Henning, Prior Good Works in the Age of Reasonableness, 20 FED. SENT'G REP. 187, 187 (2008).

64. Douglas A. Berman, Sentencing Law and Policy: Should Prior Military Service Reduce a Sentence?, SENT'G L. \& POL'Y BLOG (Apr. 14, 2006, 9:12 AM), http://sentencing.typepad.com/ sentencing_law_and_policy/2006/04/should_prior_mi.html.

65. See, e.g., U.S. SENTENCING GUIDELINES MANUAL § 4A1.1 (2010) (instructing sentencing judges to take an offender's criminal history into account when setting his sentence); $c f$. Almendarez-Torres v. United States, 523 U.S. 224, 230 (1998) ("[P]rior commission of a serious crime . . . is as typical a sentencing factor as one might imagine.").

66. Carissa Byrne Hessick, Why Are Only Bad Acts Good Sentencing Factors?, 88 B.U. L. REV. 1109, 1111 (2008).

67. Id.

68. N.C. GEN. STAT. § 15A 1340.16(e)(14) (2011).

69. Id. § $15 \mathrm{~A} 1340.16(\mathrm{e})(12)$.

70. See, e.g., State v. Overton, No. $02 \mathrm{C} 019510$ CC00303, 1997 WL 287665, at *3 (Tenn. Crim. App. June 2, 1997) ("With respect to the appellant's military service, honorable military service may always be considered as a mitigating factor consistent with the purposes of the 1989 Sentencing Act.").

71. See, e.g., Wilson v. State, 777 So. 2d 856, 892-93 (Ala. Crim. App. 1999) (upholding death sentence but noting that it was a nonstatutory mitigating circumstance that two witnesses from the offender's church testified that he was a person of good character and participated in church activities); State v. Williams, 904 P.2d 437, 452-53 (Ariz. 1995) (holding that trial court correctly found a nonstatutory mitigating circumstance that the offender displayed good 
Although there is disagreement over the general issue, the picture is clearer in the context of capital sentencing. The Supreme Court held in Lockett $v$. Ohio that

the Eighth and Fourteenth Amendments require that the sentencer, in all but the rarest kind of capital case, not be precluded from considering, as a mitigating factor, any aspect of a defendant's character or record and any of the circumstances of the offense that the defendant proffers as a basis for a sentence less than death. ${ }^{72}$

Thus, the admissibility of evidence of good deeds or character is constitutionally guaranteed and may be introduced as a possible mitigating factor in the sentencing phase of all death penalty cases. ${ }^{73}$

On the federal level, the U.S. Sentencing Guidelines do allow for mitigation in rare instances outside of capital cases. As the Guidelines themselves state, "Military, civic, charitable, or public service; employment related contributions; and similar prior good works are not ordinarily relevant in determining whether a departure is warranted." ${ }_{4}$ The use of such evidence, under extraordinary circumstances, has been upheld in several circuits. ${ }^{75}$

\section{Offender's Bad Deeds or Character}

The consideration of an offender's bad character-distinct from his criminal history, which is often formally included in punishment criteria because of its usefulness in identifying dangerous offenders ${ }^{76}$-is often advanced as a factor appropriate for

character prior to murdering the victim because he was law abiding and had previously saved lives of others); In re Marquez, 822 P.2d 435, 448-49 (Cal. 1992) (holding that trial counsel was ineffective for failing to present mitigating evidence that included fact that his family members would have testified that he was a good son and brother, he worked hard, and he had good character traits); Dawson v. State, 581 A.2d 1078, 1108 (Del. 1990) (noting that it was mitigating that the offender offered to donate his kidney to his cousin), vacated, 503 U.S. 159 (1992); People v. Thompkins, 732 N.E.2d 553, 569-70 (Ill. 2000) (holding that defense counsel was ineffective for failing to present mitigation that included that the offender was a good family person, was kind, and may have saved the life of a youth officer who later became a police chief); State v. Marshall, 586 A.2d 85, 162 (N.J. 1991) (noting that the offender's character was shown by his civil, business, and philanthropic acts but affirming death penalty), supplemented by 613 A.2d 1059).

72. Lockett v. Ohio, 438 U.S. 586, 587 (1978).

73. See Hessick, supra note 66, at 1119 (discussing the Supreme Court's requirement that all mitigating evidence be allowed in death penalty cases).

74. U.S. SENTENCING GUIDELINES MANUAL § 5H1.11 (2010) (emphasis added).

75. See, e.g., United States v. Rioux, 97 F.3d 648, 663 (2d Cir. 1996) (holding defendant's downward departure was warranted in light of extraordinary circumstances); see also Jeffery L. Kirchmeier, A Tear in the Eye of the Law: Mitigating Factors and the Progression Toward a Disease Theory of Criminal Justice, 83 OR. L. REV. 631, 662 n.194 (2004) (collecting sources).

76. See U.S. Sentencing Guidelines Manual ch. 4, pt. A, introductory cmt. (2010) ("A defendant with a record of prior criminal behavior is more culpable than a first offender and thus deserving of greater punishment.”); see also U.S. SENTENCING COMM'N, MEASURING RECIDIVISM: 
consideration in punishment. ${ }^{77}$ For example, in his dissenting opinion in Dawson $v$. Delaware, Justice Thomas argued that evidence of a criminal offender's racism was relevant at sentencing. ${ }^{78}$ There, Thomas argued that the offender's racist character was itself evidence of other culpable conduct, and it was therefore appropriate to consider the evidence as a rebuttal to mitigating character evidence and as an indication of future dangerousness. ${ }^{79}$ Similarly, Garvey has argued that evidence of character, good or bad, can be appropriately considered for punishment purposes, albeit in the limited context of determining whether to grant or withhold mercy in capital sentencing. ${ }^{80}$

State courts commonly consider an offender's character and prior acts in sentencing, even when an offender's prior actions or characteristics are unrelated to the crime at issue. For example, the Indiana Supreme Court upheld a sentence based on a trial court's finding that the offender "was 'incorrigible' and had been away from home without permission" and "had given birth to two children by the age of eighteen." 81 On review, the court found these factors (among others) to be reasonable sentence aggravators. Arizona courts have similarly held that sentencing judges "should consider not only the circumstances of the offense charged but also the moral character and past conduct of the defendant himself' in assigning punishment. ${ }^{82}$

The Criminal History Computation of the Federal Sentencing Guidelines 15 (2004), available at http://www.ussc.gov/Research/Research_Publications/Recidivism/200405_ Recidivism_Crimina_History.pdf ("The empirical evidence shows that criminal history as a risk measurement tool has statistically significant power in distinguishing between recidivists and non-recidivists.").

77. Rachael A. Hill, Comment, Character, Choice, and "Aberrant Behavior": Aligning Criminal Sentencing with Concepts of Moral Blame, 65 U. CHI. L. REV. 975, 989 (1998) ("According to character theory, criminal actions serve as a lens through which to view an actor's character traits. If a particular action expresses bad character, the actor is morally blameworthy.”).

78. Dawson v. Delaware, 503 U.S. 159, 171 (1992) (Thomas, J. dissenting).

79. Id. at $173-74$.

80. See Stephen P. Garvey, "As the Gentle Rain From Heaven": Mercy in Capital Sentencing, 81 CoRnell L. REV. 989, 1029 (1996) (arguing that all character evidence-good or bad-is irrelevant to concerns of just punishment but may be considered for a different moral question of whether to extend mercy). "Mercy," as used by Garvey, distinguishes an offender's actual desert from the emotional response his situation evokes among a capital-sentencing jury. Garvey proposes that, because such emotional responses cannot be eliminated, it is appropriate to allow the consideration of extralegal factors as part of a separate "mercy phase" of sentencing. See id. at $1012-17$.

81. Davidson v. State, 558 N.E.2d 1077, 1091 (Ind. 1990).

82. State v. Castano, 360 P.2d 479, 480 (Ariz. 1961). 


\section{Rehabilitation}

Rehabilitation has had a tortuous history in American punishment law and practice. Previously forming the foundation of penal policy at both the federal and state level, ${ }^{83}$ rehabilitation has been roundly criticized as a vague, hard-to-apply concept in practice. ${ }^{84}$ Nevertheless, rehabilitation continues to play a role in some sentencing courts, particularly in states that still have indeterminate sentencing. ${ }^{85}$

Rehabilitation of an offender as a factor in determining punishment amount is most commonly considered at parole hearings, where the parole board might consider rehabilitation in its decision whether to grant early release. While in some cases rehabilitation may take place before sentencing, judges are more likely to consider an offender's potential for rehabilitation and impose less punishment in cases where rehabilitation seems likely. Some scholars, such as Mae Quinn, argue that "good defense lawyers have long collected mitigating evidence from the inception of the case and presented proof of rehabilitation, when appropriate, in plea negotiations and in seeking leniency at sentencing." 86 Particularly in the context of juvenile justice, defendants often argue that the potential for rehabilitation is a worthy consideration in sentencing. ${ }^{87}$

The U.S. Sentencing Guidelines provide that one of the factors that may be considered by the administrating court is "post-offense rehabilitative efforts (e.g., counseling or drug treatment)." 88 In applying this mitigation, the Eastern District of New York held that "rehabilitation 'cannot be served if a defendant can look forward to nothing beyond imprisonment'... It is doubtful whether [the

83. See Marvin E. Frankel, Criminal Sentences: LaW Without Order 7 (1973) (noting that in 1973, rehabilitation was a popular theory of punishment).

84. See generally id. (arguing that rehabilitation theory does not produce uniform judgments).

85. See Jeremy Travis \& Sarah Lawrence, The Urban Inst., Beyond the Prison Gates: The State of Parole in America 4-7 (2002), available at http://www.urban.org/UploadedPDF/310583_ Beyond_prison_gates.pdf (noting the continued prevalence of parole boards and indeterminate sentencing in America).

86. Mae C. Quinn, An RSVP to Professor Wexler's Warm Therapeutic Jurisprudence Invitation to the Criminal Defense Bar: Unable to Join You, Already (Somewhat Similarly) Engaged, 48 B.C. L. REV. 539, 574 n.181 (2007).

87. See, e.g., Connie de la Vega \& Michelle Leighton, Sentencing our Children to Die in Prison: Global Law and Practice, 42 U.S.F. L. REV. 983, 1008 (2008) ("The harsh sentences dispensed in adult courts do not take into account ... their potential for rehabilitation and reintegration into society.").

88. U.S. SENTENCING GUIDELINEs MANUAL § 3E1.1 cmt. n.1 (2010). 
normally imposed sentence] provides such hope." 89 The Second Circuit has concluded that, while it is inappropriate to provide harsher sentences to promote rehabilitation, this factor can be appropriate to consider for downward sentencing departures-giving reduced sentences to offenders who appear especially likely to be rehabilitated. 90

The Supreme Court recently endorsed rehabilitation as a punishment factor. In Pepper $v$. United States, ${ }^{91}$ the petitioner, who had been convicted of a drug offense, litigated his sentence for over five years. ${ }^{92}$ During that time, the petitioner not only completed a prison-based drug rehabilitation program, but he also enrolled in a local community college, attained a supervisory role at a part-time job, and started a family. According to the Court, this evidence of rehabilitation "support[ed] a downward variance from the advisory [Sentencing] Guidelines range." 93 The change in conduct since his initial sentence "provided the most up-to-date picture of Pepper's 'history and characteristics.' "94

In the states, courts have often held that potential for rehabilitation can be a mitigating factor. ${ }^{95}$ Interestingly, some states require consideration of the potential for rehabilitation in certain situations. In South Dakota, for example, "a life sentence should only be imposed where the facts and previous convictions make rehabilitation so unlikely that the interests of society are best served by lifetime incarceration." 96 Illinois has a broader requirement that rehabilitation be considered in sentencing: "There are dual

89. Simon v. United States, 361 F. Supp. 2d 35, 48 (E.D.N.Y. 2005).

90. United States v. Maier, 975 F.2d 944, 948 (2d Cir. 1992); see also In re Sealed Case, 573 F.3d 844, 849 (D.C. Cir. 2009) ("[S]entencing courts may not treat rehabilitation as a reason for a longer term of imprisonment.”); United States v. Manzella, 475 F.3d 152, 158 (3d Cir. 2007) (same); United States v. Harris, 990 F.2d 594, 596 (11th Cir. 1993) (same). Some circuits have allowed District Court judges to impose longer sentences in order to enable an offender's participation in a correctional treatment program. See, e.g., United States v. Hawk Wing, 433 F.3d 622, 630 (8th Cir. 2006) (upholding an upward departure for "rehabilitative goals").

91. Pepper v. United States, 131 S. Ct. 1229, 1229 (2011).

92. Id. at 1242 .

93. Id. at $1236-37$.

94. Id. at 1249 .

95. Skipper v. South Carolina, 476 U.S. 1, 5 (1986); State v. Schad, 788 P.2d 1162, 1172 (Ariz. 1989); State v. Smith, 863 P.2d 1000, 1009 (Mont. 1993); State v. Davis, 477 A.2d 308, 311 12 (N.J. 1984); State v. Godsey, 60 S.W.3d 759, 786 (Tenn. 2001); see also Hitchcock v. Dugger, 481 U.S. 393, 398 (1987) (criticizing the proceedings at the state level for permitting jury instructions to not consider evidence of nonstatutory mitigating circumstances).

96. State v. Bult, 529 N.W.2d 197, 200 (S.D. 1995). 
considerations in sentencing. The seriousness of the offense and rehabilitation of the offender both are to be given weight." 97

In most state and federal courts the consideration of an offender's rehabilitative potential is purely discretionary. Even where a court must consider rehabilitation, as in South Dakota or Illinois, considerable discretion still remains as to the amount of mitigation, if any, with which to credit the offender.

\section{Unique Talents or Special Value of Contributions to Society}

The special talents of an offender may be relevant to punishment decisions where the decisionmaker recognizes that punishment may deprive society of those talents. William Berry has argued,

\footnotetext{
A potential example of when such mitigation would be appropriate is one in which an essential contributor to an underprivileged community commits a minor offense, and the harm to the state of giving him a custodial sentence, because of the consequences of his corresponding absence, outweighs the small diminishment in achieving retributive or utilitarian punishment goals that results from mitigation. ${ }^{98}$
}

For example, a small-town doctor accused of theft might be given a reduced or nonincarcerative sentence so as to keep his medical services available to the town's citizens. Similarly, a great artist or novelist might be given a reduced sentence so that society will not be deprived of his artistic contributions.

In the context of punishment in military courts, some scholars have argued that an offender's special "talents" or "training" should be taken into account in sentencing. ${ }^{99}$ The value of the offender to his organization may be a mitigating factor worthy of consideration; a long sentence deprives the service of the offender's talents, and that deprivation must be balanced against the harm that the offender has caused. 100

An illustration of the consideration of unique talents can be seen in the dramatic story of Frank Abagnale, Jr. ${ }^{101}$ During a criminal career spanning several continents and ultimately costing the victims of his various scams over $\$ 2.5$ million, Abagnale gained extensive

97. People v. Young, 529 N.E.2d 497, 501 (Ill. 1988).

98. William W. Berry III, Extraordinary and Compelling: A Re-Examination of the Justifications for Compassionate Release, 68 MD. L. REV. 850, 883 (2009).

99. Russell W.G. Grove, Sentencing Reform: Toward a More Uniform, Less Uninformed System of Court Martial Sentencing, 1988 ARMY LAW. 26, 32 (suggesting that special training and talents, among other factors, be included in presentence reports).

100. Id.

101. See generally Frank W. Abagnale, JR. \& Stan Redding, Catch Me If You Can: The TRUE STORY OF A REAL FAKE (2000). 
knowledge and skill in the methods employed by counterfeiters and other fraudsters. ${ }^{102}$ Upon his ultimate capture, he was sentenced to serve twelve years in federal prison. ${ }^{103}$ Despite his sentence, Abagnale was released after serving fewer than five years on the condition that he use his knowledge and experience to assist the FBI-essentially using what he had learned as a criminal to capture other criminals. ${ }^{104}$ The use of his talents in apprehending criminals and preventing further crime had no bearing on his blameworthiness for his past offenses, but it may be argued that society as a whole benefitted more from the use of his talents than from his incarceration. ${ }^{105}$

\section{Suffering Apart from Official Punishment}

Finally, the appropriate punishment to be imposed on an offender may be affected by special hardship that the punishment would impose on the offender himself or on third parties that depend on or care for him. Old age is a specific example of this kind of special vulnerability to punishment's effect, but it also invokes sympathy for other reasons. Situations where an offender has already paid substantial civil compensation to the offender are also part of this aspect of the calculus of proper punishment.

\section{Special Offender Hardship Resulting from the Offense}

Many offenders suffer as a result of their actions irrespective of any criminal punishment levied. Should this self-caused suffering be taken into account in assessing punishment amount? Consider, for example, a drunk driver who accidentally kills his daughter in an auto accident. That the intoxicated driver is guilty of a crime is clear. However, unlike many others convicted of the same offense, such an offender must also endure the loss of a loved one. Should the emotional pain justify a reduction in punishment?

In many jurisdictions, an offender who has suffered as a result of the offense can introduce this suffering to argue for a reduced

102. Id. at $4-5$.

103. Id. at 281.

104. Id. at 284. Abagnale has since made a career of teaching others, both in and out of law enforcement, about issues of fraud prevention. ABAGNALE \& Associates (Feb. 20, 2012), http://www.abagnale.com.

105. It is notable that in the decades since his release, Abagnale has made full restitution to nearly all of his victims. Peter Ross, Man on the Run; The Racy Life of the World's Most Notorious Con Man Has Been Immortalised by Leonardo DiCaprio in Catch Me If You Can. But the Real Frank Abagnale is a Reformed Character Who's Now Chasing the Bad Guys for a Living, SUNDAY HERALD (Glasgow), Jan. 26, 2003, at 3. 
sentence. However, without an additional showing of exceptional circumstances, such suffering is generally not enough to justify a discounted sentence. In Michigan, for example, the state supreme court overturned a trial court's downward departure from state sentencing guidelines where the offender "had already paid a significant price for his crimes, namely the loss of his family and employment," on the grounds that "neither loss grabs our attention as being exceptional." 106 It seems likely that an "exceptional" amount of suffering could trigger a valid downward departure, but it is unclear what might constitute that level of suffering.

Similarly, in 2009 the Washington Supreme Court approved the use of such an XPF when it overturned an accomplice-to-DUI conviction. ${ }^{107}$ There, the defendant was the only survivor of a group of seven intoxicated persons involved in a single-car crash. ${ }^{108}$ Though the trial court found the defendant guilty, the supreme court reversed and wrote the following:

While we would not hesitate to condemn Hedlund's conduct as reprehensible and indeed criminal, neither do we find it absurd to say that she has been punished enough. Her lack of judgment permitted the loss of the lives of her fiancé as well as several friends, and she spent months rehabilitating from her own severe injuries; further legal penalties would be dwarfed by the suffering she has already endured. ${ }^{109}$

The federal courts have also approved some downward departures based on offenders' prior suffering. In sentencing an offender convicted of filing a false tax return, a trial court disregarded the U.S. Sentencing Guidelines' ten- to sixteen-month recommended sentence and instead imposed only a term of probation and a fine, noting in part that the offender had already suffered substantially and "had been treated for depression due to the stress of the instant investigation." 110 The D.C. Circuit affirmed the sentence, holding that the "District Court's conclusion rests on precisely the kind of defendant specific determinations that are within the special competence of sentencing courts."111

106. People v. Dean, No. 266438, 2006 WL 3077520, at *2 (Mich. Ct. App. Oct. 31, 2006).

107. City of Auburn v. Hedlund, 201 P.3d 315, 319-20 (Wash. 2009).

108. Id. at 319.

109. Id.

110. United States v. Gardellini, 545 F.3d 1089, 1091 (D.C. Cir. 2008) (quoting Hearing Transcript at 56 U.S. v. Gardellini, No. 06cr00355-01 (D.D.C. 2007)).

111. Id. at 1095 . 


\section{Special Hardship from Punishment}

Suffering resulting from an offender's official punishment is rarely a ground for mitigation-for good reason: punishment, at least in its retributivist justification, serves the purpose of causing an offender to suffer. However, in some cases, unusual hardship can result from the imposition of a traditional sentence. Hardship beyond that typically inherent in and intended by a sentence may be used as a mitigating factor, especially when the hardship is born by a dependent of the offender or another innocent third party. ${ }^{112}$ For example, a single parent who commits a crime for which he would normally be sentenced to a long prison term might receive a mitigated sentence because his child would be left with no guardian if the full sentence were imposed.

Other scholars argue that in some situations, the likelihood that punishment will cause atypical and severe harm to the offender could be justification for mitigation. ${ }^{113}$ William Berry has argued that "the early release of an inmate because of a terminal illness will not unduly compromise the utilitarian goals of incapacitation, deterrence, and rehabilitation. The terminal illness will substantially reduce the risk of dangerousness, [will reduce] the need for rehabilitation, and will not impede any deterrent effect of the sentence." 114 In short, the value inherent in compassion can outweigh the interests sacrificed by exercising it. Others agree with Berry's argument, but advocate different means to account for excessive hardships. For example, Kobil and others advocate the use of the clemency power in situations of old age or illness. If, for example, a ten-year sentence is given to an offender with a life expectancy of five years, these scholars argue that the punishment amounts to a life sentence and may be cruel or disproportionate. ${ }^{115}$ The recent compassionate release of Abdelbaset Ali Mohmed Al Megrani, convicted of involvement in the bombing of Pan Am Flight 103 in the late 1980s, is illustrative of this sort of argument. ${ }^{116}$ The Scottish Government allowed Al Megrani, suffering

112. See, e.g., 730 ILl. ComP. STAT. ANN. 5/5-5-3.1(a)(12) (West 2011) (noting imprisonment that would endanger the defendant's medical condition constitutes a mitigating factor).

113. Berry, supra note 98.

114. Id. at 885.

115. Daniel T. Kobil, The Quality of Mercy Strained: Wresting the Pardoning Power from the King, 69 TEX. L. REV. 569, 628-29 (1991).

116. Lockerbie Bomber Freed From Jail, BBC News (Aug. 20, 2009), http://news.bbc.co .uk/2/hi/uk_news/scotland/south_of_scotland/8197370.stm. 
from terminal prostate cancer and expected to live no more than three months, to return to his native Libya to die. ${ }^{117}$

The U.S. Sentencing Guidelines provide for a reduction in sentence where the offender suffers from "an extraordinary physical impairment... ; [for example,] in the case of a seriously infirm defendant, home detention may be as efficient as, and less costly than, imprisonment." 118 This provision has been applied to make departures from the Guidelines where, for example, a white-collar offender in extremely poor health was sentenced to probation and home detention in lieu of incarceration because imprisoning the offender might cause his death. ${ }^{119}$

Notably, there is another federal hardship provision, albeit one not often used: in the event of "extraordinary and compelling" terminal illness, debilitating physical condition, or death or incapacitation of the only family member who is able to care for a minor child, a prisoner may be released upon a motion by the director of the Bureau of Prisons. ${ }^{120}$ In practice, the Bureau of Prisons has used this "compassionate release" program extremely rarely and then only for terminally ill inmates. ${ }^{121}$

\section{Hardship for Offender's Family or Other Third Parties}

Compassionate release may be thought warranted when incarceration of a parent could cause hardship to dependents: "[I]n some situations, allowing an offender to care for his or her child could supplement the rehabilitative process by providing the inmate with an important responsibility. The impact on deterrence will be negligible and, as a result, will not forbid mitigation in this context."122

Both federal and state courts permit consideration of hardships inflicted upon third parties. The U.S. Sentencing Guidelines address this concern, stating that "family ties and responsibilities are not ordinarily relevant in determining whether a departure may be warranted." The Guidelines' commentary explains that, in order to

117. $I d$.

118. U.S. SENTENCING GUIDELINES MANUAL § 5H1.4 (2011).

119. United States v. Coughlin, Crim. No. 06-20005, 2008 WL 313099, at *5 (W.D. Ark. Feb. 1, 2008); see also United States v. Rioux, 97 F.3d 648, 662-63 (2d Cir. 1996) (upholding downward departure in sentencing for defendant who received a kidney transplant, for which he must receive regular tests and medicines, and which also led to bone disease); Simon v. United States, 361 F. Supp. 2d 35, 42-43 (E.D.N.Y. 2005) (imposing a reduced sentence on an offender suffering from severe medical conditions).

120. 18 U.S.C. $\S 3582(c)(2)$ (2006).

121. Berry, supra note 98 , at 866 .

122. Id. at 887. 
make a departure based on such factors, a court should look to a nonexhaustive list of factors, including danger to members of the offender's family as a result of the offense. Additionally, there are explicit requirements for a departure based on loss of caretaking or financial support. ${ }^{123}$ As noted above, both federal and state death penalty cases have much looser evidentiary standards at sentencing; as such, in many cases familial hardship is introduced as a mitigating factor. ${ }^{124}$

The states generally allow for mitigation based on potential harm to third parties caused by the extended incarceration of an offender. Indiana's Penal Code, for example, permits a sentence mitigation if "[i]mprisonment of the person will result in undue hardship to the person or the dependents of the person."125 Note, however, that the Indiana Supreme Court has held that mitigation is not required in these circumstances: "Many persons convicted of serious crimes have one or more children and, absent special circumstances, trial courts are not required to find that imprisonment will result in an undue hardship." 126 The use of third-party hardship as a mitigating factor (and its accompanying interpretation) is mirrored in many other states, ${ }^{127}$ though some states restrict the mitigation to extraordinary circumstances. New Jersey, for example, only allows a mitigation based on hardship when "having regard to the character and condition of the defendant, [the court] is of the opinion that his imprisonment would be a serious injustice which overrides the need to deter such conduct by others." 128 This "serious injustice" standard may only be met in extraordinary and unforeseen circumstances.

There is some evidence that this XPF surreptitiously plays a role in sentencing. In one 2007 study, trial judges in Pennsylvania were presented with factorial surveys comprised of short vignettes designed to test the judges' sentencing decisions for offenders in various familial roles (and whose punishments, it follows, would have

123. U.S. SENTENCING GUIDELINEs MANUAL §5H1.6 (2011); id., cmt. n.1(c).

124. See, e.g., People v. Ochoa, 19 Cal. 4th 353, 456 (Cal. 1998) ("Sympathy for a defendant's family is not a matter that a capital jury can consider in mitigation, but that family members may offer testimony of the impact of an execution on them if by so doing they illuminate some positive quality of the defendant's background or character.").

125. IND. CODE ANN. § 35-38-1-7.1(b)(10) (West 2011).

126. Dowdell v. State, 720 N.E.2d 1146, 1154 (Ind. 1999).

127. 730 Ill. Comp. Stat. AnN. 5/5-5-3.1(a)(11) (West 2011); N.C. Gen. Stat. AnN. § 15A1340.16(e)(17) (West 2011); N.D. CENT. CodE ANN. § 12.1-32-04(11) (West 2011).

128. State v. Roth, 471 A.2d 370, 383 (N.J. 1984). 
varying impacts on others). ${ }^{129}$ It was observed that judges were most likely to give significant decreases in the likelihood of incarceration for offenders in the role of caregiver (both "caregiver only" and "caregiver as well as financial provider"). ${ }^{130}$ This effect was observed for offenders of either sex for nearly all familial roles-the only familial role that did not significantly reduce the likelihood of incarceration was economic provider. ${ }^{131}$

\section{Old Age}

Youth is often taken as a consideration in criminal sentencing, as mandated by juvenile-offender provisions and other considerations specific to young offenders. Immaturity may prevent an appreciation of the wrongfulness of one's conduct and thereby undermine an offender's blameworthiness. Elderly offenders have no such claim to make, yet there is some support for old age as a mitigator. Von Hirsch and Ashworth, for example, have argued that age is a relevant consideration in setting appropriate levels of punishment, since it may take the prime years away from young offenders and may be unduly burdensome on older offenders. ${ }^{132}$

In practice, many states seem to have allowed the use of age as a factor in punishment. ${ }^{133}$ The Michigan Supreme Court has held that "a 'term of years' must be an indeterminate sentence less than life. It must be something that is reasonably possible for a defendant actually to serve."134 Importantly, however, this holding does not require that a court make a factual determination as to how long an offender is expected to live; it is only a general requirement for courts to consider. ${ }^{135}$ One study found that Pennsylvania judges were less likely to incarcerate older offenders and that older offenders received shorter

129. Tina L. Freiburger, The Effects of Gender, Family Status, and Race on Sentencing Decisions, 28 BEHAV. SCI. \& L. 378, 382-84 (2009).

130. Id. at 386-87.

131. Id. at 387. Strangely, black males received a significant reduction in likelihood of incarceration for having children and not offering to care for them. Id. at 390. This observation may be explained, in part, by judge's hesitance to participate in the surveys at all due to the inclusion of race; the study's author posited that this nonfamilial reduction in sentence may be evidence of overcompensation on the part of judges to ensure that a racial bias was not observed. Id. at 391.

132. Andrew Ashworth, Sentencing And Penal Policy 276-77 (1983) (arguing that equality of impact means that both older and younger offenders should receive a sentencing discount because of the special hardships prison would entail).

133. See, e.g., N.D. CENT. CodE ANN. § 12.1-32-04(12) (West 2011) (noting that "whether the defendant is elderly or in poor health" should be taken into consideration).

134. People v. Moore, 439 N.W.2d 684, 693 (Mich. 1989).

135. Id. 
sentences than their younger counterparts; however, the study offered little insight as to the causes of this discrepancy. ${ }^{136}$ Other studies have reached "conflicting conclusions" about the impact of old age on punishment. ${ }^{137}$

The U.S. Sentencing Guidelines state that "age may be a reason to depart downward in a case in which the defendant is elderly and infirm and where a form of punishment such as home confinement might be equally efficient as and less costly than incarceration." 138 At least two circuits have narrowly interpreted this provision, both of which require all four elements (age, infirmity, efficiency, and cost effectiveness) in order to allow a reduced sentence. ${ }^{139}$ Even within other, less strict circuits, the provision is rather rarely used. ${ }^{140}$

While several jurisdictions allow the use of age as a mitigating factor on a discretionary basis, at least one state explicitly forbids its consideration unless it has a direct implication for an offender's blameworthiness. Arizona courts have held that "extreme youth or old age only becomes a mitigating factor when, because of immaturity or senility, the defendant lacks substantial judgment in committing the crime." 141 The Tennessee Supreme Court has come to a similar conclusion based on a sentencing guideline much like Arizona's. ${ }^{142}$ That court's pronouncement only allows the consideration of old age as a punishment factor where age might implicate the offender's ability to "appreciate the nature of his conduct" and requires that age be viewed in context, considering "education, maturity, experience, mental capacity or development." 143

136. William E. Adams, Jr., The Intersection of Elder Law and Criminal Law: More Traffic Than One Might Assume, 30 StETson L. REv. 1331, 1346 (2001) (citing Darrell Steffensmeier \& Mark Motivans, Sentencing the Older Offender: Is There an "Age Bias"?, in ELDERS, CRIME, AND the Criminal Justice System: Myth, Perceptions, and Reality in the 21st Century 185, 197-99 (Max B. Rothman et al. eds., 2000)). Similar results were observed in the federal courts, despite the stricter guidelines applicable there.

137. Id. at 1346-47 (citing William E. Adams, Jr., The Incarceration of Older Criminals: Balancing Safety, Cost, and Humanitarian Concerns, 19 Nova L. REV. 465, 477-78 (1994)).

138. U.S. SENTENCING Guidelines MANUAL § 5H1.1 (2011).

139. See Thomas A. Long, Note, The Federal Sentencing Guidelines and Elderly Offenders: Walking a Tightrope Between Uniformity and Discretion (and Slipping), 2 ELDER L.J. 69, 75-76 (1994) (noting that the Third and Seventh Circuits require all four elements to be met).

140. Id. at 73 .

141. State v. de la Garza, 675 P.2d 295, 296 (Ariz. Ct. App. 1983), disapproved of on other grounds by State v. Thurlow, 712 P.2d 929, 932 (Ariz. 1986).

142. State v. Adams, 864 S.W.2d 31, 33 (Tenn. 1993).

143. Id. 


\section{Payment of Substantial Civil Compensation to the Victim}

Judges often adjust punishment in light of civil payments when the punishment is a fine or restitution. Indeed, when courts impose restitution orders, it is settled practice that they should offset the amount with "payments actually made by the defendant to the victim,"144 though the fact that a civil proceeding is pending is insufficient to reduce punishment. ${ }^{145}$ State courts often are statutorily authorized to mitigate sentences in light of substantial civil compensation. ${ }^{146}$

When pecuniary punishments are not solely at issue, federal courts under the U.S. Sentencing Guidelines have been hostile to the argument that restitution should reduce punishment. Allowing restitution to influence the sentencing decision, courts fear, may allow socioeconomic considerations to seep into the sentencing process. ${ }^{147}$ As the Sixth Circuit has noted, courts "may not sentence a poor convict more harshly than a rich convict simply because the rich convict is better able to make restitution." 148

Still, federal courts have acknowledged payment of civil compensation as a mitigating factor under section 3E1.1(a) of the Sentencing Guidelines on the theory that such payments demonstrate

144. Catharine M. Goodwin et Al., Federal Criminal Restitution $§ 14: 7$ (2010); see also 18 U.S.C. § 3664(j)(2) (2006) ("Any amount paid to a victim under an order of restitution shall be reduced by any amount later recovered as compensatory damages for the same loss by the victim in . . . any Federal civil proceeding; and . . . any State civil proceeding, to the extent provided by the law of the State.").

145. See GoODWIN ET AL., supra note 144, § 14.8 ("Even where a pending civil judgment or settlement is for the same harm as the restitution, courts generally disregard it in imposing restitution, because such a judgment might be subsequently changed, appealed, or amended.").

146. See Alaska Stat. ANN. $§ 12.55 .155(d)(8)$ (West 2011) (mitigating factor if defendant "fully compensated or made a good faith effort to fully compensate the victim"); CAL. R. CT. 4.423(b)(5) (West 2011) (including defendant making restitution to the victim as a mitigating factor); N.C. GEN. STAT. ANN. § 15A-1340.16(e)(5) (West 2011) (introducing a mitigating factor for defendant that has "made substantial or full restitution"); N.D. CENT. CODE ANN. § 12.1-32.04(6) (West 2011) ("[D]efendant has made or will make restitution . . . to the victim of his conduct for the damage or injury which was sustained."); TENN. CODE ANN. § 40-35-113(5) (West 2011) ("[D]efendant compensated or made a good faith attempt to compensate victim.").

147. See United States v. Chastain, 84 F.3d 321, 325 (9th Cir. 1996) ("Allowing a sentencing judge to reduce a defendant's sentence to preserve a defendant's job and facilitate restitution would introduce precisely the type of socio economic disparity into sentencing that the Guidelines were designed to eliminate.").

148. United States v. DeMonte, 25 F.3d 343, 347 (6th Cir. 1994); see also United States v. Grasser, 312 F.3d 336, 340 (7th Cir. 2004) ("Allowing sentencing courts to depart downward based on a defendant's ability to make restitution . . . would . . . create an unconstitutional system where the rich could in effect buy their way out of prison sentences." (quoting United States v. Seacott, 15 F.3d 1380, 1389 (7th Cir. 1994))). 
"acceptance of responsibility for [the defendant's] offense."149 On this theory compensation is not a sign of hardship, but rather an acknowledgment of guilt, and courts accordingly require the defendant's restitution to be accompanied by genuine expressions of sincerity. For instance, in United States $v$. Szarwark, the government succeeded in challenging the District Court's two-level reduction under section 3E1.1(a) when the defendant, who was convicted of mail fraud, failed to collect money owed to him by the victim after the victim discovered the fraud. ${ }^{150}$ The Seventh Circuit noted that the defendant's asserted restitution was "clearly not what the framers of the Sentencing Guidelines meant by voluntary payment."151 By contrast, in United States v. Oligmueller, the Eighth Circuit upheld a downward departure when the defendant there voluntarily began paying back a fraudulent loan more than a year before he was indicted, worked sixteen-hour days, turned over his life insurance deposit, took an outside job, and gave up his home all in order to redeem the debt. ${ }^{152}$

\section{E. Conclusion}

To conclude, the XPF discussions above suggest that, without guidance on the matter, different decisionmakers commonly can come to widely different views on whether to adjust punishment for an XPF. Such fundamental disagreements invite the common practice of basing the offender's punishment less on the offense committed, on the offender's blameworthiness for it, or on any rational crime-control policy and more on the defendant's good or bad luck in drawing a decisionmaker.

Much of what has been said above about reliance on XPFs has focused on courts and sentencing. This is so because it is only in this context that we can see XPFs in use, usually through appellate review or through the articulation of sentencing guidelines or policy statements. However, there is good reason to believe that the diversity of views on XPFs that we see among judges is found as well, perhaps with even greater diversity, among the other decisionmakers in the criminal justice process, especially those whose decisions are subject to less scrutiny or guidance. The less visible decisions by police

149. U.S. Sentencing Guidelines Manual § 3E1.1(a) (2011); see also id. cmt. n.1(c) ("In determining whether a defendant qualifies under subsection (a), appropriate considerations include ... voluntary payment of restitution prior to adjudication of guilt . . ..").

150. 168 F.3d 993, 997 (7th Cir. 1999).

151. $I d$.

152. United States v. Oligmueller, 198 F.3d 669, 670 (8th Cir. 1999). 
officers, prosecutors, jurors, parole boards, and clemency panels may take account of all, or none, of these XPFs. That is, not only is there little or no guidance for taking account of XPFs, there is little or no information about whether or how decisionmakers do take account of them.

One final point is worth mentioning. Although each of the factors discussed above is described on its own, in practice many may arise in combination with one or more other factors. An example may be the likelihood that a truly remorseful offender may apologize to his victim and may publicly acknowledge his wrongdoing. Such apologies also may be accompanied by victim forgiveness and possibly a victim request for reduced punishment.

The occurrence of multiple factors together is not unusual. In the Australian case of Hodder $v$. The Queen, ${ }^{153}$ for example, the Supreme Court of Western Australia was confronted with at least eight XPFs at once. The defendant brutally beat and repeatedly sodomized his wife after a night of drinking, threatening to kill her if she told the police. ${ }^{154}$ Once detained, Hodder admitted his offenses, expressed remorse, and apologized for what he had done. ${ }^{155} \mathrm{He}$ sought out assistance from Alcoholics Anonymous and brought his alcoholism in check. ${ }^{156}$ His wife, pregnant with a third child by the time of sentencing, wrote an impassioned letter on his behalf, expressing her forgiveness for her husband and noting both his good character and her confidence that the incident was an isolated one. ${ }^{157}$ She added, "It might hurt him to go to jail, but the person most affected would be me, as I'm pregnant without any family here whatsoever and can't really see myself coping financially or emotionally." 158 At sentencing she gave testimony reiterating her request that Hodder receive no jail time. ${ }^{159}$ Thus, in addition to assessing punishment based on Hodder's blameworthiness, the sentencing judge could have also considered his acknowledgment of guilt, expression of remorse, apology, prior good character, efforts at rehabilitation, obligation to his family, forgiveness of the victim, and the victim's specific request for reduced punishment. The sentencing judge nonetheless gave Hodder three years imprisonment. ${ }^{160}$ However, the Supreme Court of Western

153. (1995) 81 A Crim R 88, 1995 WL 1689433 (Austl.).

154. Id. at 89-90.

155. Id. at 90,92 .

156. Id. at 91 .

157. $I d$.

158. $I d$.

159. Id. at 92 .

160. Id. at 95 . 
Australia substituted it with a term of probation. ${ }^{161}$ The Chief Judge of the Court concluded, "In my view, of all the cases which have so far come before this Court, this one... fall[s] within the exceptional circumstances in which a non-custodial disposition was justified."162

It is also possible that particular XPFs may have particular interactive effect with other XPFs. For example, either a remorseless apology or true remorse (without apology) might persuade a judge to give a reduced sentence, but a remorseful apology might be far more effective. Similarly, an offender's bad character might be outweighed considerably by his potential for rehabilitation, but less so by obligations to his family (where, for example, the offender appears to be a poor influence on his children). Thus, a decisionmaker's judgment is likely to be a tough one if competing considerations are at issuewhich, in practice, may be fairly often. Given this reality, the need for conceptual clarity in understanding XPFs, which has heretofore been lacking, is especially weighty.

\section{AN EMPIRICAL STUDY OF LAY INTUITIONS REGARDING EXTRALEGAL PUNISHMENT FACTORS}

We undertook a study of lay people's intuitions regarding XPFs, investigating whether and to what extent such factors influence lay judgments about how much punishment offenders should receive. Our study was designed to elicit a basic understanding of the way in which people intuit XPFs and to build a foundation for additional research.

\section{A. Previous Studies}

No study has taken a comprehensive approach to lay intuition regarding punishment factors generally, though researchers have sometimes studied how people understand particular factors. For instance, studies historically have shown that remorse, apology, and acknowledgment of guilt have had an effect on how people perceive deserved punishment. ${ }^{163}$ When Alayna Jehle, Monika Miller, and Markus Kemmelmeier took up these factors in a 2008 study, however,

161. Id. at $104-05$.

162. Id. at 104.

163. See AARon LazARe, On Apology 111-17 (2004); Gregg J. Gold \& Bernard Weiner, Remorse, Confession, Group Identity and Expectancies about Repeating a Transgression, 22 BAsIC \& APPLIED Soc. Psychol. 291, 292 (2000); Steven. J. Scher \& John M. Darley, How Effective Are the Things People Say to Apologize? Effects of the Realization of the Apology Speech Act, 26 J. PSYCHOLINGUistic Res. 127, 128 (1997). 
they found that displays of remorse had little effect on punishment, even when accompanied by excuse or justification, and may have led to increases in punishment when no account of the offender's actions was offered. ${ }^{164}$ The Miller study may be distinguishable, however, since it asked participants to play the unique role of juror, possibly leading them to perceive remorse differently, even as evidence of deception. ${ }^{165}$

Similarly, many have studied offenders' statuses and characters, especially as they relate to punishment. ${ }^{166}$ Studies often appear to collapse these factors into one characteristic: social attractiveness. ${ }^{167}$ These studies of social attractiveness test many aspects of an offender's character germane to a typical sentencing inquiry, including career status, politeness, and volunteerism. ${ }^{168}$ David Lady and Elliot Aronson found that socially unattractive offenders received harsher sentences for the same conduct than socially attractive or neutral offenders. 169 Sentences selected for socially attractive and neutral offenders were not different with any statistical significance from each other. ${ }^{170}$ Nona Barnett and Hubert Field tested offender character more fully in a 1978 study. ${ }^{171}$ There, offender character was operationalized in a cleaner fashion, avoiding the effects of extraneous factors. ${ }^{172}$ The study further explored the

164. See, e.g., Alayna Jehle, Monika K. Miller \& Markus Kemmelmeier, The Influence of Accounts and Remorse on Mock Jurors' Judgments of Offenders, 33 LAW \& HUM. BEHAV. 393, 400 (2008).

165. Id. at 402. This may also have been caused by some of the mannerisms utilized by the actor featured in the mock trial videos - the actor was, in fact, attempting to deceive the jury.

166. See, e.g., Mark D. Alicke \& Ethan Zell, Social Attractiveness and Blame, 39 J. APPLIED Soc. PsychOL. 2089, 2100-02 (2009); Nona J. Barnett \& Hubert S. Field, Character of the Defendant and Length of Sentence in Rape and Burglary Crimes, 104 J. Soc. PsychoL. 271, 27576 (1978); Robert M. Bray et al., The Effects of Defendant Status on the Decisions of Student and Community Juries, 41 Soc. Psychol. 256, 257-59 (1978); David Landy \& Elliot Aronson, The Influence of the Character of the Criminal and His Victim on the Decisions of Simulated Jurors, 5 J. EXPERIMENTAL SOC. PSYCHOL. 141, 148-52 (1969).

167. Social attractiveness is also used interchangeably with "likeability." See Alicke \& Zell, supra note 166, at 2090. These characteristics can be operationalized as combinations of career status, politeness, and willingness to assist others. See id. at 2091-92 (listing descriptors used to influence respondents' assessments of social attractiveness); Landy \& Aronson, supra note 166, at 148 (including additional likely problematic factors, such as criminal history and injury sustained during offense).

168. Landy \& Aronson, supra note 166 , at $145,147-48$.

169. Id. at 151.

170. Id.

171. Barnett \& Field, supra note 166.

172. Barnett and Field provided mock jurors with similar case facts, but randomly assigned offender biographies that altered social attractiveness, gender, and race. $I d$. at 273 . The socially attractive condition was tested by describing the offender as a middle-aged stockbroker in a local firm who had maintained the same position for 10.5 years, was well liked by coworkers, was 
differing effects of offender character on punishment awards for different types of crime, providing vignettes of both rape and burglary. ${ }^{173}$ As might be expected, socially unattractive offenders received significantly longer prison terms than their socially attractive analogs when both were presented as having committed a rape. ${ }^{174}$ Oddly, however, there was no significant difference in assigned sentences between offenders of differing character for the burglary offense. ${ }^{175}$ This research suggests that the effects of these XPFs may be mediated by other, more traditionally legal factors, such as offense type. ${ }^{176}$ In a further exploration of the effect of offender character on assignment of blame, Mark Alicke and Ethan Zell moved away from the mock-jury methodology and instead focused on the presentation of compact vignettes. ${ }^{177}$ Their study provided student respondents with a vignette involving an assault and included information about the offender's social attractiveness. ${ }^{178}$ The study confirmed that social attractiveness has an effect on assignment of blame: socially attractive offenders are blamed less than unattractive offenders, though attractiveness did not influence perceived causation of the underlying crime. ${ }^{179}$

At least one prior study examined punishment judgments for offenders with exceptional talents. ${ }^{180}$ In an investigation of factors that may have led to the acquittal of O.J. Simpson, Paul Skolnick and Jerry Shaw tested both offender race and status to evaluate whether one or both may have contributed to that trial's outcome. ${ }^{181}$ The study tested offender status by presenting either a famous, award-winning author or an unsuccessful, poorly received author to simulated juries. Mock jurors were then asked to assign punishment. ${ }^{182}$ Analysis of the

married, and had three children. $I d$. The socially unattractive condition described the offender as a middle-aged janitor in a local office building who had held the job for only 4.5 weeks and was known to change jobs often, was not well known or liked, and was divorced (leaving three children with a prior spouse). Id.

173. Id. at $273-74$.

174. Id. at 275 .

175. Id

176. The Barnett and Field study also found no significant effect on punishment due to offender gender or race, regardless of underlying crime, though this finding has been disputed by other work. Id. But see Skolnick \& Shaw, supra note 2, at 514-15 (finding a statistically significant interaction between mock-juror race and offender race in punishment decisions).

177. Alicke \& Zell, supra note 166, at 2093-95, 2098-99.

178. Id. at 2093-95.

179. Id. at 2096

180. Skolnick \& Shaw, supra note 2, at 503.

181. Id. at 506-09.

182. Id. at 506-07. While respondents were not told that the punishment of either author would impact his future work and, in the case of the high-status offender, deprive society of 
participants' judgments showed a statistically significant three-way interaction between juror race, offender race, and offender status. ${ }^{183}$ For all combinations of juror and offender race, more responsibility for the underlying crime was attributed to low-status offenders than to high-status offenders. ${ }^{184}$

Several social scientists have looked at lay intuition regarding offender hardship. For instance, Harold Sigall and David Landy studied offender suffering in a 1972 study, which followed a more comprehensive study conducted three years earlier. ${ }^{185}$ All participants were told that an offender caused an automobile accident that killed another person, and some participants were also told that the offender lost sight in one eye before, during, or after the crime. ${ }^{186}$ The study observed a statistically significant effect on punishment judgments based upon the offender's character, but reported that the offender's suffering was not an essential part of the relationship between offender likeability and the punishment administered to him. ${ }^{187}$

Years later, William Austin revisited this issue by running numerous studies to examine the effects of offender suffering, victim suffering, and severity of underlying crime on punishment judgments. ${ }^{188}$ Offenders were described as not suffering as a result of the crime, suffering moderately, or suffering excessively (described as experiencing permanent paralysis from the neck down as a result of

highly valued artistic contributions, this omission does not appear problematic. In a real-world context, the future performance of an offender is unlikely to be known and, especially among exceptionally talented offenders, may be eclipsed by celebrity. The effects of celebrity status on criminal punishment were explored empirically in Jared Chamberlain, Monica K. Miller \& Alayna Jehle, Celebrities in the Courtroom: Legal Responses, Psychological Theory, and Empirical Research, 8 VAND. J. ENT. \& TECH. L. 551 (2006).

183. Skolnick \& Shaw, supra note 2, at 513.

184. Id.

185. Harold Sigall \& David Landy, Effects of the Defendant's Character and Suffering on Juridic Judgment: A Replication and Clarification, 88 J. Soc. PsYchoL. 149 (1972).

186. Id. at 150.

187. Id.

188. William Austin, The Concept of Desert and Its Influence on Simulated Decision Makers' Sentencing Decisions, 3 LAW \& HuM. BEHAV. 163, 169 (1979). Austin pointed to explicit invocation of Agnew's prior suffering by then-Attorney General Elliot Richardson as a justification for not imprisoning Agnew for tax fraud:

I am fully convinced that in all the circumstances leniency is justified. I am keenly aware, first of the historic magnitude of the penalties inherent in the vice president's resignation from his high office and his acceptance of a judgment of conviction for a felony. To propose that a man who has suffered these penalties should, in addition, be incarcerated . . . is more than I as head of the government's prosecuting arm, can recommend or wish.

Id. 
actions taken during the commission of the crime). ${ }^{189}$ Offender suffering reduced the assigned sentences for offenders in a pursesnatching vignette, with higher reductions observed for increased suffering. ${ }^{190}$ Less effect was observed for offender suffering, however, as the seriousness of the underlying crime increased. ${ }^{191}$ The study showed no significant difference in sentence between the no-suffering and moderate-suffering conditions for offenders guilty of more severe offenses, although a significant difference remained between sentences for the moderate- and excessive-suffering conditions. ${ }^{192}$

In a separate, concurrent study, Austin went further and tested the effects of the relevance of offender suffering on punishment. ${ }^{193}$ He varied the circumstance in which the offender was injured-either during his arrest (crime relevant) or while out on bail awaiting trial (crime irrelevant). ${ }^{194}$ Intriguingly, there was no difference in effect on sentence between crime-relevant and irrelevant suffering. ${ }^{195}$ Similarly, no change in effect was observed when the type of suffering was changed from physical injury to nonphysical suffering. ${ }^{196}$ Ultimately, Austin concluded that the participants in his study were in most cases eager to "temper justice with mercy" and reduce sentences for suffering offenders, but he noted that this "mercy" may simply be a reflection of the diminished amount of suffering an offender still deserves. ${ }^{197}$

In a later study of offender suffering, David Shaffer and others duplicated much of Austin's methodology. 198 Unlike Austin's study, however, Shaffer's study examined the differing effects of jury dogmatism (referring to the belief in a "just world" where individuals naturally receive deserved punishments) on punishment for offenders who suffered for reasons related to the crime as well as those who

189. Id. at 174 .

190. Id. at 176 .

191. Id. at 177 .

192. Id. at $177-78$.

193. Id. at 182 .

194. Id.

195. Id. Notably, the sample size was too small to achieve statistical significance.

196. Id. at 184. For nonphysical suffering, the moderate suffering condition included the offender's father suffering a minor heart attack, a suspension from the offender's job, and the offender's wife filing for divorce. Id. In the excessive suffering condition, the offender's father suffered a severe heart attack and died, the offender was fired from his job, and the offender's wife successfully divorced him and took custody of his children. Id.

197. Id. at 187.

198. David R. Shaffer, Diane Plummer \& Georgina Hammock, Hath He Suffered Enough? Effects of Jury Dogmatism, Defendant Similarity, and Defendant's Pretrial Suffering on Juridic Decisions, 50 J. PERSONALITY \& SOC. PSYCHOL. 1059 (1986). 
suffered for reasons not related to the crime. In order to test for these effects, Shaffer collected data from jurors about their personal values after receiving their verdicts and sentences. ${ }^{199}$ While Austin observed no change in sentence for "relevant" or "irrelevant" suffering, the addition of jury dogmatism data illustrated that the type of suffering does indeed affect juror's decisions-it simply does so in a symmetrical fashion based on jury dogmatism. ${ }^{200}$ Highly dogmatic juries gave reduced sentences for crime-irrelevant suffering and increased sentences for crime-relevant suffering, while low dogmatic juries did the opposite. ${ }^{201}$

While little has been done on old age in particular, ${ }^{202}$ one recent study by Christine Bergeron and Stuart McKelvie provided second-degree murder and theft vignettes to participants and informed them that the offender was either twenty, forty, or sixty years old and had been found guilty of the underlying offense. ${ }^{203}$ Participants were asked to make sentencing and parole recommendations for the offenders. ${ }^{204}$ The study found that the twenty-year-old and the sixty-year-old were treated more leniently than the forty-year-old. ${ }^{205}$ The nature of the offense, the offender's age, and the interaction between these two facts had a significant effect on punishment, ${ }^{206}$ though the effect of age differed by crime ${ }^{207}$ Bergeron and McKelvie speculated that the results indicated either bias or support for age as a "justifiable mitigating factor."208

199. Id. at $1061-62$.

200. Id. at 1063

201. Id

202. L. Beth Gaydon \& Monica K. Miller, Elders in the Justice System: How the System Treats Elders in Trials, During Imprisonment, and on Death Row, 25 BEHAV. SCI. \& L. 677, 68283 (2007) (noting the lack of research on sentences for elder offenders).

203. Christine E. Bergeron \& Stuart J. McKelvie, Effects of Defendant Age on Severity of Punishment for Different Crimes, 144 J. Soc. PsYchol. 75, 81 (2004).

204. $I d$.

205. Id. at 86 .

206. See id. at 84 (finding, among other results, that sentences were shorter for theft than for murder and were shorter for both the twenty-year-olds and sixty-year-olds than for the fortyyear-olds).

207. See id. (finding that the effect of age only produced significant differences in sentencing recommendations for murder).

208. Id. at 88 . 


\section{B. Methodology}

Our survey employed the Qualtrics survey software package. ${ }^{209}$ In the survey, subjects were presented with five different "baseline scenarios," each describing the circumstances of a hypothetical criminal offense. We developed the baseline scenarios to showcase different kinds of offenses; each of the five scenarios consisted of a simple paragraph-long narrative that focused on the offense while avoiding offender characteristics such as gender, ethnicity, or personality. These narratives, which the subjects read verbatim during the course of the survey, are set out in Table 1 below.

\section{TABLE 1. BASEline SCEnARIOS}

\begin{tabular}{|l|l|}
\hline Type & Text \\
\hline $\begin{array}{l}\text { Scenario A: } \\
\text { Theft with } \\
\text { Trespass }\end{array}$ & $\begin{array}{l}\text { John does not have all the tools he needs for his workshop but } \\
\text { knows of a family two streets over who sometimes leaves } \\
\text { unlocked the door to the detached garage next to their house. } \\
\text { When he next sees his chance, he enters the detached garage } \\
\text { through the unlocked door and takes a medium size electric drill, } \\
\text { intending to keep it forever. }\end{array}$ \\
\hline $\begin{array}{l}\text { Scenario B: } \\
\text { Injury }\end{array}$ & $\begin{array}{l}\text { Angry after overhearing another parent's remarks during a } \\
\text { soccer match in which Alex's son is playing, Alex approaches the } \\
\text { man after the game, grabs his coffee mug, knocks him down, } \\
\text { then kicks him several times while he is on the ground, knocking } \\
\text { him out for several minutes and causing cuts that require five } \\
\text { stitches. }\end{array}$ \\
\hline $\begin{array}{l}\text { Scenario C: } \\
\text { Government } \\
\text { al Corruption }\end{array}$ & $\begin{array}{l}\text { David is the mayor of a moderately sized city, and is charged } \\
\text { with deciding between competing bids for the management of a } \\
\text { youth detention facility. Company A has submitted the lowest } \\
\text { bid, and is a reputable company that provides services to } \\
\text { numerous other cities in the state. However, Company B's CEO } \\
\text { recently visited David and offered him } \$ 5,000 \text { in exchange for } \\
\text { awarding the contract to his company, which has a long record of } \\
\text { improper treatment of juveniles and has submitted a much } \\
\text { higher bid. David takes the cash and gives the job to Company B. } \\
\text { David is convicted of governmental corruption. }\end{array}$ \\
\hline
\end{tabular}

209. See QUALTRICS, http://www.qualtrics.com (last visited Mar. 9, 2011) (providing online resources for survey creation, distribution, and reporting). 


\begin{tabular}{|l|l|}
\hline Type & Text \\
\hline $\begin{array}{l}\text { Scenario D: } \\
\text { Causing } \\
\begin{array}{l}\text { Death by } \\
\text { Risk Taking }\end{array}\end{array}$ & $\begin{array}{l}\text { Two vicious pit bulls that Brian keeps for illegal dog fighting } \\
\text { have just learned to escape and have attacked a person who came } \\
\text { Brian tells the police that he will, but does not actually intend to } \\
\text { do so. The next day, the dogs escape again and maul to death a } \\
\text { man delivering a package. }\end{array}$ \\
\hline $\begin{array}{l}\text { Scenario E: } \\
\text { Intentional } \\
\text { Killing with } \\
\text { Abduction }\end{array}$ & $\begin{array}{l}\text { A woman at work reveals Mark's misdeeds to his employer, } \\
\text { thereby getting him fired. Mark devises a plan to get even with } \\
\text { point and drives her to a secluded area where he shoots her to } \\
\text { death. }\end{array}$ \\
\hline
\end{tabular}

During the survey, subjects worked with one scenario at a time. For each scenario, they were first instructed to read the scenario narrative and then were asked to report their intuitive judgments about how much punishment the offender deserved for his crimes. Subjects answered using the scale set out in Figure 1.

\section{Figure 1. Scale Used by Subjects to Assign Punishment to HYPOTHETICAL OFFENDERS}

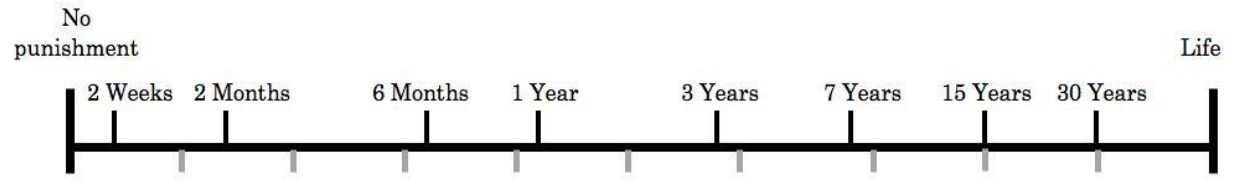

N.B.: Moving one gray dash to the right doubles punishment. Moving one gray dash to the left halves it.

After marking their judgments on this scale, subjects were given additional facts and were asked whether those facts should have any effect on the amount of punishment imposed. Subjects were shown one fact at a time, each fact corresponding to an XPF. When subjects answered "yes," they accessed the scale in Figure 1 and were instructed to indicate new punishment assignments. Baseline assignments were marked for reference.

Time markings on the scale are exponential, not linear. The hash marks below the line indicate the regular intervals of the scale, with each hash mark indicating a doubling or halving of punishment relative to the hash mark before or after it. Subjects did not have to figure out this exponential scale; they could look at the time scale 
marked above the line. Above-the-line marks correspond to grading levels typical of American criminal codes. ${ }^{210}$

The subjects' assignments of absolute liability were of little interest in this study; ${ }^{211}$ rather, the focus here was on the willingness of the respondents to adjust their original punishment assignments in light of each separate XPF. The distance between any two hash marks (or, in fact, any two equivalent distances on the scale) is always equal in relative terms, corresponding to an increase or decrease in punishment. That is, no matter where one is on the scale, one additional hash mark is equal to a doubling of punishment. Hence, intersubject comparison by change in punishment, expressed as distance traveled on the scale, is meaningful.

Our results are reported throughout as changes in respondents' exponential scale numbers ("ESNs"). For example, an ESN change of +1 reflects a doubling of punishment from that originally given in the baseline scenario, and a change of -1 constitutes a halving of punishment, while a change of +2 , by contrast, represents a quadrupling of punishment. ${ }^{212}$

TABLE 2. ESN SCALE

\begin{tabular}{|c|c|c|c|c|c|c|c|c|c|c|c|c|c|}
\hline ESN Value & -1 & -0.8 & -0.6 & -0.5 & -0.4 & -0.2 & 0 & 0.2 & 0.4 & 0.5 & 0.6 & 0.8 & 1 \\
\hline $\begin{array}{c}\text { \% Change in } \\
\text { Punishment }\end{array}$ & 50 & 57 & 66 & 71 & 76 & 87 & 100 & 115 & 132 & 141 & 152 & 174 & 200 \\
\hline
\end{tabular}

\begin{tabular}{|c|c|c|c|c|c|c|c|c|c|c|c|c|c|}
\hline ESN Value & -3 & -2.5 & -2 & -1.5 & -1 & -0.5 & 0 & 0.5 & 1 & 1.5 & 2 & 2.5 & 3 \\
\hline $\begin{array}{l}\text { \% Change in } \\
\text { Punishment }\end{array}$ & 13 & 18 & 25 & 35 & 50 & 71 & 100 & 141 & 200 & 283 & 400 & 566 & 800 \\
\hline
\end{tabular}

We constructed a series of facts that depicted the eighteen XPFs discussed in Part I. Each fact could plausibly prompt a respondent to depart from her baseline assignment of punishment. These facts are set out in Table 3.

210. Paul H. Robinson \& John M. Darley, Justice, Liability, and Blame: Community VIEWS AND THE CRIMINAL LAW (1995), available at http://www.law.upenn.edu/fac/phrobins/books/ $\mathrm{jlb} /$.

211. While perhaps agreeing on the relative blameworthiness rankings of at least "core crimes," subjects do not necessarily agree on absolute punishment levels. See Robinson \& Darley, Intuitions, supra note 3 , at 8 (proposing that empirical data refutes the assumption that people's intuitions of justice are subject to disagreement because studies have shown a broad consensus about the relative blameworthiness of different types of crimes).

212. These values were derived as follows: the relationship between years of punishment and pixel position $(\mathrm{p})$ is equal to $86.562 \times \ln (\mathrm{p})+275.587$. Using this equation, the percentage difference in punishment indicated by a distance of $d$ pixels is equal to $\mathrm{e}^{(\mathrm{d} / 86.562)}$. 
TABle 3. EXTRAlegal PUnishment FACTOR VARIATIONS

\begin{tabular}{|c|c|}
\hline XPF & Scenario Text \\
\hline \multicolumn{2}{|c|}{ A. Offender Reaction to the Offense } \\
\hline $\begin{array}{l}\text { 1. Public Acknowledgment of } \\
\text { Guilt }\end{array}$ & $\begin{array}{l}\text { During a court hearing, the offender publicly acknowledges } \\
\text { that he committed the offense, and enters a plea of guilty. }\end{array}$ \\
\hline $\begin{array}{l}\text { 2. Public Acknowledgment of } \\
\text { Guilt plus Apology }\end{array}$ & $\begin{array}{l}\text { At a hearing in court, the offender publicly acknowledges that } \\
\text { he committed the offense, enters a plea of guilty, and, on } \\
\text { advice of counsel, publicly apologizes to his victims, who are } \\
\text { present in court. }\end{array}$ \\
\hline $\begin{array}{l}\text { 3. Truly Remorseful with } \\
\text { Public Acknowledgment of } \\
\text { Guilt and Apology }\end{array}$ & $\begin{array}{l}\text { Sincerely remorseful about what he has done, the offender } \\
\text { publicly acknowledges during a court hearing that he } \\
\text { committed the offense, and pleads guilty. He publicly } \\
\text { apologizes to his victims, who are present in court. }\end{array}$ \\
\hline $\begin{array}{l}\text { 4. True Remorse, Public } \\
\text { Acknowledgment of Guilt, } \\
\text { and Apology Immediately } \\
\text { After Offense }\end{array}$ & $\begin{array}{l}\text { Soon after the offense, the offender feels sincerely remorseful. } \\
\text { While he is unable to undo his actions, he goes to his victims } \\
\text { and apologizes. He turns himself into police, even though it is } \\
\text { unlikely they would have caught him otherwise. }\end{array}$ \\
\hline \multicolumn{2}{|c|}{ B. Victim or Public Reaction to the Offense } \\
\hline 5. Forgiveness by Victim & $\begin{array}{l}\text { The victims, who are very religious people, have forgiven the } \\
\text { offender for his offense. }\end{array}$ \\
\hline $\begin{array}{l}\text { 6. Victim Wants Less or No } \\
\text { Punishment }\end{array}$ & $\begin{array}{l}\text { The victims, who are very religious people, want the offender's } \\
\text { sentence for his offense to be substantially reduced. }\end{array}$ \\
\hline $\begin{array}{l}\text { 7. Victim Wants More } \\
\text { Punishment }\end{array}$ & $\begin{array}{l}\text { The victims have expressed outrage over the offender's crime. } \\
\text { They believe a lenient sentence will trivialize the offender's } \\
\text { crime and the suffering he has caused and insist that he } \\
\text { receive more severe punishment. }\end{array}$ \\
\hline 8. Public Outrage over Offense & $\begin{array}{l}\text { After the offense, there is a good deal of news coverage about } \\
\text { the offender's actions and their effects. The public expresses } \\
\text { outrage over the offender's offense and demands that he } \\
\text { receive harsher punishment. }\end{array}$ \\
\hline \multicolumn{2}{|c|}{ C. Offender Status or Characteristics Unrelated to Commission of the Offense } \\
\hline 9. Rehabilitated & $\begin{array}{l}\text { Through his participation in a rehabilitation program, the } \\
\text { offender has come to appreciate the extent of the harm he } \\
\text { caused, has changed his view about victimizing others, and is } \\
\text { unlikely to commit a similar offense in the future. }\end{array}$ \\
\hline 10. Good Deeds Before Offense & $\begin{array}{l}\text { For a year prior to his offense, the offender volunteered nearly } \\
\text { every weekend to work at a homeless shelter and a charity } \\
\text { soup kitchen. }\end{array}$ \\
\hline 11. Good Deeds After Offense & $\begin{array}{l}\text { For the year between the offender's offense and his conviction, } \\
\text { the offender volunteers nearly every weekend at a homeless } \\
\text { shelter and a charity soup kitchen. }\end{array}$ \\
\hline
\end{tabular}




\begin{tabular}{|c|c|}
\hline $\mathrm{XPF}$ & Scenario Text \\
\hline 12. Bad Deeds or Character & $\begin{array}{l}\text { The offender is an avowed racist who has openly preached his } \\
\text { views of racial supremacy and advocated policies that promote } \\
\text { racial purity and segregation, including the prohibition of } \\
\text { mixed-race marriages. His racism played no role in his offense. }\end{array}$ \\
\hline 13. Special Talents & $\begin{array}{l}\text { The offender is a world-famous and extremely talented actor } \\
\text { who has won many awards for his work, which is known } \\
\text { particularly for touching and changing people's lives. His work } \\
\text { has not only inspired many people, but also advanced the } \\
\text { cause of art generally. Critics have marked the offender as } \\
\text { likely to have a long and stellar career. }\end{array}$ \\
\hline \multicolumn{2}{|c|}{ D. Suffering Apart from Official Punishment } \\
\hline $\begin{array}{l}\text { 14. Already Suffering as a } \\
\text { Result of the Offense }\end{array}$ & $\begin{array}{l}\text { After the offense, the offender falls during his escape. As a } \\
\text { result of his neck injuries, the offender will be paralyzed from } \\
\text { the neck down for the rest of his life. }\end{array}$ \\
\hline $\begin{array}{l}\text { 15. Has Already Paid } \\
\text { Substantial Civil } \\
\text { Compensation to the } \\
\text { Victim }\end{array}$ & $\begin{array}{l}\text { After the offender's conviction, but before his sentencing, the } \\
\text { offender is found liable for his offense in a civil lawsuit, and } \\
\text { pays his victims compensatory damages as well as special } \\
\text { damages totaling three times compensatory damages. }\end{array}$ \\
\hline $\begin{array}{l}\text { 16. Hardship for Offender's } \\
\text { Family or Others }\end{array}$ & $\begin{array}{l}\text { The offender's child has a serious disease that requires daily } \\
\text { care and attention. Because the offender's wife is dead and he } \\
\text { has no other living family, either the offender must provide } \\
\text { the care or the child will be put in state custody. The extent of } \\
\text { his punishment will affect how much care and support he can } \\
\text { give to his child. }\end{array}$ \\
\hline $\begin{array}{l}\text { 17. Hardship for Offender } \\
\text { Himself }\end{array}$ & $\begin{array}{l}\text { Several weeks after the offense, the offender is in an } \\
\text { automobile accident. As a result of neck injuries, he will be } \\
\text { paralyzed from the neck down for the rest of his life. }\end{array}$ \\
\hline 18. Old Age & $\begin{array}{l}\text { At the time of the offense, the offender is eighty years old and } \\
\text { in poor health. A person in his condition may not have long to } \\
\text { live. }\end{array}$ \\
\hline
\end{tabular}

Once subjects had the chance to revise the assignments, a new $\mathrm{XPF}$ fact was given. The instructions made clear that each of these alternative variations on the baseline scenario were to be considered independently of each other. The order in which the variations were presented was randomized. Moreover, respondents did not encounter every XPF in the study. About half of the respondents were randomly assigned to a survey that tested only the XPFs listed in Groups A and $\mathrm{D}$; the other half were randomly assigned to a survey that tested the XPFs listed in Groups B and C. Thus, every respondent considered nine punishment factors per baseline scenario. They also repeated the process for all five scenarios, for a total of forty-five variations. Additionally, each subject answered six demographic questions that 
were interspersed throughout the survey to provide a change of pace and to ensure attentiveness. On average, subjects took thirteen minutes to complete the survey.

As a quality-control measure, each survey included five questions designed to ensure that participants were paying attention. ${ }^{213}$ If subjects failed the quality-control check, all of their answers for that baseline scenario were eliminated from the data pool. However, for practical as well as empirical reasons, we did not throw out whole surveys for one failed check question. In some cases, subjects provided useful data for three or four of the scenarios but became unreliable as they reached the end of the survey. ${ }^{214}$

We were aware that a "demand effect" might have biased participants, so the instructions made it clear that a "no change" response was entirely acceptable. In fact, $71.8 \%$ of all responses were for "no change."215 Moreover, 23.3\% of the time respondents did not record a change for any XPF in a given scenario. ${ }^{216}$ With these trends in mind, there seems little reason to be concerned about a demand effect.

Data were collected from two different subject pools, which we hoped would strengthen the reliability of the results. The first data source used subjects recruited through flyers and an email listserv at the University of Chicago. Participants were brought into a quiet laboratory in downtown Chicago where they were organized into small groups (usually one to three per group). They were then brought into a computer lab where they completed the study in return for three dollars. Subjects completed the surveys individually, at their own paces. All submissions were done anonymously.

The second data collection source was a national sample available via the Internet on Amazon's Mechanical Turk. ${ }^{217}$ This

213. For example, in one of these screening questions subjects were told that the offender died before sentencing and that they should answer "No Punishment" to the scale question after marking "Yes" to the change-in-punishment question.

214. In fact, subjects failing the Scenario A check question, for example, were $30 \%$ more likely to answer "no change" to any particular question than were subjects who did not fail the check. Because answering more questions with "no change" reduces the length of the survey (selecting "no change" for all questions would reduce the length of the survey by half because the subject is then presented with no scale questions), we can assume that subjects failing the quality-control check questions were attempting to quickly finish the survey. However, this would not impugn their earlier answers for which they did not fail the check question.

215. Out of 16,749 recorded responses, 12,018 were "no change" (71.8\%).

216. Counting each scenario separately, respondents ran through a set of XPF questions 1,861 times. Respondents did not record any change to their initial punishment assignment 434 times (23.3\%).

217. See generally Welcome, AMAZON Mechanical TURK (Mar. 9, 2011), http://www. mturk.com/mturk/welcome (advertising Mechanical Turk as a marketplace for businesses and 
system coordinates a large pool of paid volunteers who perform tasks over the Internet (including many other tasks besides surveys) for a wide range of "requesters." In this study, subjects recruited through Mechanical Turk were paid $\$ 1.60$ for completing the survey. The Qualtrics survey program mirrored the program employed in Chicago, though due to the nature of Mechanical Turk, participants could take the survey on their own personal computers. Submissions here were also kept anonymous. In general, our data show consistency across the two subject pools. ${ }^{218}$

The combined subject pool of 423 people (173 from Chicago and 250 from Mechanical Turk) displayed a broad range of demographics. Women comprised $58.6 \%$ of the pool and $75.3 \%$ of subjects were unmarried, divorced, or separated. Whites made up $66.9 \%$ of the sample, while $17.4 \%$ of the participants were black, $6.6 \%$ were Asian, and $4.3 \%$ were Latino. The remaining $4.5 \%$ consisted of other ethnic groups. The average subject's age was 29.6 years old, varying by a standard deviation of 11.4 years; the minimum age allowed was 18 . Additionally, most subjects had completed some college or had obtained a two- or four-year degree (36.6\%, $11.4 \%$, and $25.2 \%$, respectively); $12.1 \%$ had either a high school degree or no degree, while $14.8 \%$ had an advanced graduate degree. Average income was $\$ 52,262$, with a standard deviation of $\$ 34,588$.

Once data collection was completed, we computed two values. The first, which we refer to as "XPF popularity," is the percentage of respondents that changed their initial punishment assignment in light of the XPF in question. The second, which we refer to as "XPF magnitude," is the amount by which respondents on average altered their initial punishment assignment. We calculated XPF magnitude based on the ESNs reported in the survey, with a response of "no change" averaged into the value as $0 .{ }^{219}$ Whenever an XPF magnitude value is reported, a negative ESN connotes mitigation in punishment and a positive ESN connotes an aggravation of punishment. ${ }^{220}$

\footnotetext{
developers to access a workforce for thousands of individual tasks). Researchers who have studied Amazon's Mechanical Turk system have found that American Mechanical Turk participants on average bear a close resemblance to the U.S. population at large. See Michael Buhrmester et al., Amazon's Mechanical Turk: A New Source of Inexpensive, Yet High-Quality, Data? 6 PERSP. ON PSYCHOL. SCI. 3, 4 (2011) (suggesting that Mechanical Turk participants are more demographically diverse than standard internet samples).

218. See infra Part II.F (evaluating the impact of several variables on XPF popularity).

219. See supra note 210 and accompanying text.

220. Note that three of the eighteen XPFs were designed to be aggravators: XPF 7 ("Victim Wants More Punishment"), XPF 8 ("Public Outrage over Offense"), and XPF 12 ("Bad Deeds or Character").
} 


\section{Support for Adjusting Punishment in Light of Extralegal Punishment Factors}

Table 4 reports the average punishment given for each baseline scenario (in other words, without consideration of any XPF), with the ESN-scale value translated into a term of imprisonment as it appeared on the survey's punishment scale.

\section{Table 4. Average Punishment for Each Baseline Scenario}

\begin{tabular}{|l|c|c|c|c|c|c|}
\hline Scenarios: & $\begin{array}{c}\text { A. } \\
\text { Theft with } \\
\text { Trespass }\end{array}$ & $\begin{array}{c}\text { B. } \\
\text { Personal } \\
\text { Injury }\end{array}$ & $\begin{array}{c}\text { C. } \\
\text { Govern- } \\
\text { mental } \\
\text { Corruption }\end{array}$ & $\begin{array}{c}\text { D. } \\
\text { Causing } \\
\text { Death by } \\
\text { Risk } \\
\text { Taking }\end{array}$ & $\begin{array}{c}\text { E. } \\
\text { Intentional } \\
\text { Killing and } \\
\text { Abduction }\end{array}$ & $\begin{array}{c}\text { Average } \\
\text { for All } \\
\text { Baseline } \\
\text { Scenarios }\end{array}$ \\
\hline $\begin{array}{l}\text { Prison } \\
\text { Term in } \\
\text { Years }\end{array}$ & 1.0 & 1.3 & 6.1 & 14.2 & 49.7 & 14.5 \\
\hline
\end{tabular}

Table 5 presents the results of the changes in punishment for each XPF in each baseline scenario. The value in the top row within each cell displays XPF popularity of each XPF in each baseline scenario. The value in the bottom row of each cell reports the XPF magnitude of each XPF in each baseline scenario. Summary figures for each XPF across all scenarios are shown at the end of each row. ${ }^{221}$ Summary figures for each baseline scenario across all XPFs are reported at the bottom of each column. ${ }^{222}$ The bottom-right cell shows averages for all recorded data points.

221. "Row Averages" denotes (1) the percentage of responses that displayed a change in punishment amount for each XPF across all scenarios, and (2) the average ESN value among all responses to each XPF for all scenarios.

222. For each scenario, "Column Averages" denotes (1) the percentage of responses that displayed a change in punishment amount after the respondent was shown each XPF, and (2) the average ESN value recorded after the respondent was shown each XPF. 
TABle 5. XPF PopUlarity AND MAGNitude, ORDERED BY OVERALL POPULARITY

\begin{tabular}{|c|c|c|c|c|c|c|}
\hline \multirow[b]{2}{*}{ XPFs } & \multicolumn{6}{|c|}{ Scenarios } \\
\hline & $\begin{array}{c}\text { A. } \\
\text { Theft with } \\
\text { Trespass }\end{array}$ & $\begin{array}{c}\text { B. } \\
\text { Personal } \\
\text { Injury }\end{array}$ & $\begin{array}{c}\text { C. } \\
\text { Governmental } \\
\text { Corruption }\end{array}$ & $\begin{array}{c}\text { D. } \\
\text { Causing } \\
\text { Death by } \\
\text { Risk Taking }\end{array}$ & $\begin{array}{c}\text { E. } \\
\text { Intentional } \\
\text { Killing and } \\
\text { Abduction }\end{array}$ & $\begin{array}{c}\text { Row } \\
\text { Averages }\end{array}$ \\
\hline $\begin{array}{l}\text { 4. True Remorse, } \\
\text { Acknowledgment of Guilt, and } \\
\text { Apology Immediately After } \\
\text { Offense }\end{array}$ & $\begin{array}{c}76.9 \% \\
-0.94\end{array}$ & $\begin{array}{c}65.6 \% \\
-0.66\end{array}$ & $\begin{array}{l}70.8 \% \\
-1.15\end{array}$ & $\begin{array}{l}48.7 \% \\
-0.51\end{array}$ & $\begin{array}{l}40.1 \% \\
-0.33\end{array}$ & $\begin{array}{c}60.5 \% \\
-0.72\end{array}$ \\
\hline 9. Rehabilitated & $\begin{array}{l}52.5 \% \\
-0.32\end{array}$ & $\begin{array}{l}51.4 \% \\
-0.26\end{array}$ & $\begin{array}{l}41.8 \% \\
-0.29\end{array}$ & $\begin{array}{l}42.9 \% \\
-0.32\end{array}$ & $\begin{array}{l}30.9 \% \\
-0.26\end{array}$ & $\begin{array}{l}44.0 \% \\
-0.29\end{array}$ \\
\hline $\begin{array}{l}\text { 15. Has Already Paid } \\
\text { Substantial Civil Compensation } \\
\text { to the Victim }\end{array}$ & $\begin{array}{c}64.6 \% \\
-0.88\end{array}$ & $\begin{array}{l}53.3 \% \\
-0.62\end{array}$ & $\begin{array}{l}44.3 \% \\
-0.68\end{array}$ & $\begin{array}{c}28.4 \% \\
-0.24\end{array}$ & $\begin{array}{l}14.1 \% \\
-0.04\end{array}$ & $\begin{array}{l}41.0 \% \\
-0.49\end{array}$ \\
\hline $\begin{array}{l}\text { 3. Truly Remorseful with Public } \\
\text { Acknowledgment of Guilt and } \\
\text { Apology }\end{array}$ & $\begin{array}{l}52.3 \% \\
-0.42\end{array}$ & $\begin{array}{l}47.7 \% \\
-0.36\end{array}$ & $\begin{array}{l}37.9 \% \\
-0.37\end{array}$ & $\begin{array}{c}28.4 \% \\
-0.21\end{array}$ & $\begin{array}{c}20.8 \% \\
-0.11\end{array}$ & $\begin{array}{l}37.5 \% \\
-0.29\end{array}$ \\
\hline $\begin{array}{l}\text { 16. Hardship for Offender's } \\
\text { Family or Others }\end{array}$ & $\begin{array}{l}50.3 \% \\
-0.68\end{array}$ & $\begin{array}{l}51.3 \% \\
-0.63\end{array}$ & $\begin{array}{c}40.5 \% \\
-0.77\end{array}$ & $\begin{array}{c}28.9 \% \\
-0.53\end{array}$ & $\begin{array}{l}8.3 \% \\
-0.09\end{array}$ & $\begin{array}{c}35.9 \% \\
-0.54\end{array}$ \\
\hline $\begin{array}{l}\text { 14. Already Suffering from His } \\
\text { Offense }\end{array}$ & $\begin{array}{l}46.2 \% \\
-0.76\end{array}$ & $\begin{array}{c}37.4 \% \\
-0.37\end{array}$ & $\begin{array}{c}28.2 \% \\
-0.49\end{array}$ & $\begin{array}{c}39.6 \% \\
-0.81\end{array}$ & $\begin{array}{l}14.1 \% \\
-0.36\end{array}$ & $\begin{array}{l}33.2 \% \\
-0.56\end{array}$ \\
\hline $\begin{array}{l}\text { 2. Public Acknowledgment of } \\
\text { Guilt plus Apology }\end{array}$ & $\begin{array}{l}44.6 \% \\
-0.39\end{array}$ & $\begin{array}{l}42.1 \% \\
-0.29\end{array}$ & $\begin{array}{c}29.7 \% \\
-0.24\end{array}$ & $\begin{array}{c}20.3 \% \\
-0.14\end{array}$ & $\begin{array}{c}14.6 \% \\
-0.04\end{array}$ & $\begin{array}{l}30.3 \% \\
-0.22\end{array}$ \\
\hline $\begin{array}{l}\text { 17. Hardship for Offender } \\
\text { Himself }\end{array}$ & $\begin{array}{l}45.1 \% \\
-0.67 \\
\end{array}$ & $\begin{array}{c}31.3 \% \\
-0.48 \\
\end{array}$ & $\begin{array}{c}26.7 \% \\
-0.76 \\
\end{array}$ & $\begin{array}{c}23.9 \% \\
-0.53 \\
\end{array}$ & $\begin{array}{c}13.0 \% \\
-0.37 \\
\end{array}$ & $\begin{array}{c}28.0 \% \\
-0.56 \\
\end{array}$ \\
\hline $\begin{array}{l}\text { 6. Victim Wants Less or No } \\
\text { Punishment }\end{array}$ & $\begin{array}{c}39.7 \% \\
-0.28\end{array}$ & $\begin{array}{c}32.4 \% \\
-0.21\end{array}$ & $\begin{array}{c}16.4 \% \\
-0.20\end{array}$ & $\begin{array}{c}24.9 \% \\
-0.27\end{array}$ & $\begin{array}{c}18.9 \% \\
-0.15\end{array}$ & $\begin{array}{c}26.5 \% \\
-0.22\end{array}$ \\
\hline $\begin{array}{l}\text { 1. Public Acknowledgment of } \\
\text { Guilt }\end{array}$ & $\begin{array}{l}32.3 \% \\
-0.20\end{array}$ & $\begin{array}{c}35.2 \% \\
-0.19\end{array}$ & $\begin{array}{c}25.6 \% \\
-0.20\end{array}$ & $\begin{array}{c}21.8 \% \\
-0.15\end{array}$ & $\begin{array}{l}15.6 \% \\
-0.05\end{array}$ & $\begin{array}{c}26.2 \% \\
-0.16\end{array}$ \\
\hline 18. Old Age & $\begin{array}{c}32.8 \% \\
-0.33 \\
\end{array}$ & $\begin{array}{c}26.2 \% \\
-0.34 \\
\end{array}$ & $\begin{array}{c}21.5 \% \\
-0.35\end{array}$ & $\begin{array}{c}20.8 \% \\
-0.41\end{array}$ & $\begin{array}{l}9.9 \% \\
-0.12 \\
\end{array}$ & $\begin{array}{c}22.3 \% \\
-0.31\end{array}$ \\
\hline $\begin{array}{l}\text { 7. Victim Wants More } \\
\text { Punishment }\end{array}$ & $\begin{array}{l}19.6 \% \\
+0.09\end{array}$ & $\begin{array}{l}19.0 \% \\
+0.11\end{array}$ & $\begin{array}{l}24.9 \% \\
+0.05\end{array}$ & $\begin{array}{l}23.2 \% \\
+0.07\end{array}$ & $\begin{array}{l}15.4 \% \\
+0.00\end{array}$ & $\begin{array}{l}20.4 \% \\
+0.06\end{array}$ \\
\hline 11. Good Deeds After Offense & $\begin{array}{c}25.7 \% \\
-0.16 \\
\end{array}$ & $\begin{array}{c}29.1 \% \\
-0.14 \\
\end{array}$ & $\begin{array}{c}16.4 \% \\
-0.12 \\
\end{array}$ & $\begin{array}{c}16.9 \% \\
-0.09 \\
\end{array}$ & $\begin{array}{l}9.7 \% \\
-0.05 \\
\end{array}$ & $\begin{array}{c}19.6 \% \\
-0.11 \\
\end{array}$ \\
\hline 5. Forgiveness by Victim & $\begin{array}{l}31.3 \% \\
-0.25 \\
\end{array}$ & $\begin{array}{c}22.5 \% \\
-0.29 \\
\end{array}$ & $\begin{array}{l}13.0 \% \\
-0.07 \\
\end{array}$ & $\begin{array}{c}16.4 \% \\
-0.19 \\
\end{array}$ & $\begin{array}{l}12.0 \% \\
-0.10 \\
\end{array}$ & $\begin{array}{c}19.1 \% \\
-0.18 \\
\end{array}$ \\
\hline 12. Bad Deeds or Character & $\begin{array}{l}14.0 \% \\
+0.04\end{array}$ & $\begin{array}{l}20.7 \% \\
+0.15\end{array}$ & $\begin{array}{l}19.8 \% \\
+0.01\end{array}$ & $\begin{array}{l}15.8 \% \\
+0.04\end{array}$ & $\begin{array}{l}14.9 \% \\
+0.01\end{array}$ & $\begin{array}{l}17.0 \% \\
+0.05\end{array}$ \\
\hline 8. Public Outrage over Offense & $\begin{array}{l}16.2 \% \\
+0.09 \\
\end{array}$ & $\begin{array}{l}17.3 \% \\
+0.06 \\
\end{array}$ & $\begin{array}{l}16.9 \% \\
+0.00 \\
\end{array}$ & $\begin{array}{l}14.7 \% \\
+0.16 \\
\end{array}$ & $\begin{array}{l}12.6 \% \\
-0.03 \\
\end{array}$ & $\begin{array}{l}15.6 \% \\
+0.05 \\
\end{array}$ \\
\hline 10. Good Deeds Before Offense & $\begin{array}{c}20.1 \% \\
-0.08 \\
\end{array}$ & $\begin{array}{c}20.1 \% \\
-0.11 \\
\end{array}$ & $\begin{array}{c}15.2 \% \\
-0.18 \\
\end{array}$ & $\begin{array}{l}11.9 \% \\
-0.05 \\
\end{array}$ & $\begin{array}{r}7.4 \% \\
-0.04 \\
\end{array}$ & $\begin{array}{c}15.0 \% \\
-0.07 \\
\end{array}$ \\
\hline 13. Special Talents & $\begin{array}{l}14.0 \% \\
+0.12 \\
\end{array}$ & $\begin{array}{l}12.3 \% \\
+0.03 \\
\end{array}$ & $\begin{array}{c}10.7 \% \\
-0.02 \\
\end{array}$ & $\begin{array}{l}10.2 \% \\
+0.02\end{array}$ & $\begin{array}{l}5.7 \% \\
-0.03 \\
\end{array}$ & $\begin{array}{l}10.6 \% \\
+0.02\end{array}$ \\
\hline Column Averages & $\begin{array}{c}37.7 \% \\
-0.33 \\
\end{array}$ & $\begin{array}{c}34.2 \% \\
-0.26\end{array}$ & $\begin{array}{c}27.8 \% \\
-0.32\end{array}$ & $\begin{array}{c}24.3 \% \\
-0.23\end{array}$ & $\begin{array}{c}15.4 \% \\
-0.12 \\
\end{array}$ & $\begin{array}{c}27.9 \% \\
-0.25 \\
\end{array}$ \\
\hline
\end{tabular}

N.B.: XPF popularity values significantly greater than $50 \%$ (i.e., above the margin of error)—-thereby enjoying significant majority support-are bolded and italicized. Popularity values at least within the margin of error are italicized. 
Table 6 , organized in the same way as Table 5 , gives in each cell the mean ESN change among those participants who adjusted punishment. In other words, we recalculated XPF magnitude values so as to include only nonzero responses. As with Table 5, a negative value means mitigation in punishment and a positive value means aggravation in punishment.

\section{TABle 6. MeAN ESN ChANGES AMONG SUbJECTS} Who AdJUSTED PUNISHMENT

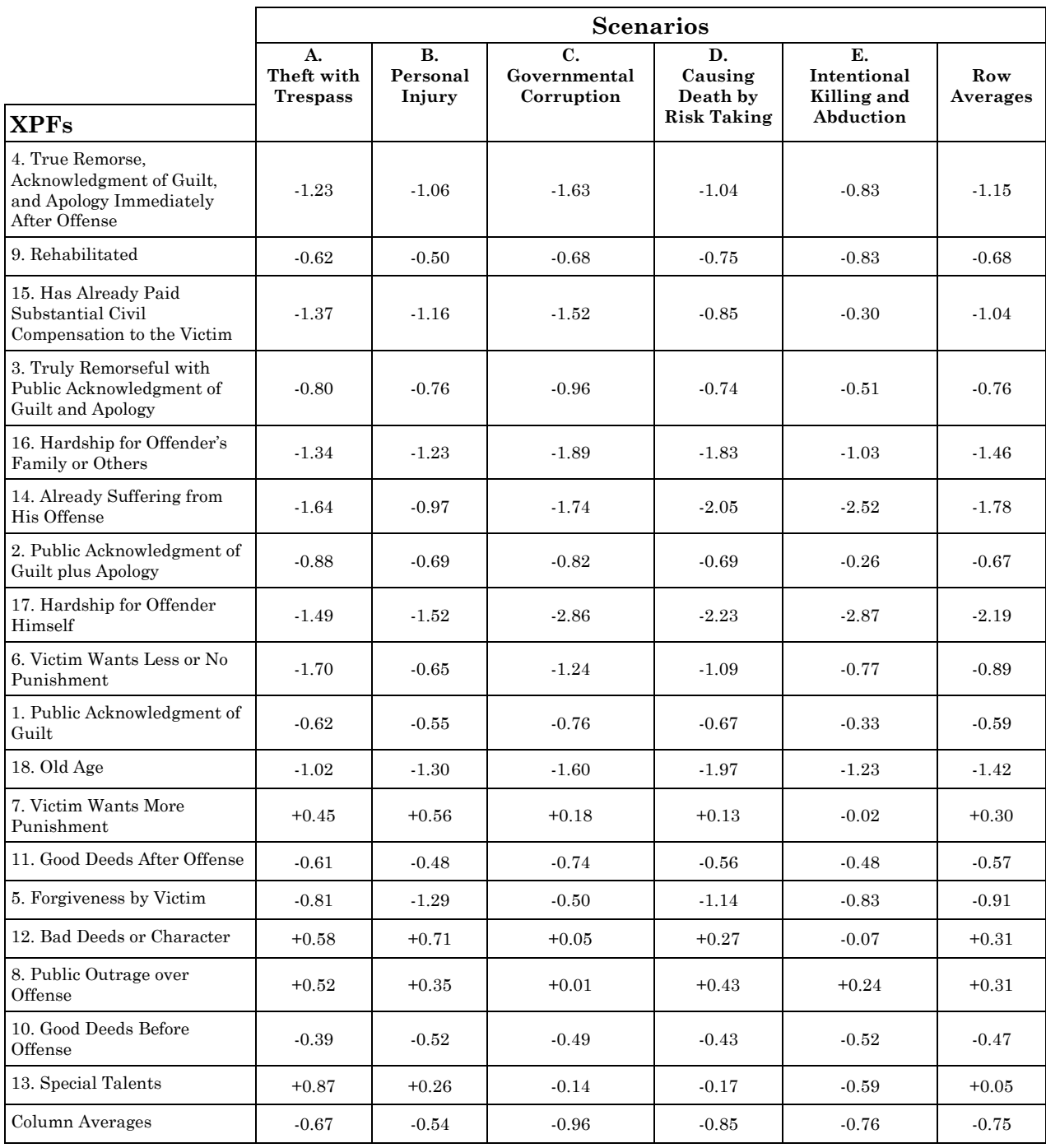

The histogram in Figure 2 shows the distribution of ESN values from all recorded responses. An overwhelming $71.8 \%$ of 
responses indicated "no change" and were recorded as 0 . The remaining $27.9 \%$ of responses were between +10 and -10 , with the responses having a negatively skewed unimodal distribution centered on 0 . Since only a few XPFs aggravated punishment, ${ }^{223}$ most ESN values recorded were negative. ${ }^{224}$

Figure 2. FREQUENCY OF XPF AdJUSTMENT AMOUNTS

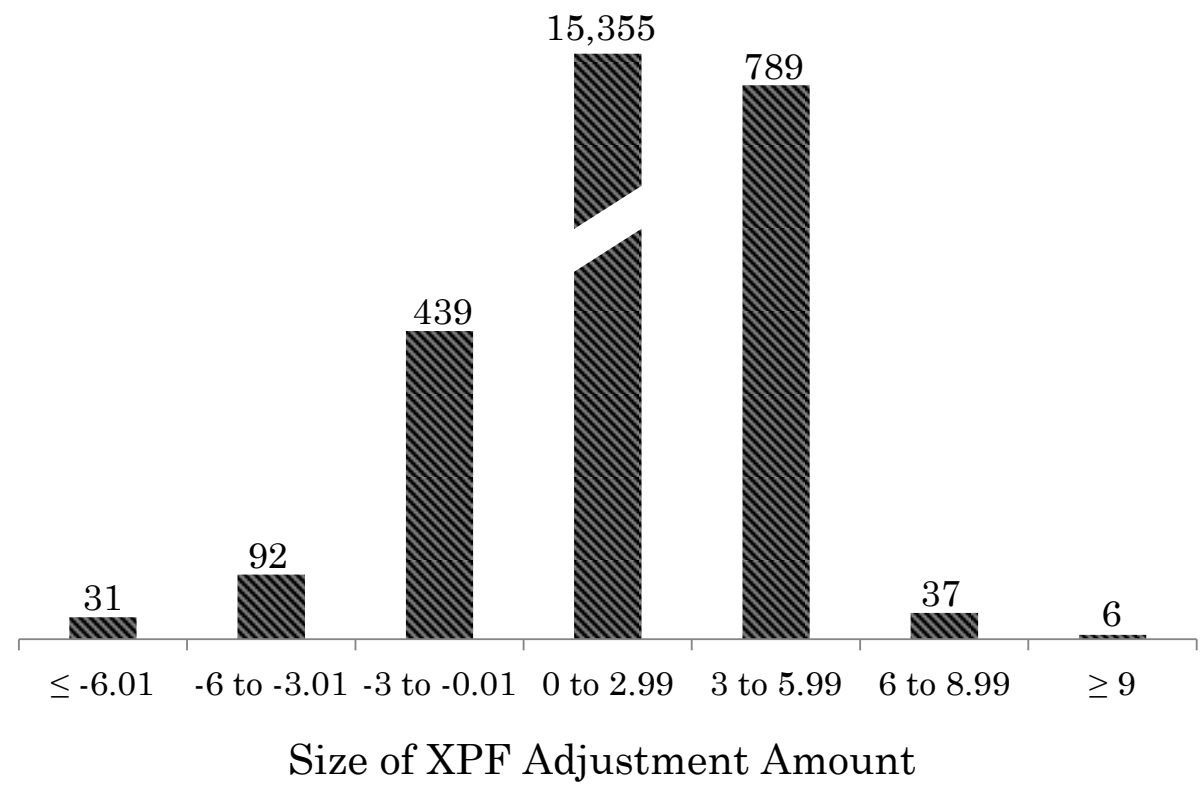

In broadest outline, Table 5 suggests that there is indeed support among lay people for punishment factors that have traditionally been excluded from the criminal law's liability and punishment rules. Every XPF tested had some support, even in relation to Scenario E ("Intentional Killing and Abduction"), the most serious offense. A number of XPFs enjoyed the support of a majority of study participants (those italicized in Table 5), with support reaching as high as $77 \%$ for one XPF. ${ }^{225}$

It is equally true, however, that most XPFs do not have majority support, even in Scenario A, which sets out the least serious offense in the survey. In Scenario A, half of the XPFs had the support

223. XPFs 7, 8, and 12 were designed to be aggravators, and XPF 13 ("Special Talents") turned out to be one as well.

224. Individual histograms for each offense and XPF variation are on file with author.

225. XPF 4 under Scenario A. 
of less than a third of the participants. ${ }^{226}$ Although as many as eight XPFs may have enjoyed majority support, if the margin of error is taken into account, only two unquestionably did. ${ }^{227}$ Scenario A, in fact, was unlike other scenarios in this regard: only in two other instances did an XPF command clear majority support. ${ }^{228}$ For Scenario E, the most serious offense, only one XPF received the support of even a third of study participants. ${ }^{229}$

\section{Effect of Baseline Offense on XPF Adjustments to Punishment}

The results suggest that XPF popularity and XPF magnitude depend on the underlying offense at issue. The differences among columns, including the column averages in the bottom row of Tables 5 and 6, show that both XPF popularity and magnitude decrease substantially as the seriousness of the offense increases. ${ }^{230}$ Across all XPFs, popularity drops from $38 \%$ in Scenario A to $15 \%$ in Scenario E, reflecting a decline in support by more than half. In most instances, the drop in popularity moves in a consistently downward progression across the five baseline offenses as seriousness increases.

But this "offense effect" is not consistent for all XPFs. Popularity for some of the least popular XPFs remains at the same low level across all offenses. ${ }^{231}$ Some XPFs show a drop-off in popularity of only a third, ${ }^{232}$ while two relatively popular XPFs exhibit a decline in popularity of only a fifth. ${ }^{233}$ This inconsistency in the way in which

226. See supra Column A (displaying the popularity of each XPF in the "Theft with Trespass" scenario).

227. XPF 4 ("True Remorse, Acknowledgment of Guilt, and Apology Immediately after Offense") and XPF 15 ("Has Already Paid Substantial Civil Compensation to the Victim").

228. XPF 4 in Scenarios B and C. See supra Table 5, Columns B-C (displaying the popularity of XPF 4 in "Personal Injury" and "Governmental Corruption" scenarios).

229. See id. Column E (reporting that $40.1 \%$ of participants supported XPF 4).

230. But notice that this is not necessarily true of XPF magnitude if all zero values are excluded. Consider the "Column Averages" row in Table 6. If one considers just those who actually adjusted punishment, the amount of that adjustment is different for different baseline scenarios but is not directly related to the seriousness of the offense.

231. This is true for XPF 7 ("Victim Wants More Punishment"), XPF 8 ("Public Outrage over Offense"), and XPF 12 ("Bad Deeds or Character"). See supra Table 5 (illustrating consistent, low popularity).

232. This occurs with several XPFs: the unpopular XPF 13 ("Special Talents"), the moderately popular XPF 2 ("Public Acknowledgment of Guilt and Apology without Remorse"), XPF 4 ("True Remorse, Acknowledgment of Guilt, and Apology Immediately After Offense"), XPF 11 ("Good Deeds After Offense"), XPF 17 ("Hardship for Offender Himself"), and XPF 18 ("Old Age"). See id. (illustrating the drop-off in popularity).

233. This occurs with two relatively popular XPFs: XPF 15 ("Has Already Paid Civil Compensation") and XPF 16 ("Hardship for Offender's Family or Others"). See id. (illustrating the drop off in popularity). 
popularity declines as offense seriousness increases suggests that the interaction between the XPF and the underlying offense is quite complex and is more than just a reflection of a punishment factor's initial popularity. ${ }^{234}$

In addition to XPF popularity, XPF magnitude is similarly affected by switching among baseline scenarios. In Table 7 below, we list XPF magnitude by scenario (taken from the lower half of each cell in Table 5), but this time we include additional information about whether the figures in any row are significantly different from one another-that is, whether the magnitude of an XPF for a given offense differs significantly from the magnitude of the same XPF for a different offense.

To test whether the magnitude of each XPF is affected by the baseline scenario to which it is paired, we conducted an analysis of variance (ANOVA) for each XPF. The ANOVA examines whether there are statistically significant differences among a series of distributions. ${ }^{235}$ If the analysis yields an $\mathrm{F}$ value that is sufficiently high, we may conclude that the values within the row are significantly different from one another. The rows have been bolded where this is the case. A post hoc analysis using the Scheffé method reveals which figures in the row are statistically different from which other figures. If two roman numerals in the same row differ, the ESN adjustments for those scenarios are significantly different from one another. ${ }^{236}$ For example, for XPF 4, Scenario A is significantly different from Scenario $\mathrm{D}$, as indicated by the absence of any roman numeral in common between them. But for the same XPF, Scenarios A and B are not significantly different, as indicated by the presence of a roman numeral in both cells, nor are Scenarios A and C, B and D, and D and E.

234. Indeed, the finding of this sort of complex interactive effect between XPF and offense is consistent with previous studies suggesting that lay intuitions regarding proper punishment are quite nuanced and sophisticated and take account of a wide range of interacting factors. See, e.g., Robinson \& DARLEY, supra note 210, at 139-47; Paul H. Robinson \& Robert Kurzban, Concordance and Conflict in Intuitions of Justice, 91 MiNn. L. REV. 1829, 1846 (2007) ("The conclusion suggested by the empirical evidence is that people take account of a wide variety of factors and often give them quite different effect in different situations. That is, people's intuitions of justice are not vague or simplistic, as claimed, but rather sophisticated and complex.").

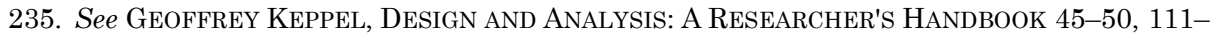
12 (3d ed. 1991) (describing the F statistic and ANOVA).

236. See id. at 172-73 (describing the Scheffé method). 
TABLE 7. EFFECTS OF BASELINE CRIME SCENARIO ON XPF MAGNITUDE

\begin{tabular}{|c|c|c|c|c|c|}
\hline \multirow[b]{2}{*}{ XPFs } & \multicolumn{5}{|c|}{ Scenarios } \\
\hline & $\begin{array}{c}\text { A. } \\
\text { Theft with } \\
\text { Trespass }\end{array}$ & $\begin{array}{c}\text { B. } \\
\text { Personal } \\
\text { Injury }\end{array}$ & $\begin{array}{c}\text { C. } \\
\text { Governmental } \\
\text { Corruption }\end{array}$ & \begin{tabular}{|c|} 
D. \\
Causing Death by \\
Risk Taking
\end{tabular} & $\begin{array}{c}\text { E. } \\
\begin{array}{c}\text { Intentional Killing } \\
\text { and Abduction }\end{array}\end{array}$ \\
\hline $\begin{array}{l}\text { 4. True Remorse, Acknowledgment } \\
\text { of Guilt, and Apology Immediately } \\
\text { After Offense }\end{array}$ & $-0.94 \mathrm{i}, \mathrm{ii}$ & $-0.666_{\mathrm{ii}}$,iii & $-1.15 i$ & -0.51 iii, iv & -0.33 iv \\
\hline 9. Rehabilitated & -0.32 & -0.26 & -0.29 & -0.32 & -0.26 \\
\hline $\begin{array}{l}\text { 15. Has Already Paid Substantial } \\
\text { Civil Compensation to the Victim }\end{array}$ & $-0.88_{i}$ & $-0.62 i$ & $-0.68_{i}$ & -0.24 ii & -0.04 ii \\
\hline $\begin{array}{l}\text { 3. Truly Remorseful with Public } \\
\text { Acknowledgment of Guilt and } \\
\text { Apology }\end{array}$ & $-0.42_{i}$ & $-0.36_{i}$ & $-0.37_{i}$ & $-0.21_{i, \mathrm{ii}}$ & $-0.11_{\text {ii }}$ \\
\hline $\begin{array}{l}\text { 16. Hardship for Offender's Family } \\
\text { or Others }\end{array}$ & $-0.68_{i}$ & $-0.63_{i}$ & $-0.77_{i}$ & $-0.533_{i}$ & $-0.09_{\mathrm{ii}}$ \\
\hline $\begin{array}{l}\text { 14. Already Suffering from His } \\
\text { Offense }\end{array}$ & -0.76 & -0.37 & -0.49 & -0.81 & -0.36 \\
\hline $\begin{array}{l}\text { 2. Public Acknowledgment of Guilt } \\
\text { plus Apology }\end{array}$ & $-0.39_{i}$ & $-0.29_{\mathrm{i}, \mathrm{ii}}$ & $-0.24 \mathrm{i}, \mathrm{ii}, \mathrm{iii}$ & $-0.14 \mathrm{ii}, \mathrm{iii}$ & $-0.04 \mathrm{iii}$ \\
\hline 17. Hardship for Offender Himself & -0.67 & -0.48 & -0.76 & -0.53 & -0.37 \\
\hline $\begin{array}{l}\text { 6. Victim Wants Less or No } \\
\text { Punishment }\end{array}$ & -0.28 & -0.21 & -0.20 & -0.27 & -0.15 \\
\hline 1. Public Acknowledgment of Guilt & -0.20 & -0.19 & -0.20 & -0.15 & -0.05 \\
\hline 18. Old Age & -0.33 & -0.34 & -0.35 & -0.40 & -0.12 \\
\hline 7. Victim Wants More Punishment & +0.09 & +0.11 & +0.05 & +0.07 & +0.00 \\
\hline 11. Good Deeds After Offense & -0.16 & -0.14 & -0.12 & -0.09 & -0.05 \\
\hline 5. Forgiveness by Victim & -0.25 & -0.29 & -0.07 & -0.19 & -0.10 \\
\hline 12. Bad Deeds or Character & +0.04 & +0.15 & +0.01 & +0.04 & +0.01 \\
\hline 8. Public Outrage over Offense & +0.09 & +0.06 & +0.00 & +0.16 & -0.03 \\
\hline 10. Good Deeds Before Offense & -0.08 & -0.11 & -0.18 & -0.05 & -0.04 \\
\hline 13. Special Talents & +0.12 & +0.03 & -0.02 & +0.02 & -0.03 \\
\hline Column Averages & $-0.33_{i}$ & $-0.26_{\mathrm{ii}, \mathrm{iii}}$ & $-0.32_{\mathrm{i}, \mathrm{ii}}$ & $-0.23_{\mathrm{iii}}$ & $-0.12_{\text {iv }}$ \\
\hline
\end{tabular}

N.B.: Rows are bolded when the null hypothesis of no difference among scenarios may be rejected at the $\mathrm{p}<0.05$ level.

Again, Table 7 shows that there is a complex interactive effect between a punishment factor and the underlying offense. For example, the magnitude of XPF 15 ("Has Already Paid Substantial Civil Compensation to the Victim") displayed in Scenarios A, B, and C diminished considerably in Scenarios D and E. ${ }^{237}$ XPF 9 ("Rehabilitated") displayed a different tendency: the factor's 
magnitude remained consistent across all scenarios. ${ }^{238}$ Interestingly, XPF magnitude does not always depend on the seriousness of the underlying offense. For example, XPF 4 ("True Remorse, Acknowledgment of Guilt, and Apology Immediately After Offense") displayed greater magnitude when applied to Scenario $\mathrm{C}$ than when applied to Scenario B, ${ }^{239}$ even though Scenario C was considered the more serious offense. ${ }^{240}$

\section{E. Relative Relation Among XPFs by Popularity}

Table 8 below presents in each column the relative popularity of each XPF. XPFs are ranked according to their popularity, or, in other words, by the percentage of subjects who indicated that the factor should affect the baseline punishment assignment. XPFs are ordered according to their overall support, as provided in Table 5 above.

The relative popularity of an XPF varies depending on the baseline offense. This is itself no surprise. Subsection $\mathrm{C}$ has shown that there is some interactive effect between XPF popularity and offense. More surprising is that there is some general consistency in $\mathrm{XPF}$ ranking across the different kinds of offenses. XPFs that have a low relative rank for one scenario commonly have a similarly low rank for other scenarios; XPFs that have a high relative rank for one kind of offense tend to maintain that approximate ranking for other offenses. Such consistency is found in XPFs at all ranges of popularity. For example, XPF 13 ("Special Talents") ranks as the XPF with the least popularity for all five scenarios. ${ }^{241}$ Likewise, XPF 2 ("Public Acknowledgment of Guilt plus Apology") varies only slightly in rank, from 6 th to 12 th among the baseline scenarios. ${ }^{242}$

238. $I d$.

239. $I d$.

240. See supra Table 4 (reporting the average punishment given for each baseline scenario, without consideration of any XPF).

241. See supra Table 8 (ranking XPF 13 as $18-18-18-18-18$ ). Similarly, XPF 10 ("Good Deeds Before Offense") ranks fourteenth or fifteenth for the nonhomicide offenses and seventeenth for the homicide offenses. $I d$.

242. See id. (ranking XPF 2 as $8-6-6-12-8$ ). 
TABLE 8. RANK BY POPUlaRITY OF XPFs FOR EACH SCENARIO

\begin{tabular}{|c|c|c|c|c|c|c|}
\hline \multirow[b]{2}{*}{ XPFs } & \multicolumn{6}{|c|}{ Scenarios } \\
\hline & $\begin{array}{c}\text { A. } \\
\text { Theft with } \\
\text { Trespass }\end{array}$ & $\begin{array}{c}\text { B. } \\
\text { Personal } \\
\text { Injury }\end{array}$ & $\begin{array}{c}\text { C. } \\
\text { Governmental } \\
\text { Corruption }\end{array}$ & $\begin{array}{c}\text { D. } \\
\text { Causing } \\
\text { Death by } \\
\text { Risk Taking }\end{array}$ & $\begin{array}{c}\text { E. } \\
\text { Intentional } \\
\text { Killing and } \\
\text { Abduction }\end{array}$ & $\begin{array}{c}\text { Row } \\
\text { Averages }\end{array}$ \\
\hline $\begin{array}{l}\text { 4. True Remorse, } \\
\text { Acknowledgment of Guilt and } \\
\text { Apology Immediately After } \\
\text { Offense }\end{array}$ & $\begin{array}{c}1 \\
(77 \%)\end{array}$ & $\begin{array}{c}1 \\
(66 \%)\end{array}$ & $\begin{array}{c}1 \\
(71 \%)\end{array}$ & $\begin{array}{c}1 \\
(49 \%)\end{array}$ & $\begin{array}{c}1 \\
(40 \%)\end{array}$ & $\begin{array}{c}1 \\
(61 \%)\end{array}$ \\
\hline 9. Rehabilitated & $\begin{array}{c}3 \\
(53 \%)\end{array}$ & $\begin{array}{c}3 \\
(51 \%)\end{array}$ & $\begin{array}{c}3 \\
(42 \%)\end{array}$ & $\begin{array}{c}2 \\
(43 \%)\end{array}$ & $\begin{array}{c}2 \\
(31 \%)\end{array}$ & $\begin{array}{c}2 \\
(44 \%)\end{array}$ \\
\hline $\begin{array}{l}\text { 15. Has Already Paid } \\
\text { Substantial Civil Compensation } \\
\text { to the Victim }\end{array}$ & $\begin{array}{c}2 \\
(65 \%)\end{array}$ & $\begin{array}{c}2 \\
(53 \%)\end{array}$ & $\begin{array}{c}2 \\
(44 \%)\end{array}$ & $\begin{array}{c}6 \\
(28 \%)\end{array}$ & $\begin{array}{c}10 \\
(14 \%)\end{array}$ & $\begin{array}{c}3 \\
(41 \%)\end{array}$ \\
\hline $\begin{array}{l}\text { 3. Truly Remorseful with Public } \\
\text { Acknowledgment of Guilt and } \\
\text { Apology }\end{array}$ & $\begin{array}{c}4 \\
(53 \%)\end{array}$ & $\begin{array}{c}5 \\
(48 \%)\end{array}$ & $\begin{array}{c}5 \\
(38 \%)\end{array}$ & $\begin{array}{c}5 \\
(28 \%)\end{array}$ & $\begin{array}{c}3 \\
(21 \%)\end{array}$ & $\begin{array}{c}4 \\
(38 \%)\end{array}$ \\
\hline $\begin{array}{l}\text { 16. Hardship for Offender's } \\
\text { Family or Others }\end{array}$ & $\begin{array}{c}5 \\
(50 \%)\end{array}$ & $\begin{array}{c}4 \\
(51 \%)\end{array}$ & $\begin{array}{c}4 \\
(41 \%)\end{array}$ & $\begin{array}{c}4 \\
(29 \%)\end{array}$ & $\begin{array}{c}16 \\
(8 \%)\end{array}$ & $\begin{array}{c}5 \\
(36 \%)\end{array}$ \\
\hline $\begin{array}{l}\text { 14. Already Suffering from His } \\
\text { Offense }\end{array}$ & $\begin{array}{c}6 \\
(46 \%)\end{array}$ & $\begin{array}{c}7 \\
(37 \%)\end{array}$ & $\begin{array}{c}7 \\
(28 \%)\end{array}$ & $\begin{array}{c}3 \\
(40 \%)\end{array}$ & $\begin{array}{c}9 \\
(14 \%)\end{array}$ & $\begin{array}{c}6 \\
(33 \%)\end{array}$ \\
\hline $\begin{array}{l}\text { 2. Public Acknowledgment of } \\
\text { Guilt plus Apology }\end{array}$ & $\begin{array}{c}8 \\
(45 \%)\end{array}$ & $\begin{array}{c}6 \\
(42 \%)\end{array}$ & $\begin{array}{c}6 \\
(30 \%)\end{array}$ & $\begin{array}{c}12 \\
(20 \%)\end{array}$ & $\begin{array}{c}8 \\
(15 \%)\end{array}$ & $\begin{array}{c}7 \\
(30 \%)\end{array}$ \\
\hline $\begin{array}{l}\text { 17. Hardship for Offender } \\
\text { Himself }\end{array}$ & $\begin{array}{c}7 \\
(45 \%)\end{array}$ & $\begin{array}{c}10 \\
(31 \%)\end{array}$ & $\begin{array}{c}8 \\
(27 \%)\end{array}$ & $\begin{array}{c}8 \\
(24 \%)\end{array}$ & $\begin{array}{c}11 \\
(13 \%)\end{array}$ & $\begin{array}{c}8 \\
(28 \%)\end{array}$ \\
\hline $\begin{array}{l}\text { 6. Victim Wants Less or No } \\
\text { Punishment }\end{array}$ & $\begin{array}{c}9 \\
(40 \%)\end{array}$ & $\begin{array}{c}9 \\
(32 \%)\end{array}$ & $\begin{array}{c}14 \\
(16 \%)\end{array}$ & $\begin{array}{c}7 \\
(25 \%)\end{array}$ & $\begin{array}{c}4 \\
(19 \%)\end{array}$ & $\begin{array}{c}9 \\
(27 \%)\end{array}$ \\
\hline $\begin{array}{l}\text { 1. Public Acknowledgment of } \\
\text { Guilt }\end{array}$ & $\begin{array}{c}11 \\
(32 \%)\end{array}$ & $\begin{array}{c}8 \\
(35 \%)\end{array}$ & $\begin{array}{c}9 \\
(26 \%)\end{array}$ & $\begin{array}{c}10 \\
(22 \%)\end{array}$ & $\begin{array}{c}5 \\
(16 \%)\end{array}$ & $\begin{array}{c}10 \\
(26 \%)\end{array}$ \\
\hline 18. Old Age & $\begin{array}{c}10 \\
(33 \%)\end{array}$ & $\begin{array}{c}12 \\
(26 \%)\end{array}$ & $\begin{array}{c}11 \\
(22 \%)\end{array}$ & $\begin{array}{c}11 \\
(21 \%)\end{array}$ & $\begin{array}{c}14 \\
(10 \%)\end{array}$ & $\begin{array}{c}11 \\
(22 \%)\end{array}$ \\
\hline $\begin{array}{l}\text { 7. Victim Wants More } \\
\text { Punishment }\end{array}$ & $\begin{array}{c}15 \\
(20 \%)\end{array}$ & $\begin{array}{c}16 \\
(19 \%)\end{array}$ & $\begin{array}{c}10 \\
(25 \%)\end{array}$ & $\begin{array}{c}9 \\
(23 \%)\end{array}$ & $\begin{array}{c}6 \\
(15 \%)\end{array}$ & $\begin{array}{c}12 \\
(20 \%)\end{array}$ \\
\hline 11. Good Deeds After Offense & $\begin{array}{c}13 \\
(26 \%)\end{array}$ & $\begin{array}{c}11 \\
(29 \%)\end{array}$ & $\begin{array}{c}15 \\
(16 \%)\end{array}$ & $\begin{array}{c}13 \\
(17 \%)\end{array}$ & $\begin{array}{c}15 \\
(10 \%)\end{array}$ & $\begin{array}{c}13 \\
(20 \%)\end{array}$ \\
\hline 5. Forgiveness by Victim & $\begin{array}{c}12 \\
(31 \%)\end{array}$ & $\begin{array}{c}13 \\
(23 \%)\end{array}$ & $\begin{array}{c}17 \\
(13 \%)\end{array}$ & $\begin{array}{c}14 \\
(16 \%)\end{array}$ & $\begin{array}{c}13 \\
(12 \%)\end{array}$ & $\begin{array}{c}14 \\
(19 \%)\end{array}$ \\
\hline 12. Bad Deeds or Character & $\begin{array}{c}17 \\
(14 \%)\end{array}$ & $\begin{array}{c}14 \\
(21 \%)\end{array}$ & $\begin{array}{c}12 \\
(20 \%)\end{array}$ & $\begin{array}{c}15 \\
(16 \%)\end{array}$ & $\begin{array}{c}7 \\
(15 \%)\end{array}$ & $\begin{array}{c}15 \\
(17 \%)\end{array}$ \\
\hline 8. Public Outrage over Offense & $\begin{array}{c}16 \\
(16 \%)\end{array}$ & $\begin{array}{c}17 \\
(17 \%)\end{array}$ & $\begin{array}{c}13 \\
(17 \%)\end{array}$ & $\begin{array}{c}16 \\
(15 \%)\end{array}$ & $\begin{array}{c}12 \\
(13 \%)\end{array}$ & $\begin{array}{c}16 \\
(16 \%)\end{array}$ \\
\hline 10. Good Deeds Before Offense & $\begin{array}{c}14 \\
(20 \%)\end{array}$ & $\begin{array}{c}15 \\
(20 \%)\end{array}$ & $\begin{array}{c}16 \\
(15 \%)\end{array}$ & $\begin{array}{c}17 \\
(12 \%)\end{array}$ & $\begin{array}{c}17 \\
(7 \%)\end{array}$ & $\begin{array}{c}17 \\
(15 \%)\end{array}$ \\
\hline 13. Special Talents & $\begin{array}{c}18 \\
(14 \%)\end{array}$ & $\begin{array}{c}18 \\
(12 \%)\end{array}$ & $\begin{array}{c}18 \\
(11 \%)\end{array}$ & $\begin{array}{c}18 \\
(10 \%)\end{array}$ & $\begin{array}{c}18 \\
(6 \%)\end{array}$ & $\begin{array}{c}18 \\
(11 \%)\end{array}$ \\
\hline
\end{tabular}

Some XPFs, however, change noticeably in their relative popularity, especially for the homicide offenses in Scenarios D and E. The second most popular XPF for theft, personal injury, and corruption-XPF 15 ("Has Already Paid Substantial Civil Compensation to the Victim")—drops to sixth for the reckless-killing 
scenario and to tenth for the murder scenario. In other words, it is not simply that XPF popularity falls as the seriousness of the offense increases, but that XPF popularity in relation to other XPFs also falls as the underlying offense becomes more serious.

For some XPFs, the drop-off in relative popularity occurs just for the murder case. For example, XPF 16 ("Hardship for Offender's Family or Others") holds steady at either fourth or fifth place for most offenses but drops dramatically to sixteenth for murder. ${ }^{243}$ Similarly, XPF 14 ("Already Suffering from His Offense") ranks between third and seventh in Scenarios A through D but drops to ninth place in Scenario E. ${ }^{244}$

In contrast, some XPFs become relatively more popular as the underlying offense becomes more serious. For example, XPF 8 ("Public Outrage over Offense") moves from sixteenth in Scenario A to twelfth in Scenario E. Another aggravator of relatively weak popularity-XPF 12 ("Bad Deeds or Character")—similarly increases its popularity relative to other XPFs, at least for the most serious offense, murder. ${ }^{245}$ This trend raises an interesting interpretive issue. It may be that XPFs like these two increase in rank not because the logic of the mitigation is more compelling as applied to serious offenses but rather because other mitigations are less persuasive and the rankings of these XPFs increase primarily because they hold their popularity while others lose theirs.

One final interesting pattern of this sort is found in the pair of XPFs relating to victim desire for more or for less punishment. The relative popularity of XPF 6 ("Victim Wants Less or No Punishment") increases its rank from mid-range for nonhomicide offenses to fourth for murder. At the same time, XPF 7 ("Victim Wants More Punishment") moves from fifteenth place in Scenario A to sixth place in Scenario E. Thus, victim views on punishment appear to be taken more into account as offense seriousness rises.

243. See id. (ranking XPF 16 as $5-4-4-4-16$ ).

244. See id. (ranking XPF 14 as $6-7-7-3-9$ ). A somewhat less dramatic example is found for XPF 17 ("Hardship for Offender Himself"). This mitigation ranks between seventh and tenth place in Scenarios A through D but dropped to eleventh place for murder. Old age as a mitigation (XPF 18) shows a similar minor drop in relative popularity for murder, ranking tenth to twelfth in Scenarios A through D, but dropping to fourteenth for murder. See id. (ranking XPF 18 as $10-12-11-11-14)$.

245. See id. (ranking XPF 12 as $17-14-12-15-7$ ). XPF 9 ("Rehabilitated") exhibits a similar pattern, moving from third in Scenario A to second in Scenario E. So too does XPF 1 ("Public Acknowledgment of Guilt"), which increases from eleventh place in Scenario A to fifth place in Scenario E. See id. (ranking XPF 1 as $11-8-9-10-5$ ). 


\section{F. Demographic Differences}

In conducting the study, we collected data on respondents' race, marital status, gender, income, age, and education level. Race, marital status, and gender were each coded as categorical variables (i.e., variables with two or more categories with no intrinsic ordering to the categories). Income, age, and education level, on the other hand, were recorded as continuous variables (i.e., the relative values are ordered and magnitudes are straightforwardly interpretable). Tables 9 through 12 below explore the ways in which these variables influence $\mathrm{XPF}$ popularity and XPF magnitude.

\section{Demographic Differences and Popularity}

Table 9 reports differences in XPF popularity by race, marital status, and gender. The number in each cell corresponds to the difference in support between demographic groups. Positive values indicate that white, unmarried, or male subjects changed punishment more often than did nonwhite, married, or female subjects; negative values indicate that nonwhite, married, or female subjects changed punishment more often. For instance, the value $-23.6 \%$, as reported for XPF 15 in Scenario A, indicates that XPF popularity among nonwhite respondents exceeded XPF popularity among white respondents by $23.6 \%$. Table 9 contains only statistically significant values and designates those XPFs that were expected to aggravate, rather than mitigate, punishment. 
TABLE 9. STATISTICALly SignificANT DifFERENCES IN XPF PopUlarity By RACE, MARITAL STATUS, AND GENDER

\begin{tabular}{|c|c|c|c|c|c|c|}
\hline \multirow[b]{2}{*}{ XPFs } & \multicolumn{6}{|c|}{ Scenarios } \\
\hline & $\begin{array}{c}\text { A. } \\
\text { Theft with } \\
\text { Trespass }\end{array}$ & $\begin{array}{c}\text { B. } \\
\text { Personal } \\
\text { Injury }\end{array}$ & $\begin{array}{c}\text { C. } \\
\text { Governmental } \\
\text { Corruption }\end{array}$ & $\begin{array}{c}\text { D. } \\
\text { Causing } \\
\text { Death by } \\
\text { Risk Taking }\end{array}$ & $\begin{array}{c}\text { E. } \\
\text { Intentional } \\
\text { Killing and } \\
\text { Abduction }\end{array}$ & $\begin{array}{c}\text { Row } \\
\text { Averages }\end{array}$ \\
\hline $\begin{array}{l}\text { 4. True Remorse, } \\
\text { Acknowledgment of Guilt, } \\
\text { and Apology Immediately } \\
\text { After Offense }\end{array}$ & & & & & & \\
\hline 9. Rehabilitated & & & & & gen $-16.4 \%$ & \\
\hline $\begin{array}{l}\text { 15. Has Already Paid } \\
\text { Substantial Civil } \\
\text { Compensation to the } \\
\text { Victim }\end{array}$ & race $-23.6 \%$ & & & & race $16.1 \%$ & \\
\hline $\begin{array}{l}\text { 3. Truly Remorseful with } \\
\text { Public Acknowledgment of } \\
\text { Guilt and Apology }\end{array}$ & & & & & & gen $7.1 \%$ \\
\hline $\begin{array}{l}\text { 16. Hardship for } \\
\text { Offender's Family or } \\
\text { Others }\end{array}$ & & & race $21.6 \%$ & & & race $10.3 \%$ \\
\hline $\begin{array}{l}\text { 14. Already Suffering from } \\
\text { His Offense }\end{array}$ & $\operatorname{mar} 17.0 \%$ & & & & & race $10.0 \%$ \\
\hline $\begin{array}{l}\text { 2. Public Acknowledgment } \\
\text { of Guilt plus Apology }\end{array}$ & gen $14.4 \%$ & gen $16.6 \%$ & & gen $17.9 \%$ & & gen $9.4 \%$ \\
\hline $\begin{array}{l}\text { 17. Hardship for Offender } \\
\text { Himself }\end{array}$ & race $16.0 \%$ & & & & race $14.8 \%$ & race $12.2 \%$ \\
\hline $\begin{array}{l}\text { 6. Victim Wants Less or } \\
\text { No Punishment }\end{array}$ & & & & race $13.6 \%$ & race $13.1 \%$ & $\begin{array}{l}\text { race } 9.8 \% \\
\text { gen } 8.0 \%\end{array}$ \\
\hline $\begin{array}{l}\text { 1. Public Acknowledgment } \\
\text { of Guilt }\end{array}$ & gen $20.2 \%$ & & & $\begin{array}{l}\text { race } 13.2 \% \\
\text { gen } 13.2 \%\end{array}$ & & $\begin{array}{l}\text { race } 5.7 \% \\
\text { gen } 9.7 \%\end{array}$ \\
\hline 18. Old Age & & & & gen $14.9 \%$ & race $13.7 \%$ & race $9.1 \%$ \\
\hline $\begin{array}{l}\text { 7. Victim Wants More } \\
\text { Punishment } \\
\text { - aggravation XPF }\end{array}$ & $\operatorname{mar} 11.3 \%$ & race $18.4 \%$ & & race $23.7 \%$ & race $15.6 \%$ & race $11.9 \%$ \\
\hline $\begin{array}{l}\text { 11. Good Deeds After } \\
\text { Offense }\end{array}$ & race $13.8 \%$ & race $16.4 \%$ & & $\operatorname{mar} 13.8 \%$ & $\begin{array}{l}\text { race } 11.2 \% \\
\text { gen }-9.3 \%\end{array}$ & $\begin{array}{l}\text { race } 8.1 \% \\
\operatorname{mar} 8.3 \%\end{array}$ \\
\hline 5. Forgiveness by Victim & race $15.9 \%$ & race $13.3 \%$ & & & race $20.8 \%$ & race $13.9 \%$ \\
\hline $\begin{array}{l}\text { 12. Bad Deeds or } \\
\text { Character } \\
\text { - aggravation XPF }\end{array}$ & race $15.6 \%$ & race $13.3 \%$ & $\operatorname{mar}-16.3 \%$ & race $19.5 \%$ & race $16.5 \%$ & $\begin{array}{c}\text { race } 12.5 \% \\
\text { gen } 6.1 \%\end{array}$ \\
\hline $\begin{array}{l}\text { 8. Public Outrage over } \\
\text { Offense } \\
\text { - aggravation XPF }\end{array}$ & $\begin{array}{l}\text { race } 12.3 \% \\
\text { mar } 15.7 \%\end{array}$ & race $15.7 \%$ & & & race $12.2 \%$ & $\begin{array}{l}\text { race } 11.2 \% \\
\operatorname{mar} 7.3 \%\end{array}$ \\
\hline $\begin{array}{l}\text { 10. Good Deeds Before } \\
\text { Offense }\end{array}$ & & $\begin{array}{c}\text { race } 16.7 \% \\
\text { gen } 13.2\end{array}$ & & & & $\begin{array}{l}\text { race } 5.5 \% \\
\text { gen } 5.7 \%\end{array}$ \\
\hline 13. Special Talents & & & & race $10.1 \%$ & race $14.6 \%$ & race $7.1 \%$ \\
\hline Column Averages & gen $5.7 \%$ & $\begin{array}{l}\text { race } 5.5 \% \\
\text { mar } 5.2 \% \\
\text { gen } 4.4 \%\end{array}$ & $\operatorname{mar}-3.7 \%$ & $\begin{array}{l}\text { race } 9.3 \% \\
\operatorname{mar} 3.6 \% \\
\text { gen } 5.6 \%\end{array}$ & race $9.4 \%$ & $\begin{array}{c}\text { race } 5.7 \% \\
\text { mar } 1.7 \% \\
\text { gen } 3.4 \%\end{array}$ \\
\hline
\end{tabular}

NB: A positive value indicates that white, unmarried, or male subjects changed punishment more than nonwhite, married, or female subjects did by that percentage amount. Only differences significant at the $\mathrm{p}<0.05$ level are reported. 
Race. Race seems to have the greatest demographic effect on the popularity of XPFs. In the fifteen mitigation XPFs, ${ }^{246} \mathrm{XPF}$ popularity among whites was significantly greater than among nonwhites in seventeen of the seventy-five variations. XPF popularity was significantly greater among nonwhites in only one variation. But whites were not generally more sympathetic to all offenders. In the three aggravation XPFs, XPF popularity among white subjects was significantly different from XPF popularity among nonwhites in ten of the fifteen variations, while in none of these variations was XPF popularity greater among nonwhites. Column averages show that, generalizing across all XPFs, whites adjusted punishment significantly more than nonwhites in three scenarios. Row averages show that, generalizing across all scenarios, they adjusted punishment significantly more than nonwhites for thirteen of the eighteen XPFs. The "all cells" figure shows that overall XPF popularity among whites exceeded XPF popularity among nonwhites by a statistically significant $5.7 \%$.

Gender. Gender has less of an effect on XPF popularity than race. XPF popularity among males was often greater than among females. In the fifteen mitigation XPFs, males adjusted punishment significantly more often than did females in seven of seventy-five variations. Females adjusted punishment significantly more than males in only two variations. In none of the three aggravation XPF variations did gender produce a statistically significant difference between genders, though XPF 12 ("Bad Deeds or Character") did show an overall significant difference. Column averages show that, generalizing across all XPFs, males were more likely to make a punishment adjustment than females in three of the five scenarios. Row averages show that, generalizing across all scenarios, XPF popularity among males was significantly greater than among females for six of the eighteen XPFs. The "all cells" figure shows that overall XPF popularity among males exceeded XPF popularity among females by a statistically significant $3.4 \%$.

Marital Status. Marital status seems to have the least effect of the demographic factors. In the fifteen mitigation XPFs, XPF popularity among unmarried respondents was significantly greater than among married respondents in two of the seventy-five variations. In the three aggravation XPFs, XPF popularity among unmarried respondents was greater than among married respondents in two of the fifteen variations; in one instance XPF popularity among married respondents was greater. Column averages show that, generalizing

246. Three of the XPFs invited aggravations of punishment, as noted in supra Table 11. 
across all XPFs, unmarried subjects adjusted punishment significantly more often than did married respondents in only two of the five scenarios. Row averages show that, generalizing across scenarios, XPF popularity among unmarried respondents was significantly greater than among married respondents for two of the eighteen XPFs. The "all cells" figure indicates that overall XPF popularity among unmarried respondents exceeded XPF popularity among married respondents by a slight though statistically significant $1.7 \%$.

In overview, according to the "all cells" figure, XPF popularity among white, male, or unmarried respondents was greater than among nonwhite, female, or married respondents, though the actual difference was slight: only $5.7 \%, 3.4 \%$, and $1.7 \%$, respectively. This pattern held true in Scenarios B and D, where across all XPFs white, male, or unmarried subjects tended to record more adjustments than did their nonwhite, female, or married counterparts, but again with single-digit differences. For XPFs across scenarios, all but the three most popular XPFs showed significant differences in XPF popularity among at least one demographic group, but again the extent of the differences rarely reached above single digits.

Next, Table 10 reports the effect of age, income, and education on XPF popularity. The values in each cell represent the correlation between XPF popularity on the one hand and income, age, or education on the other. A positive correlation indicates that as income, age, or education level increases, the likelihood that a respondent would chose to change punishment increases. A negative correlation indicates that as income, age, or education level increases, the likelihood that a respondent would chose to change punishment decreases. Only statistically significant correlations are reported.

Income. Income seems to have a weak effect on XPF popularity. Income significantly correlates with XPF popularity in only two XPF variations: XPF 4 under Scenario D and XPF 11 under Scenario D. Generalizing across scenarios, income only has a significant effect on XPF 4, suggesting that at least for XPF 4 ("True Remorse, Acknowledgment of Guilt, and Apology Immediately After Offense"), as income increases so too does the XPF's intuitive appeal. XPF 4 seems to be an isolated example, however. Generalizing across XPFs, income has no significant effect on XPF popularity. Similarly, generally across all responses, there was no significant correlation between income and XPF popularity. 


\section{TABLE 10. STATISTICALLY SIGNIFICANT DIFFERENCES IN XPF POPULARITY BY INCOME, AGE, AND EDUCATION}

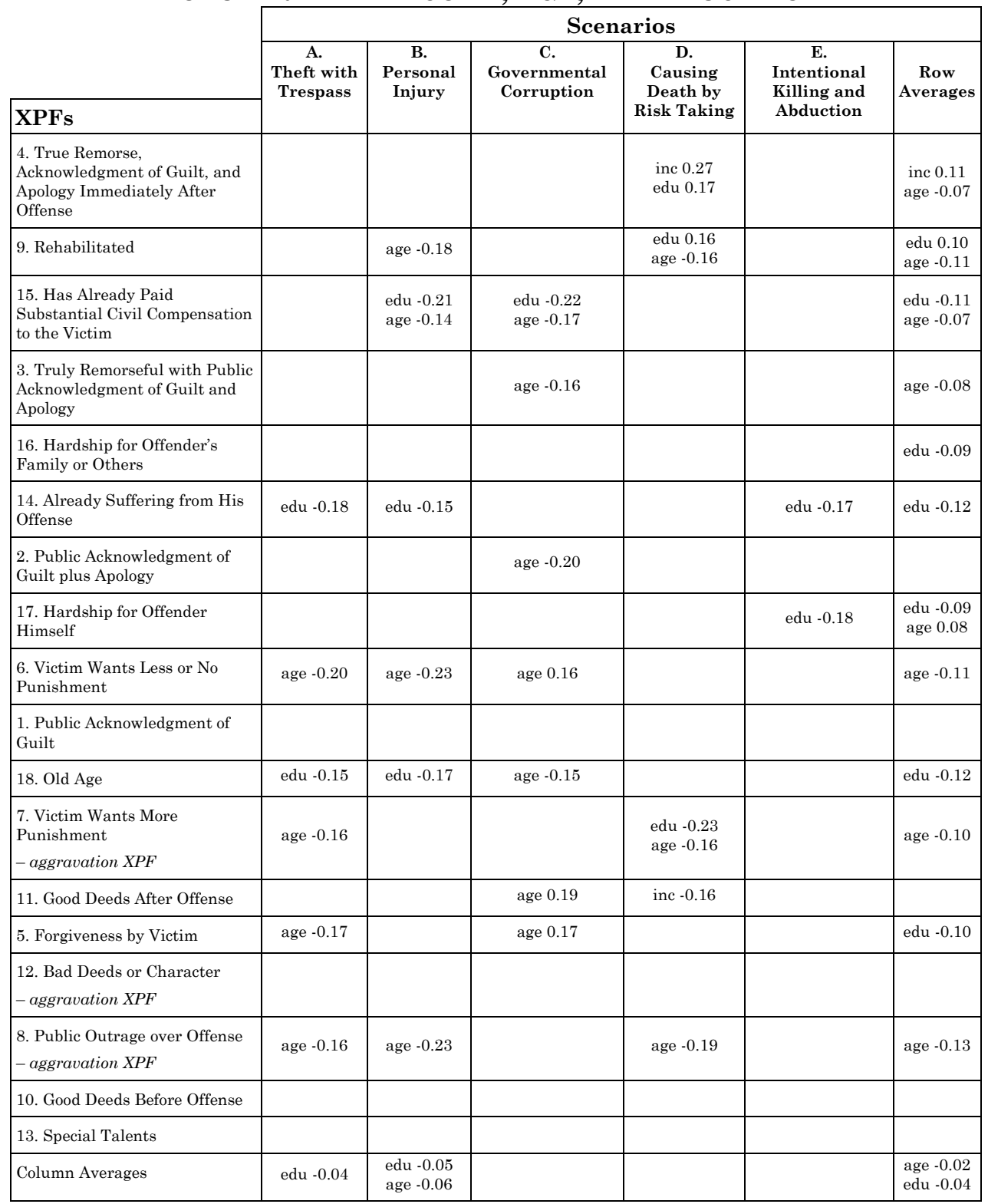

NB: Values are correlations. A positive value means that as age, income, or education increases, XPF popularity increases, and a negative value means that as age, income, or education increases, XPF popularity decreases. Only values significant at the $p<0.05$ level are reported. 
Age. In some variations, age seems to play a significant role in determining whether to apply an XPF. Significance was found in eighteen of the variations tested, though the size of the correlation was minimal in all variations. Notably, where the correlation with age was statistically significant, as age increased, the likelihood that a respondent would change his punishment decreased. Indeed, generalizing across scenarios, this sort of relationship was found in XPFs $3,4,7,8,9$, and 15, and generally across all responses there was a slight negative correlation between XPF popularity and age (-0.02).

Education. Education also seemed to play a significant role in some variations. Significance was found in eleven of the variations tested. Generalizing across XPFs, there was a slight though significant correlation found between education and XPF popularity in responses to Scenarios A ("Theft with Trespass") and B ("Personal Injury"). Generalizing across scenarios, seven XPFs showed some correlation with education, all but one of them negative. ${ }^{247}$ That statistical significance was found generally for XPFs 14 through 18, which constitute Group D ("Suffering Apart from Official Punishment"). This suggests that as education level increases Group D's rationale is less persuasive. Still, the correlation is slight. Across all responses, a slight negative correlation was found to be statistically significant.

\section{Demographic Differences and Magnitude}

In addition, we analyzed the relationship between the demographic variable and XPF magnitude. Our findings are shown in Tables 11 and 12 below.

Table 11 reports the relationship between race, marital status, and gender on the one hand and XPF magnitude on the other. To calculate the value in each cell, we took the absolute value of the average response among each demographic group (measured in ESN values) and subtracted the average among white, married, or male responses from the average among nonwhite, unmarried, or female responses. Accordingly, a positive value indicates that the average ESN value among white, married, or male responses was greater and a negative value indicates that it was smaller. Usually, the values here connote a decrease in punishment but, for the XPFs marked as "aggravation XPF," the values actually connote an increase in punishment.

247. XPFs 5, 14, 15 16, 17, and 18 demonstrated a negative correlation with education. XPF 4 demonstrated a positive correlation. 


\section{TABLE 11. STATISTICALly SignifiCANT DifFERENCES IN XPF MAGNITUDE BY RACE, MARITAL STATUS, AND GENDER}

\begin{tabular}{|c|c|c|c|c|c|c|}
\hline \multirow{2}{*}{ XPFs } & \multicolumn{6}{|c|}{ Scenarios } \\
\hline & $\begin{array}{c}\text { A. } \\
\text { Theft with } \\
\text { Trespass }\end{array}$ & $\begin{array}{c}\text { B. } \\
\text { Personal } \\
\text { Injury }\end{array}$ & $\begin{array}{c}\text { C. } \\
\text { Governmental } \\
\text { Corruption }\end{array}$ & $\begin{array}{c}\text { D. } \\
\text { Causing } \\
\text { Death by } \\
\text { Risk Taking }\end{array}$ & $\begin{array}{c}\text { E. } \\
\text { Intentional } \\
\text { Killing and } \\
\text { Abduction }\end{array}$ & $\begin{array}{l}\text { Row } \\
\text { Averages }\end{array}$ \\
\hline $\begin{array}{l}\text { 4. True Remorse, } \\
\text { Acknowledgment of Guilt, and } \\
\text { Apology Immediately After } \\
\text { Offense }\end{array}$ & & race 0.332 & $\begin{array}{l}\text { race } 0.484 \\
\text { mar }-0.410\end{array}$ & & & \\
\hline 9. Rehabilitated & & & & & & mar 0.105 \\
\hline $\begin{array}{l}\text { 15. Has Already Paid } \\
\text { Substantial Civil Compensation } \\
\text { to the Victim }\end{array}$ & & & & & & \\
\hline $\begin{array}{l}\text { 3. Truly Remorseful with Public } \\
\text { Acknowledgment of Guilt and } \\
\text { Apology }\end{array}$ & & & & & race 0.173 & race 0.116 \\
\hline $\begin{array}{l}\text { 16. Hardship for Offender's } \\
\text { Family or Others }\end{array}$ & & & & & & \\
\hline $\begin{array}{l}\text { 14. Already Suffering from His } \\
\text { Offense }\end{array}$ & & race 0.280 & & & & \\
\hline $\begin{array}{l}\text { 2. Public Acknowledgment of } \\
\text { Guilt plus Apology }\end{array}$ & & & & & & \\
\hline $\begin{array}{l}\text { 17. Hardship for Offender } \\
\text { Himself }\end{array}$ & race 0.503 & & & & & \\
\hline $\begin{array}{l}\text { 6. Victim Wants Less or No } \\
\text { Punishment }\end{array}$ & & & & & & \\
\hline $\begin{array}{l}\text { 1. Public Acknowledgment of } \\
\text { Guilt }\end{array}$ & & & & & race 0.010 & gen 0.090 \\
\hline 18. Old Age & & & & gen 0.376 & & \\
\hline $\begin{array}{l}\text { 7. Victim Wants More } \\
\text { Punishment } \\
\text { - aggravation XPF }\end{array}$ & & race 0.147 & & & & race 0.123 \\
\hline 11. Good Deeds After Offense & race 0.230 & & race 0.260 & & & \\
\hline 5. Forgiveness by Victim & & & & & & \\
\hline $\begin{array}{l}\text { 12. Bad Deeds or Character } \\
\text { - aggravation XPF }\end{array}$ & & & & & race 0.152 & \\
\hline $\begin{array}{l}\text { 8. Public Outrage over Offense } \\
\text { - aggravation XPF }\end{array}$ & & & & & & \\
\hline 10. Good Deeds Before Offense & & & race 0.235 & & & \\
\hline 13. Special Talents & & & & & & \\
\hline Column Averages & & race 0.119 & race 0.115 & & & race 0.053 \\
\hline
\end{tabular}

NB: Values are absolute differences in average ESNs, including responses of 0 (no change). A positive value indicates that the average white, married, or male response was greater than the average nonwhite, unmarried, or female response by that amount. A negative value indicates that the average nonwhite, unmarried, or female response was greater than the average white, married, or male response by that amount. Only values significant at the $p<0.05$ level are reported. 
Race. Race was a relatively important predictor of XPF magnitude, though it was only found to be a statistically significant predictor variable in eleven variations. For eight variations, the average punishment change among white respondents exceeded that of nonwhite respondents. For the remaining three, the inverse was true: the average punishment change among nonwhite respondents exceeded that of white respondents. Generalizing across XPFs, a significant relationship was found for only two XPFs: XPF 3 and 7. For XPF 3 ("Truly Remorseful with Public Acknowledgment of Guilt and Apology"), the average among white respondents exceeded the average among nonwhite respondents by an ESN value of 0.116 . For XPF 7 ("Victim Wants More Punishment"), which is an aggravation XPF, the average among nonwhite respondents exceeded the average among white respondents by an ESN value of 0.123 , indicating that nonwhite respondents gave more punishment than did white respondents when the victim wanted more punishment. Generalizing across XPFs, a significant relationship was found in Scenarios B ("Personal Injury") and C ("Governmental Corruption"), with the average among whites exceeding the average among nonwhites in both situations. Across all responses, white responses exceeded nonwhite responses by an average ESN value of 0.053 .

Gender. The difference between male and female average responses was statistically significant in only one XPF: XPF 18 ("Old Age") in Scenario D ("Causing Death by Risk Taking"). A slight, though still significant, difference was found across all scenarios in XPF 1 ("Public Acknowledgment of Guilt"). No other significant differences were found, suggesting that male and female respondents did not significantly disagree about much when it came to assigning punishment in light of one of the punishment factors tested.

Marital Status. Likewise, there was only one statistically significant difference between married and unmarried responses: XPF 4 ("True Remorse, Acknowledgment of Guilt, and Apology Immediately After Offense") in Scenario C ("Governmental Corruption"). Generalizing across scenarios, a significant difference was also found for XPF 9 ("Rehabilitated"). For XPF 9, the married average exceeded the nonmarried average by 0.105 , indicating a greater punishment deduction among married respondents. No other statistically significant difference was found. 


\section{TABLE 12. STATISTICALLY SIGNIFICANT CORRELATIONS WITH XPF MAGNITUDE FOR AGE, INCOME, AND EDUCATION}

\begin{tabular}{|c|c|c|c|c|c|c|}
\hline \multirow[b]{2}{*}{ XPFs } & \multicolumn{6}{|c|}{ Scenarios } \\
\hline & $\begin{array}{c}\text { A. } \\
\text { Theft with } \\
\text { Trespass }\end{array}$ & $\begin{array}{c}\text { B. } \\
\text { Personal } \\
\text { Injury }\end{array}$ & $\begin{array}{c}\text { C. } \\
\text { Governmental } \\
\text { Corruption }\end{array}$ & $\begin{array}{c}\text { D. } \\
\text { Causing } \\
\text { Death by } \\
\text { Risk Taking }\end{array}$ & $\begin{array}{l}\text { E. } \\
\text { Intentional } \\
\text { Killing and } \\
\text { Abduction }\end{array}$ & $\begin{array}{c}\text { Row } \\
\text { Averages }\end{array}$ \\
\hline $\begin{array}{l}\text { 4. True Remorse, } \\
\text { Acknowledgment of Guilt, and } \\
\text { Apology Immediately After } \\
\text { Offense }\end{array}$ & & inc -0.26 & & inc -0.25 & $\begin{array}{l}\text { edu }-0.14 \\
\text { inc }-0.24\end{array}$ & inc -0.12 \\
\hline 9. Rehabilitated & age -0.17 & & & edu -0.23 & & edu -0.09 \\
\hline $\begin{array}{l}\text { 15. Has Already Paid } \\
\text { Substantial Civil Compensation } \\
\text { to the Victim }\end{array}$ & & & $\begin{array}{l}\text { age } 0.17 \\
\text { edu } 0.18\end{array}$ & & & \\
\hline $\begin{array}{l}\text { 3. Truly Remorseful with Public } \\
\text { Acknowledgment of Guilt and } \\
\text { Apology }\end{array}$ & inc -0.15 & $\begin{array}{l}\text { edu } 0.01 \\
\text { inc } 0.20\end{array}$ & & inc 0.16 & $\begin{array}{l}\text { edu }-0.13 \\
\text { inc } 0.15\end{array}$ & \\
\hline $\begin{array}{l}\text { 16. Hardship for Offender's } \\
\text { Family or Others }\end{array}$ & & & & & & edu 0.07 \\
\hline $\begin{array}{l}\text { 14. Already Suffering from His } \\
\text { Offense }\end{array}$ & & inc -0.16 & & & & age -0.08 \\
\hline $\begin{array}{l}\text { 2. Public Acknowledgment of } \\
\text { Guilt plus Apology }\end{array}$ & & & & & $\begin{array}{l}\text { edu }-0.14 \\
\text { inc }-0.18\end{array}$ & inc -0.08 \\
\hline $\begin{array}{l}\text { 17. Hardship for Offender } \\
\text { Himself }\end{array}$ & & $\begin{array}{l}\text { age }-0.17 \\
\text { inc }-0.18\end{array}$ & & & & age -0.10 \\
\hline $\begin{array}{l}\text { 6. Victim Wants Less or No } \\
\text { Punishment }\end{array}$ & & & age 0.15 & & & \\
\hline $\begin{array}{l}\text { 1. Public Acknowledgment of } \\
\text { Guilt }\end{array}$ & & & & & $\begin{array}{l}\text { edu }-0.18 \\
\text { inc } 0.19\end{array}$ & \\
\hline 18. Old Age & & & & & $\begin{array}{l}\text { age }-0.22 \\
\text { inc }-0.20\end{array}$ & age -0.09 \\
\hline \multicolumn{7}{|l|}{$\begin{array}{l}\text { 7. Victim Wants More } \\
\text { Punishment } \\
\text { - aggravation XPF }\end{array}$} \\
\hline 11. Good Deeds After Offense & & & age -0.26 & & & age -0.07 \\
\hline 5. Forgiveness by Victim & & & age -0.18 & & & \\
\hline $\begin{array}{l}\text { 12. Bad Deeds or Character } \\
\text { - aggravation XPF }\end{array}$ & & & inc -0.17 & & & \\
\hline $\begin{array}{l}\text { 8. Public Outrage over Offense } \\
\text { - aggravation XPF }\end{array}$ & & & & $\begin{array}{l}\text { age }-0.17 \\
\text { inc } 0.16\end{array}$ & & \\
\hline 10. Good Deeds Before Offense & & edu -0.15 & & edu -0.15 & & $\begin{array}{l}\text { age }-0.09 \\
\text { edu }-0.10\end{array}$ \\
\hline \multicolumn{7}{|l|}{ 13. Special Talents } \\
\hline Column Averages & age -0.08 & $\begin{array}{l}\text { age }-0.09 \\
\text { inc }-0.04\end{array}$ & age -0.06 & age -0.06 & age -0.06 & $\begin{array}{l}\text { age- } 0.06 \\
\text { inc }-0.04\end{array}$ \\
\hline
\end{tabular}

NB: Values are correlations. A positive value means a higher age, education level, or income level correlates with increasing the sentence imposed, and a negative value means those variables correlate with lower sentences. Only values significant at the $p<0.05$ level are reported. 
Age. Respondent age seems to have an effect, albeit limited, on how much respondents adjust punishment. Age significantly correlated with punishment adjustment in only eight of the ninety offense-XPF variations. In seven of those instances, higher age correlated with reducing punishment; in only one did higher age correlate with increasing punishment. Row averages show that, generalizing across all scenarios, higher age correlated with reducing punishment for five of the eighteen XPFs. The column averages all show that in each scenario as age increased there was a slight, though statistically significant, tendency for punishment adjustments to be more lenient, regardless of the XPF in question. ${ }^{248}$

Income. Respondent income seems to have somewhat less influence over the extent to which a subject adjusted punishment. Income significantly correlated with punishment adjustment in only fourteen of the ninety offense-XPF variations. In nine of those instances, higher income correlated with mitigating punishment in light of some XPF; in the other five, higher income correlated with increasing punishment. Row averages show that higher income generally correlated with reducing punishment for only two of the eighteen XPFs. ${ }^{249}$ Column averages show that when generalizing across XPFs only in Scenario B ("Personal Injury") was there a statistically significant, though slight, tendency for higher wage earners to be more sympathetic to the offender. The "all cells" figure suggests that this tendency may also be true across both XPFs and scenarios generally, though no significant correlation between income and punishment adjustment was found in Scenarios A, C, D, or E.

Education. Finally, education also has a limited effect on punishment adjustment. Education significantly correlated with punishment adjustment in only nine of the ninety offense-XPF variations. In seven of those instances, higher levels of education correlated with reducing punishment for the XPF at issue; in the other two, higher education correlated with increasing punishment. Row averages show that, generalizing across all scenarios, greater education levels correlated with punishment reductions in three of the eighteen XPFs. Column averages show that, generalizing across all $\mathrm{XPFs}$, greater education was not statistically significant in reducing punishment. ${ }^{250}$

248. The "all cells" figure reports the same finding.

249. See supra Table 12 (noting the effect of income on XPF 2 ("Public Acknowledgment of Guilt plus Apology") and XPF 4 ("True Remorse, Acknowledgment of Guilt, and Apology Immediately after Offense")).

250. Similarly, there was no significant correlation generally across all XPFs and all scenarios. 
In overview, age, income, or education correlated with punishment adjustment in only a few specific instances. Age and income have some statistically significant correlation with the amount by which respondents adjusted punishment, but the magnitude of the correlation is only slight.

To summarize, in the vast majority of XPF and base scenario variations, there are no demographic differences. However, some variations did show some differences. Being white, male, unmarried, older, richer, or more educated generally predicted a greater willingness to give the XPF mitigations tested here, though there are exceptions. We do not know, on these analyses, if there is an interactive effect among these demographic variables.

\section{G. Local vs. National Differences}

Because we collected data from both a local (Chicago, Illinois) and national (Mechanical Turk) sample, we are able to see whether, at least in this instance, the results from a particular local community vary significantly from those of a national sample. Table 13 reports the same information as Table 5 but with the local and national samples segregated, showing XPF popularity on the upper line of each cell and XPF magnitude on the lower line of each cell. For the sake of simplicity, values are reported only when the two samples had responses that were statistically significant $(p<0.05)$. When there was significance, we followed up with a regression analysis to determine whether it remained after controlling for age, income, education, race, gender, and marital status. Values are italicized if they remained significant after controlling for these demographic variables.

Table 13 indicates that there are fewer statistically significant differences between the two samples than one might expect, and even where there are statistically significant differences, they are of a small magnitude. Overall, the local sample was more likely to adjust punishment than the national sample, but only by $5.6 \% .{ }^{251}$ There was no statistically significant difference overall in XPF magnitude between the two groups.

251. See $31.9 \%$ to $26.3 \%$ in the "all cells" figures at the bottom right of the table. 
TABLE 13. COMPARISON OF LOCAL TO NATIONAL SAMPLE FOR AdJustment OF PUNishment (SCENARIOS A THROUGH C)

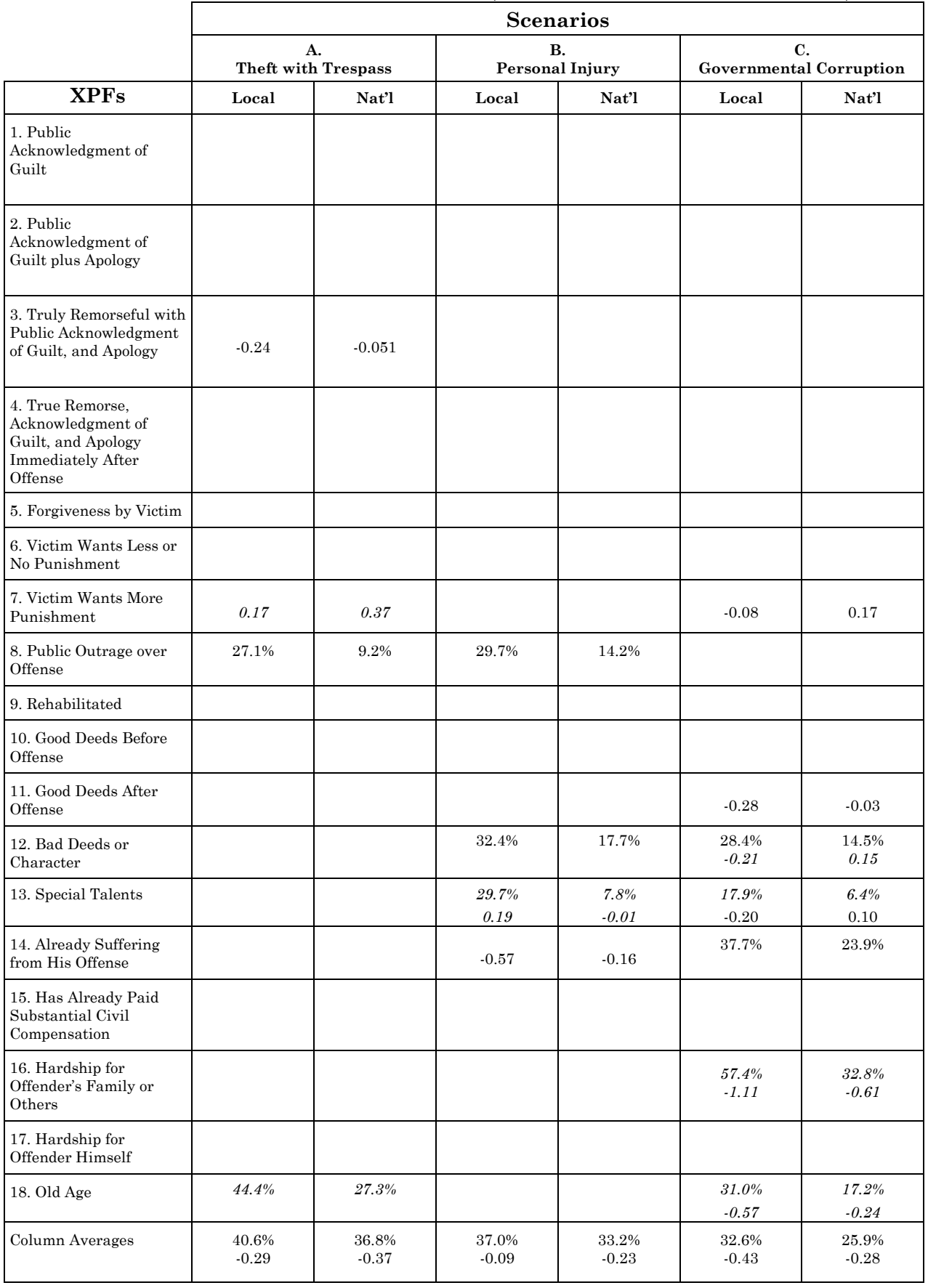


TABLE 13. COMPARISON OF LOCAL TO NATIONAL SAMPLE FOR

AdJUSTMENT OF PUNishment (SCENARIOS D THROUGH E)

\begin{tabular}{|c|c|c|c|c|c|c|}
\hline \multirow[b]{3}{*}{ XPFs } & \multicolumn{6}{|c|}{ Scenarios } \\
\hline & \multicolumn{2}{|c|}{$\begin{array}{c}\text { D. } \\
\begin{array}{c}\text { Causing Death by Risk } \\
\text { Taking }\end{array} \\
\end{array}$} & \multicolumn{2}{|c|}{$\begin{array}{c}\text { E. } \\
\begin{array}{c}\text { Intentional Killing and } \\
\text { Abduction }\end{array} \\
\end{array}$} & \multicolumn{2}{|c|}{$\begin{array}{c}\text { Row } \\
\text { Averages }\end{array}$} \\
\hline & Local & Nat'l & Local & Nat'l & Local & Nat'l \\
\hline $\begin{array}{l}\text { 1. Public Acknowledgment of } \\
\text { Guilt }\end{array}$ & & & 0.09 & -0.10 & & \\
\hline $\begin{array}{l}\text { 2. Public Acknowledgment of } \\
\text { Guilt plus Apology }\end{array}$ & & & & & $34.4 \%$ & $28.1 \%$ \\
\hline $\begin{array}{l}\text { 3. Truly Remorseful with } \\
\text { Public Acknowledgment of } \\
\text { Guilt, and Apology }\end{array}$ & & & 0.02 & -0.15 & & \\
\hline $\begin{array}{l}\text { 4. True Remorse, } \\
\text { Acknowledgement of Guilt, } \\
\text { and Apology Immediately } \\
\text { After Offense }\end{array}$ & & & & & & \\
\hline 5. Forgiveness by Victim & & & -0.20 & -0.05 & & \\
\hline $\begin{array}{l}\text { 6. Victim Wants Less or No } \\
\text { Punishment }\end{array}$ & & & & & & \\
\hline $\begin{array}{l}\text { 7. Victim Wants More } \\
\text { Punishment }\end{array}$ & & & & & $26.0 \%$ & $17.5 \%$ \\
\hline $\begin{array}{l}\text { 8. Public Outrage over } \\
\text { Offense }\end{array}$ & & & & & $20.7 \%$ & $12.9 \%$ \\
\hline 9. Rehabilitated & & & & & & \\
\hline $\begin{array}{l}\text { 10. Good Deeds Before } \\
\text { Offense }\end{array}$ & & & & & & \\
\hline 11. Good Deeds After Offense & & & & & $\begin{array}{c}24.3 \% \\
-0.18\end{array}$ & $\begin{array}{c}17.2 \% \\
-0.08\end{array}$ \\
\hline 12. Bad Deeds or Character & & & & & $\begin{array}{l}23.9 \% \\
-0.01\end{array}$ & $\begin{array}{c}13.4 \% \\
0.09\end{array}$ \\
\hline 13. Special Talents & & & $10.8 \%$ & $2.7 \%$ & $17.7 \%$ & $6.9 \%$ \\
\hline $\begin{array}{l}\text { 14. Already Suffering from } \\
\text { His Offense }\end{array}$ & & & & & $39.1 \%$ & $30.0 \%$ \\
\hline $\begin{array}{l}\text { 15. Has Already Paid } \\
\text { Substantial Civil } \\
\text { Compensation }\end{array}$ & & & $26.2 \%$ & $8.4 \%$ & & \\
\hline $\begin{array}{l}\text { 16. Hardship for Offender's } \\
\text { Family or Others }\end{array}$ & $\begin{array}{l}43.5 \% \\
-0.87\end{array}$ & $\begin{array}{l}22.2 \% \\
-0.38\end{array}$ & $19.7 \%$ & $3.1 \%$ & $\begin{array}{l}46.1 \% \\
-0.69\end{array}$ & $\begin{array}{l}30.4 \% \\
-0.46\end{array}$ \\
\hline $\begin{array}{l}\text { 17. Hardship for Offender } \\
\text { Himself }\end{array}$ & $33.9 \%$ & $19.3 \%$ & $21.3 \%$ & $9.2 \%$ & $33.5 \%$ & $25.0 \%$ \\
\hline 18. Old Age & $32.3 \%$ & $15.6 \%$ & $16.4 \%$ & $6.9 \%$ & $\begin{array}{l}29.7 \% \\
-0.40\end{array}$ & $\begin{array}{l}18.2 \% \\
-0.26\end{array}$ \\
\hline Column Averages & $29.3 \%$ & $22.1 \%$ & $19.4 \%$ & $13.5 \%$ & $31.9 \%$ & $26.3 \%$ \\
\hline
\end{tabular}

NB: Reported differences are significant at the $\mathrm{p}<0.05$ level. Those values that are significant at the $\mathrm{p}<0.05$ level after controlling for age, income, education, race, gender, and marital status are italicized. 
Row averages confirm this general tendency. Looking generally across scenarios, for seven XPFs there were significant differences in XPF popularity not attributable to demographic differences; for only two XPFs was there a significant difference in XPF magnitude not attributable to demographic differences. In contrast, column averages show that, generally across XPFs, there were no unexplainable differences between samples.

On the other hand, Table 13 also makes clear that there were some real differences in the responses of the two samples. There were eight variations that display significant differences in XPF popularity between the samples and six variations that display significant differences in XPF magnitude. Thus, the Table suggests that in some cases there may be real disagreements about whether certain XPFs merit any punishment reduction at all and if so how much. While some of these differences may be attributable to differences in testing conditions, they may also be the result of differences between the local and national community. The Chicago native might have different views than a demographically similar person who lives elsewhere.

For example, there were unexplainable differences in XPF popularity for three XPFs under Scenario C ("Governmental Corruption"): XPF 13 ("Special Talents"), XPF 16 ("Hardship for Offender's Family or Others"), and XPF 18 ("Old Age"). No other scenario had as many unexplainable significant differences in XPF popularity. The differences were quite large as well: while only $6.4 \%$ of the national respondents believed that "special talents" affected their punishment assignment for a corrupt government official, 17.9\% of the Chicago respondents thought that it did. Similarly, while family hardship influenced only $32.8 \%$ of the national respondents, it influenced a majority (57.4\%) of the Chicago respondents. Given Chicago's famed experienced with public corruption, ${ }^{252}$ this difference may be the result of a unique local political culture.

\section{H. Summary of Study Conclusions}

There is support among lay people for punishment factors that have traditionally been excluded from the criminal law's liability and punishment rules. Every XPF tested had some support, even in relation to Scenario E ("Intentional Killing and Abduction"), the most serious offense. A number of XPFs enjoyed the support of a majority of study participants, with support reaching as high as $77 \%$ for the most

252. See generally JAMES L. MERRINER, Grafters AND Goo GoOs: CORRUPtION AND REFORM IN CHICAGO (2008). 
popular XPF.253 On the other hand, most XPFs did not gain the support of a majority of study participants. Even for a relatively minor offense like that in Scenario A ("Theft with Trespass"), factors that are quite common in practice, and that policymakers, lawyers, and scholars have advocated for, failed to persuade many study participants.

Nevertheless, lay intuitions about XPFs are actually quite nuanced and sophisticated. The seriousness of the underlying offense almost always influenced decisions about whether, in light of some punishment factor, to grant a punishment reduction. The seriousness of the offense also affected decisions about the size of the change in punishment, if any change was made. Moreover, some punishment factors seem better suited for certain types of crimes than others. Few punishment factors have appeal no matter what the underlying offense. For example, while XPFs like paying substantial civil compensation were popular mitigating factors when the underlying offense was not serious, once a human death was involved, XPFs like victim forgiveness overtook them in popularity.

For the most part, lay judgments across demographics proved remarkably consistent. Differences attributable to age, income, or education level were few and slight. Likewise, while there were differences between whites and nonwhites, males and females, and married and unmarried respondents, neither XPF popularity nor XPF magnitude tended to differ in most cases among these demographic groups. Of the demographic variables tested, race seemed to have the biggest effect: whites were more likely to adjust punishment in response to XPFs than nonwhites, especially in response to mitigation XPFs, although whites were not more sympathetic to offenders overall, and the overall effect of race was relatively small.

There were slight differences between the two sample sets employed. Most of these differences were attributable to demographic differences between the samples. Those differences that could not be explained by demographic factors may have reflected either differences in testing conditions or, possibly, unquantifiable variables unique to the local Chicago sample.

253. XPF 4 ("True Remorse, Public Acknowledgment of Guilt, and Apology Immediately After Offense") turned out to be the most intuitively popular XPF, followed by XPF 9 ("Rehabilitated") and XPF 15 ("Has Already Paid Substantial Civil Compensation to the Victim"). XPF 4 in fact achieved majority support in three scenarios: Scenario A ("Theft with Trespass"), Scenario B ("Personal Injury"), and Scenario C ("Governmental Corruption"). 


\section{IMPLICATIONS FOR CRIMINAL JUSTICE RULES AND PRACTICES}

For many, if not most, of the XPFs noted in Part I there are ongoing discussions about the propriety of their use in assessing punishment. Many are part of larger debates, such as those regarding plea bargaining, restorative justice, the role of public outrage in sentencing, and the victims' rights debate on victim participation in sentencing. These discussions commonly focus on a variety of utilitarian and desert concerns, ${ }^{254}$ but all of them, we argue, are touched by the findings reported in Part II.

Two findings of Part II have particularly broad implications for criminal justice reform, taken up in Sections A and B below. First, the high level of disagreement regarding some XPFs highlights the problem of disparity in application. Second, the high level of agreement in supporting the use of some XPFs and in rejecting the use of others suggests that adjudication practices that conflict with these views are likely to undercut the system's moral credibility with the community it governs and thereby its ability to harness the powerful forces of normative and social influence. Finally, Section C compares the support for, or opposition to, each XPF reported in Part II, with the current practice in the use of that XPF as described in Part I.

254. There have been substantial debates on the utilitarian merits of particular XPFs. For instance, theorists have sparred over whether the practice of plea bargaining-an instance where an offender acknowledges his guilt-is warranted. See, e.g., Albert W. Alschuler, The Changing Plea Bargaining Debate, 69 CALIF. L. REV. 652, 671 (1981) ("Even to contemplate an exchange of human liberty for a purely economic benefit . . . may offend us and may seem inconsistent with a central value that society should strive to preserve."); Scott W. Howe, The Value of Plea Bargaining, 58 OKLA. L. REV. 599, 604-05 (2005) ("Prosecutors and judges willingly trade some deserved punishment in individual cases to maximize the punishments they can secure. They must make this trade-off because they have limited resources.”). Similar debates have focused on the merits of taking apology into account. See, e.g., Berry, supra note 98, at 884 ("As the genuineness of post offense conduct can easily be questioned, the benefit to the state of mitigating a sentence based on post offense conduct by the offender toward the victim will often not be apparent . . . ."); Bibas, supra note 38, at 339 ("While one cannot be certain, it is at least possible that apologetic, forgiven offenders are more likely to take their lessons to heart and less likely to recidivate."). Advancing utilitarian arguments, some scholars have advocated for a more prominent role of victims in sentencing. See, e.g., Erin Ann O'Hara \& Maria Mayo Robbins, Using Criminal Punishment to Serve Both Victim and Social Needs, 72 LAW \& ConTEMP. ProBs. 199, 201 (2009) (proposing that "victims should have control over a portion of the offender's criminal sentence"). Good deeds and rehabilitation as grounds for mitigation have been argued for on the grounds that such allowances at sentencing would incentivize such conduct. See, e.g., Hessick, supra note 66, at 1149 ("Just as the government may encourage guilty pleas and cooperation with law enforcement through sentence mitigation, so too could military service and charitable works be encouraged through mitigating sentences based on prior good acts."). 


\title{
A. Disagreements About XPFs and the Problem of Disparity in Application
}

As Part I notes, there exist a myriad of points in the criminal justice process at which a decisionmaker may choose to take account of, or to ignore, the existence of an XPF. A prosecutor may consider XPFs when deciding to prosecute an offender or when negotiating a plea bargain. A judge may consider an XPF at sentencing, occasionally upon legal authority, but more typically in the exercise of his sentencing discretion. In some trials, XPFs may come out during trial testimony and may be taken into account by jurors in determining a trial verdict. And in some sentencing regimes, ${ }^{255}$ juries also participate in the sentencing process and may consider an XPF in that context. Finally, parole boards and corrections officials may consider XPFs in deciding when to release an offender.

There seems to be general agreement that a central feature of fairness and justice is consistency in the application of punishment. Similar offenders committing similar offenses ought to receive similar punishment. One's punishment ought to depend upon one's offense, culpability, and capacities, not upon which decisionmaker one happens to draw. As the Senate Report to the Federal Sentencing Reform Act of 1984 put it:

\begin{abstract}
Sentencing disparities that are not justified by differences among offenses or offenders are unfair both to offenders and to the public. A sentence that is unjustifiably high compared to sentences for similarly situated offenders is clearly unfair to the offender; a sentence that is unjustifiably low is just as plainly unfair to the public. Such sentences are unfair in more subtle ways as well. Sentences that are disproportionate to the seriousness of the offense create a disrespect for the law. Sentences that are too severe create unnecessary tensions among inmates and add to disciplinary problems in prisons. $^{256}$
\end{abstract}

Yet, as Part II makes clear, there is enormous disagreement as to the propriety of the application of many XPFs, even when people are considering the exact same XPF for the exact same offense and

255. See Nancy J. King \& Susan R. Klein, Essential Elements, 54 VAND. L. REV. 1467, 1510 (2001) (noting that by the mid-twentieth century, thirteen states continued to allow sentencing by juries).

256. S. REP. No. 98-225, at 34 (1983), reprinted in 1984 U.S.C.C.A.N. 3182, 3228-29; see Michael M. O'Hear, National Uniformity/Local Uniformity: Reconsidering the Use of Departures to Reduce Federal-State Sentencing Disparities, 87 IowA L. REV. 721, 729 (2002) (quoting S. REP. No. 98-225, at 34). In United States v. Booker, Justice Breyer explained that Congress's basic goal in passing the Sentencing Act was increased uniformity in punishment. 543 U.S. 220, 253 (2005). The concept of uniformity can be described simply as encapsulating the "twin goals of (i) similar treatment of similarly situated offenders and (2) different treatment of differently situated offenders." Michael M. O'Hear, The Myth of Uniformity, 17 FED. SENT'G REP. 249, 249 (2005). 
offender, as occurs in the study. In more than $20 \%$ of the cells in Table 5 (nineteen of ninety), the subjects were almost evenly split, $40 \%$ to $60 \%$ or closer. In more than a quarter of the cells (twenty-five of ninety), there is a dissent of more than a third of the subjects. In almost half of the cells (forty-three of ninety), a quarter or more of the subjects are dissenting. There is little reason to think that these high levels of disagreement on some applications of some XPFs disappear among the police, prosecutors, judges, jurors, parole boards, and other criminal justice system decisionmakers. ${ }^{257}$ Yet, clearly it would be unacceptable if the chances that one's punishment depended on the luck of the draw of a decisionmaker were as random.

Indeed, even more egregious are situations where an offender faces a decisionmaker holding an idiosyncratic view. Imagine an offender being judged by a decisionmaker who falls into a small group of dissenters. More than half of the cells (forty-eight of ninety) in Table 5 show a minority view of $25 \%$ of less. Some of the XPFs had a dissenting group as small as $6 \%$. A lack of guidance in the application of XPFs invites the problem explicitly noted by the Senate: offenders receiving "more favorable or less favorable treatment because [they] happen[] to be sentenced by a particular judge." 258

Several examples illustrate the disparity problem. Consider the case of Frank Serafini, who was a popular Pennsylvanian state senator. ${ }^{259}$ Serafini was called to testify before a grand jury against a relative who was allegedly involved in an illegal scheme to funnel money through intermediaries to the Dole presidential campaign. Serafini denied knowledge, but when Serafini's aide was caught covering for the Senator, prosecutors charged Serafini with perjury and succeeded in convicting him at trial. The federal judge sentencing Serafini gave him a relatively light sentence, granting a three-level downward departure from the guideline sentencing range ${ }^{260}$ based on letters "contain[ing] substantive descriptions of Serafini's generosity with his time as well as his money. Several constituents and friends described situations in which Serafini extended himself to them in

257. As a general matter, there is disagreement between the population at large and sentencing officials on how strict the criminal justice system should be. See Stephanos Bibas, Transparency and Participation in Criminal Procedure, 81 N.Y.U. L. REV. 911, 928 (2006) (reviewing studies). As to what factors to take into account at sentencing, there is good reason to think that the judgment of criminal justice officials will often depart from that of nonspecialists. See Michael Tonry, The Functions of Sentencing and Sentencing Reform, 58 STAN. L. REV. 37, 43-45 (2005) (detailing the ways in which different people view the purposes of sentencing).

258. S. REP. NO. 98-225, at 79.

259. United States v. Serafini, 233 F.3d 758, 758 (3d Cir. 2000).

260. $I d$. at 778 . Serafini was required to serve five months in prison and five months under house arrest. 
unique and meaningful ways during times of serious need." 261 The letters convinced the sentencing judge that Serafini's prior good deeds "weren't acts of just giving money, they were acts of giving time, of giving one's self." 262 The Third Circuit upheld the departure.

Serafini's case closely approximates XPF 10 ("Good Deeds Before the Offense") in Scenario C ("Governmental Corruption"). Yet, only $15 \%$ of respondents found that the XPF should alter the offender's punishment. The court's decision to grant a downward departure for prior good deeds would seem to be at odds with the strong majority view of our lay participants.

The case of Edward Warfield provides another example. ${ }^{263}$ Warfield was a security guard at a white supremacist compound in Idaho. When a car stopped near the compound and backfired, Warfield mistook the sound as a gunshot. He and his confederates gave chase and shot at the car, which crashed in a ditch. Warfield then attacked the driver, who was white and whom he called a "white bitch." 264 Warfield was arrested and pled guilty to aggravated assault. Though couching the denial in terms of incapacitation, the judge clearly had Warfield's racism in mind when imposing the sentence, stating that "the Court is not persuaded that defendant has abandoned his interracial philosophy." 265 The judge denied Warfield's motion for a reduced sentence.

Although Warfield's racism would doubtlessly win him few supporters, likewise, our results suggest that few people would be willing to aggravate his punishment because of it. His case seems closest to XPF 12 ("Bad Deeds or Character") in Scenario B ("Personal Injury"), but only $20 \%$ of respondents thought that an aggravation of punishment was appropriate in that scenario. The sentencing judge in this case presumably is from that minority. ${ }^{266}$

Other cases are emblematic of the failure of decisionmakers to take into account XPFs that enjoy considerable public support. Donald Pennington, for instance, received a forty-eight-month sentence for

261. Id. at 773 .

262. $I d$. at 775 .

263. State v. Warfield, 34 P.3d 37, 37 (Idaho Ct. App. 2001).

264. Id. at 38 .

265. Id.

266. The case of Patrick Lett is similarly illustrative. Lett was a military veteran with an outstanding service record but fell into drug dealing. United States v. Lett, 483 F.3d 782, 782-87 (2007). The court, looking favorably upon his service as well as his decision to reenlist, gave Lett a substantial downward departure after a post-trial motion and sentenced him to time served-a mere 11 days. Id. Although the Eleventh Circuit overturned the sentence on appeal, Lett's case demonstrates the influence that even unpopular XPFs like prior good deeds may have on sentencing authorities. Id. 
abusing his position as president of a grocery chain by receiving secret payments and kickbacks. ${ }^{267}$ By the time of his sentencing, Pennington had been found liable to the grocery store company for $\$ 6$ million. The judge, however, refused to give Pennington any credit for this substantial civil fine, "conclud[ing] that an adverse judgment in a prior civil case involving the same fraudulent conduct is not a permissible basis to reduce the sentence for the criminal fraud." The Eighth Circuit agreed. But, if Pennington's case is an example of XPF 15 , then there may well be substantial lay support for such mitigation of punishment. If the underlying offense is seen as similar to the theftand-trespass scenario, then it has 65\% support; or, as seems more likely, if the underlying offense is more akin to the governmentalcorruption scenario, then it has $44 \%$ support. In other words, many respondents would have disagreed with the judge and would have granted Pennington some leniency in light of the hefty civil judgment.

Consider too the case of Tracy Westmoreland, who was convicted of criminally deviant conduct for inducing an underage partner to perform oral sex on him. ${ }^{268}$ Although Westmoreland was a minor at the time of the offense, by the time of sentencing he had started a family and showed how a prison sentence would be unduly hard on his family. The judge refused to grant any adjustment on family hardship grounds. ${ }^{269}$ If analogized to XPF 16 ("Hardship on Family") in Scenario B ("Personal Injury"), the judge's sentence may be in tension with the views of a majority of the respondents in that case.

The potential for disparity in application is exacerbated by the demographic differences in assessing XPFs reflected in Tables 9 and 10. While there is much agreement across demographics, there also is some disagreement. An offender's punishment ought not depend upon the particular demographic characteristics of the decisionmaker, be it a sentencing judge, a sentencing jury, or a prosecuting attorney exercising discretion in striking a plea and sentence agreement.

Thus, if XPFs are to be relied upon in assessing punishment, there are good reasons to articulate rules governing their use, or at least some informal guidance, both to better avoid abuse and to improve the uniformity in XPFs' application among different decisionmakers. For all offenders, punishment ought to depend upon

267. United States v. Pennington, 168 F.3d 1060, 1060 (8th Cir. 1999).

268. Westmoreland v. State, 787 N.E.2d 1005, 1005 (Ind. App. 2003).

269. On appeal, the appellate court reversed. $I d$. 
the same set of factors relevant to the case, not upon the personal preferences and idiosyncrasies of the individual decisionmaker. ${ }^{270}$

The strong trend in American criminal justice is to attempt to guide the exercise of discretion as much as possible, in large part out of a commitment to equality of treatment among similarly situated offenders. Toward that end, some parts of the system have experimented with using guidelines-some American jurisdictions have developed sentencing guidelines, parole release guidelines, or charging guidelines. As we better understand the affect that people give to XPFs, we will be better able to construct guidelines that articulate principles to guide reliance upon XPFs, wherever they may be used.

\section{B. Strong Support for, or Opposition to, an XPF and the Problem of Undermining the Law's Moral Credibility}

As one of us has argued elsewhere, there is reason to believe that there is good utility in a criminal justice system that distributes liability and punishment in concordance with the citizens' shared intuitions of justice. ${ }^{271}$ First, some of the system's power to control conduct derives from its potential to stigmatize violators-with some potential offenders this is a more powerful, yet an essentially cost-free, control mechanism when compared to imprisonment. Yet the system's ability to stigmatize depends upon it having moral credibility with the community. That is, for a conviction to trigger community stigmatization, the law must have earned a reputation for following the community's view on what does and does not deserve moral condemnation. Liability and punishment rules that deviate from a community's shared intuitions of justice undermine this reputation. ${ }^{272}$

Second, the effective operation of the criminal justice system depends upon the cooperation, or at least the acquiescence, of those involved in it-offenders, judges, jurors, witnesses, prosecutors, police, and others. To the extent that people see the system as unjust-as in conflict with their intuitions about justice-that acquiescence and cooperation is likely to fade and to be replaced with subversion and

270. This lack of uniformity may be impossible to adequately remedy at some stages of the criminal process, such as in prosecutorial charging decisions or in the decisions of law enforcement officers to pursue or abandon an investigation. Because these decisions are nonreviewable and not generally subject to public scrutiny, they may be difficult to address on a large scale.

271. Robinson, supra note 1, at 175-213; Robinson \& Darley, Intuitions, supra note 3; Robinson \& Darley, Utility, supra note 3; Robinson, Goodwin \& Reisig, supra note 3.

272. RoBInson, supra note 1 , at 176-78. 
resistance. Vigilantism may be the most dramatic reaction to a perceived failure of justice, but a host of other less dramatic (and more common) forms of resistance and subversion have appeared. Jurors may disregard their jury instructions. Police officers, prosecutors, and judges may make up their own rules. Witnesses may not offer their information or testimony. And offenders may be less likely to acquiesce to adjudication and correctional processes. ${ }^{273}$

The criminal law may gain compliance through another mechanism: if it earns a reputation as a reliable statement of what the community perceives as condemnable, people are more likely to defer to its commands as morally authoritative, especially in those borderline cases in which the community is uncertain as to the propriety of certain conduct. The importance of this role should not be underestimated. Since our society is complex and interdependent, a characteristically "victimless crime" may be anything but victimless. When a legal system criminalizes some action, an actor ought to respect the law regardless of whether he intuits the system's rationale. The widespread belief that the law is an accurate guide to prudential and moral behavior facilities such deference. ${ }^{274}$

Perhaps the greatest utility of empirical desert comes through a subtler, but potentially more influential, mechanism. The real power to gain compliance with society's rules of prescribed conduct lies not in the threat of official criminal sanction, but in the influence of the intertwined forces of social and individual moral control. The networks of interpersonal relationships in which people find themselves, the social norms and prohibitions shared among those relationships and transmitted through those social networks, and the internalized representations of those norms and moral precepts control people's conduct. The law is not irrelevant to these social and personal forces. Criminal law, in particular, plays a central role in creating and maintaining the social consensus necessary for sustaining moral norms. In fact, in a society as diverse as ours, the criminal law may be the only society-wide mechanism that transcends cultural and ethnic differences. Thus, the criminal law's most important real-world effect may be its ability to assist in building, shaping, and maintaining these norms and moral principles. It can contribute to and harness the compliance-producing power of interpersonal relationships and personal morality, but it will only be effective in doing so if it has sufficient credibility. ${ }^{275}$

273. Id. at $178-84$.

274. $I d$. at $187-89$.

275. Id. at $186-87$. 
The extent of the criminal law's effectiveness in all these respects-in bringing the power of stigmatization to bear; in avoiding resistance and subversion to a system perceived as unjust; in gaining compliance in borderline cases through deference to its moral authority; and in facilitating, communicating, and maintaining societal consensus on what is and is not condemnable-is to a great extent dependent on the degree to which the criminal law has gained moral credibility in the minds of its citizens. Thus, the criminal law's moral credibility is essential to effective crime control and is enhanced if the distribution of criminal liability is perceived as "doing justice"that is, if it assigns liability and punishment in ways that the community perceives as consistent with its shared intuitions of justice. Conversely, the system's moral credibility, and therefore its crimecontrol effectiveness, is undermined by a distribution of liability that conflicts with community perceptions of just desert. ${ }^{276}$

A recent empirical study confirms that distributing punishment in ways that conflict with people's judgments about justice does undermine the system's moral credibility with them, ${ }^{277}$ and, further, that such undermining does indeed have the negative practical effects suggested above. ${ }^{278}$ The study tested lay subjects' relative judgments of blameworthiness in cases involving the most popular modern crime-control doctrines: three strikes and other habitual offender statutes, high drug-offense penalties, adult prosecution of juveniles, abolition or narrowing of the insanity defense, strict liability, felony murder, and the criminalization of regulatory violations. It found that current law seriously conflicts with people's intuitions of justice by exaggerating the punishment deserved. ${ }^{279}$ It also found that these conflicts did indeed undermine the criminal justice system's reputation with people. More importantly, the study showed that that disillusionment translated into specific negative effects likely to hurt the law's crime-control effectiveness: it undermines people's willingness to comply with the law's prohibitions in cases where the reason for them is not clear to them as well as their willingness to assist authorities in enforcement efforts, participate themselves when needed, stigmatize conduct that the law punishes, and internalize the norms against conduct that the law condemns. ${ }^{280}$

276. Robinson, Goodwin \& Reisig, supra note 3, at 1995-2025.

277. Id. at 2001-08.

278. Id. at 2001-08, 2016-25.

279. $I d$. at $1961-79$.

280. Id. at 1995-2025. 
If the objective of criminal law is to build moral credibility with the community it governs, it should regularly take account of XPFs that have strong support in that community, which is not now done in any consistent fashion. For example, true remorse demonstrated by acknowledgment of guilt and apology before being a suspect (XPF 4) has strong support among laypersons in the study and dramatically reduces punishment. Indeed, it has support from a majority of participants for all offense scenarios except for the two homicide cases. A criminal justice system that ignores such an XPF risks being seen as deaf to the community's views of proper punishment.

At the same time, maintaining the criminal law's moral credibility with the community also means avoiding reliance upon XPFs that the community rejects as irrelevant to punishment. Seven of the XPFs had average support across all scenarios of $20 \%$ or less (XPFs $7,11,5,12,8,10$, and 13, in decreasing order of support). ${ }^{281}$ Allowing decisionmakers to rely upon these XPFs risks undermining the criminal law's moral credibility, thereby undermining its ability to harness the powerful forces of normative and social influence.

Of course, these conclusions are not without caveats. While the improper consideration (or lack thereof) of an XPF might have detrimental effects on the law's moral credibility, this can only occur if the treatment of the XPF is publicized. ${ }^{282}$ This detrimental effect is heavily dependent on accurate, detailed reporting by the media. If, for example, a court ignores an XPF in sentencing a defendant despite that factor's importance to the public, the law's moral credibility may only be harmed if the public learns that the XPF was ignored. ${ }^{283}$ Conversely, a court applying XPFs in accordance with the public's wishes might nonetheless be seen as unjust where the media fails to provide details of sentencing decisions. ${ }^{284}$ When a sentence is reported in isolation, which is the traditional news-coverage approach, it may seem inappropriate, yet an examination of a fuller collection of cases may suggest that it is indeed just the sentence this offender deserves, given his relative blameworthiness.

The demographic results reflected in Tables 9 and 10 and the local-national differences reflected in Table 13 also have implications for maximizing the system's moral credibility with the community it governs. To the extent that different communities hold somewhat different views about the propriety of one or another XPF, there might

281. See supra Table 5.

282. See Robinson \& Darley, Intuitions, supra note 3 (explaining these detrimental effects).

283. Id

284. Id. 
be value in having the system reflect those differences. And to the extent that different demographics of different areas predict different views on XPFs, then again differences in treatment of XPFs might be appropriate. Sometimes such regional differences might be feasible, such as in setting the policy for a city's sentencing courts. At other times, taking account of such differences will not be feasible, as in drafting state-wide or country-wide sentencing guidelines, although such guidelines might allow deviations where such regional differences are shown. On the other hand, the differences between regions and among different demographic groups tend to be sufficiently small that the failure to heed them might well have a minimal effect.

\section{Empirical Support vs. Current Use of XPFs}

The study reported in Part II reveals that lay intuitions about XPFs can be quite nuanced. For example, according to lay intuitions, an offender's reaction to his own offense is an important consideration at sentencing, but his character or past actions are less significant. Remorse, regret, and apology seem to mitigate punishment in people's judgments, but character on its own does not appear to be a powerful factor. For another example, the extent of an offender's suffering is an important consideration, and there seems to be substantial, consistent support for the idea that punishment ought to be tailored, if possible, to a defendant's unique circumstances, especially when he or those close to him may doubly suffer because of an official sanction. Still further, whether and to what extent a punishment factor should affect punishment often depends on the nature of the underlying offense. Judges, parole boards, or other sentencing officials who hope to track lay intuitions should think not only about the punishment factor presented to them but the nature of the underlying offense. In a number of situations, the underlying offense appears to alter the logic of mitigation or aggravation. Finally, lay intuitions seem to hold that punishment should more readily take mitigating XPFs into account when the underlying offense is not a serious one. The reverse, though, may not be true: lay intuitions do not increase the effect of aggravating XPFs when the underlying offense is more serious.

The implications for each XPF are discussed below.

\section{Offender Reaction to the Offense}

The first four XPFs vary in the degree of remorse expressed. In XPF 1, the offender offers a bare acknowledgment of guilt; in XPF 2, 
he adds an apology; in XPF 3, he convinces the sentencing authority of his remorse; and in XPF 4, he turns himself in. Unsurprisingly, XPF 4 enjoyed more support than XPF 3, which in turn enjoyed more support than XPF 2, and so forth. Notably, this group of offenses appeared to be the most intuitively powerful, suggesting that a punishment regime that takes into account an offender's remorse likely tracks lay intuitions, though the way in which it does so is important.

XPF 4 ("True Remorse, Public Acknowledgment of Guilt, and Apology Immediately After Offense"). XPF 4 offers the most extensive offender reaction of the XPFs in this group-the offender felt sincerely remorseful and turned himself in even though he had no reason to fear being caught. More people decided to mitigate the punishment for the offender who turned himself in than for any other offender in the study. Support ranged from $77 \%$ of respondents in the theft scenario to $40 \%$ of respondents in the murder scenario.

Still, there were some surprising details about XPF 4. First, while support for XPF 4 was substantial when the defendant committed theft or assault, when the defendant committed homicide most respondents did not believe any mitigation was warranted. Second, among those who believed mitigation was warranted, the average mitigation was somewhat muted, at least in comparison to other XPFs. It ranged from $44 \%$ for the murder offense to $68 \%$ for corruption. While those numbers are substantial, other XPFsnamely, XPFs relating to offender hardship - tended to receive larger mitigations. ${ }^{285}$ Third, even though corruption was considered a more serious offense than assault, more people believed that XPF 4 made a difference in the corruption case than in the assault case, and the corruption defendant received the largest mitigation (68\%) of any defendant among those subjects willing to mitigate on the basis of XPF 4.

Those jurisdictions that take sincere remorse into account are largely consistent with lay intuitions. But such jurisdictions often leave the decision of whether to take remorse into account wholly to the discretion of the sentencing judge. Moreover, no jurisdiction seems to take the sophisticated approach to remorse that lay intuitions suggest. $^{286}$ To many respondents, mitigation seems to be more warranted in a corruption case-perhaps because a public servant who acknowledges guilt voluntarily gives up all that he illicitly gained. Offenders who committed serious crimes like reckless

285. See supra Table 6.

286. See supra notes 24-30 and accompanying text (noting that "True Remorse" is often treated as a discretionary factor at sentencing). 
homicide and murder seem to be considered less deserving of any mitigation. It also seems that, standing alone, respondents consider sincere remorse to be less deserving of a large mitigation as are other punishment factors.

XPF 3 ("Truly Remorseful with Public Acknowledgment of Guilt and Apology"). Learning about an offender's true remorse at sentencing caused respondents to mitigate punishment $38 \%$ of the time-much lower than XPF 4's 61\%. Moreover, among those respondents who decided to mitigate, the average reduction was $41 \%$, less than XPF 4's 55\% average. Thus, jurisdictions that hope to track lay sentiment are right to credit true remorse at sentencing, but only those that distinguish between remorse at sentencing and remorse immediately after the offense truly track popular intuitions.

XPF 2 ("Public Acknowledgment of Guilt plus Apology"). A bare apology appealed to a substantial minority of people. On average, respondents changed their punishment 30\% of the time they encountered an apology without anything more. Those who did so gave an average reduction in punishment of $37 \%$. Again, jurisdictions aiming to approximate popular intuitions should thus distinguish between true remorse and a bare apology.

XPF 1 ("Public Acknowledgment of Guilt"). XPF 1 was unsurprisingly the least popular of the XPFs in this group. Across all defendants, respondents mitigated only $26 \%$ of the time, and when they did so they gave an average reduction of $34 \%$. Thus, a number of people may favor a reduction in light of a mere public acknowledgment of guilt, but not as many as would favor an acknowledgment of guilt with something more. Many jurisdictions require a showing that defendant who pleads guilty comply with police investigations, make efforts at victim restitution, or otherwise manifest more than a mere guilty plea. In light of these findings, those jurisdictions seem to better track lay sentiment.

\section{Victim or Public Reaction to the Offense}

XPFs in this category were generally among those with the least amount of support. Still, they enjoyed sizeable support when the severity of the underlying offense was minimal, perhaps reflecting the judgment that victims should have a say in punishment when the resulting harm was slight.

XPF 5 ("Forgiveness by Victim"). Victim forgiveness was consistently among the lowest-ranked XPFs, with the XPF influencing punishment decisions only $19 \%$ of the time. Support for mitigation in light of victim forgiveness also depended on the seriousness of the 
underlying offense: for the relatively minor crimes of theft and assault, for instance, victim forgiveness resulted in a change in punishment by $31 \%$ and $23 \%$ of respondents, but for reckless homicide and murder, only $16 \%$ and $12 \%$ of respondents supported mitigation. Moreover, offense seriousness had a significant effect on the magnitude of any mitigation: of those who decided to change punishment, the punishment reduction ranged from $18 \%$ for the assault to $7 \%$ for the murder. ${ }^{287}$ Thus, to the extent that current practice does not provide for victim forgiveness to be taken into account, it tracks majority sentiment among lay people, though some appear to disagree and believe that victim forgiveness makes a difference.

XPF 6 ("Victim Wants Less or No Punishment"). The desire by the victim for less punishment appears to be a more compelling reason for mitigation than is mere forgiveness by the victim. Even so, across all responses victim desire for less punishment made a difference only $27 \%$ of the time, and it enjoyed less support among respondents as offense seriousness increased, though it was among the more widely supported XPFs for the murder offense. But while XPF 6 never approached majority support, those who believed it made a difference sometimes gave substantial reductions: the theft defendant received an average reduction of $69 \%$ and the corruption defendant received an average reduction 58\%. The personal injury and murder defendants received a reduction of only $36 \%$ and $41 \%$, suggesting that perhaps the logic behind XPF 6 holds for property crimes but might not for crimes against the person. Any such nuance is lacking from current practice, especially since the desire by a victim for less punishment seems to come into play only when decisionmakers exercise their discretion.

XPF 7 ("Victim Wants More Punishment"). Across all scenarios, fewer people changed their punishment assignment because of a victim's desire for more punishment (27\%) than did people because of a victim's desire for less punishment (20\%). But, unlike XPF 6, support for XPF 7 did not seem to reflect the severity of the underlying offense: support ranged between 19\% and 25\%. Moreover, when respondents decided that a change was warranted, the aggravation was substantial only in the case of the theft and assault defendants, who saw a $36 \%$ and $47 \%$ increase in sentence length, respectively. For the corruption, reckless homicide, and murder

287. Interestingly, those who mitigated punishment for the corruption offense only did so by an average of $5 \%$. This may reflect the understanding that corruption-in effect a breach of the public's trust-may be the type of crime for which victim forgiveness does not mean much. 
defendants, the increase ranged from negligible to $13 \%$. Thus, the apparent consensus in current practice against taking into account a victim's desire for more punishment seems consistent with lay intuitions. Even though a sizeable proportion did favor aggravation, the increase that they on average favored was noteworthy only for the theft and assault offenses.

XPF 8 ("Public Outrage over Offense"). In XPF 8, subjects were told about considerable public outcry surrounding the offender's conduct. While this was an artificial way to gauge subjects' reaction to public outrage-being told about a public reaction is different than experiencing it-few people actually felt compelled to change their punishment assignment. On average, respondents elected to change punishment assignments only $16 \%$ of the time after being informed about public outrage. When they did so, the increase was low: of those who changed, the increase was an average of $24 \%$. It may be fair to say then that the reluctance of courts to heed public calls for harsher punishment may after all be in accordance with lay understandings of the proper insulation of the individual punishment decision from public opinion.

3. Offender Status or Characteristics Unrelated to Commission of the Offense

Decisionmakers often look to an offender's character, prior record, efforts at rehabilitation, or rehabilitative potential. Somewhat surprisingly, few XPFs relating to offender status elicited strong reactions from the study sample. The strongest XPF in this grouppostconviction rehabilitation-is the outlier, perhaps because a sincere effort at rehabilitation might be taken as a sign of remorse.

XPF 9 ("Rehabilitated"). XPF 9 focused on postoffense, presentencing rehabilitation, which the Supreme Court recently endorsed. ${ }^{288}$ The study's findings suggest that the Court's ruling in Pepper enjoys widespread intuitive support. For the minor theft and assault scenarios, a majority of study respondents changed their sentence when postoffense rehabilitation was at play, and a substantial minority of respondents did so in the more serious scenarios. Moreover, the magnitude of punishment adjustment held steady at between -0.32 for the theft-with-trespass scenario and -0.26 for the intentional-killing-and-abduction scenario, which in percentage terms corresponds to a decrease in sentence mitigation from $20 \%$ to

288. Pepper v. United States, 131 S. Ct. 1229, 1229 (2011); see also supra notes 91-94 and accompanying text (discussing this case). 
$16 \%$. Among those who actually chose to change punishment, the mitigation increased from a low of $29 \%$ in the personal-injury scenario to a high of -0.83 (or $44 \%$ ) in the intentional-killing-and-abduction scenario. ${ }^{289}$ By way of contrast, the district court in Pepper awarded the defendant, who pled guilty to conspiracy to distribute five hundred grams or more of methamphetamine, a $59 \%$ reduction for his postoffense rehabilitation. ${ }^{290}$

Thus, rehabilitation is not only an XPF with significant support, but it is also one that can carry with it a substantial reduction in punishment. Moreover, rehabilitation's intuitive appeal to those who give it deference becomes more attractive, not less, as offense seriousness increases. No jurisdiction seems to endorse the view that one who commits a serious offense is entitled to a greater mitigation for postoffense rehabilitation than one who commits a less serious offense. ${ }^{291}$

There may be some ambiguity in the results as to how respondents interpreted XPF 9. Respondents who mitigated in light of XPF 9 may have been struck not by the fact that the rehabilitation was successful, but that it exhibited the offender's remorse. If so, the results may lend additional support to the strong intuitive appeal of that XPF.

XPF 10 ("Good Deeds Before Offense"). While many have argued that an offender's good deeds or character should be taken into account and several jurisdictions in fact instruct or allow judges to do so at sentencing, ${ }^{292}$ the study here revealed that such considerations failed to substantially influence lay intuitions about deserved punishment. Only $15 \%$ of respondents found any departure warranted when XPF 10 was at issue, and, of those who did mitigate, the reduction ranged between $24 \%$ and $30 \% .{ }^{293}$ Thus, the U.S. Sentencing Commission, which says that "[m]ilitary ... [,] civic, charitable, or public service; employment related contributions; and similar prior good works are not ordinarily relevant in determining whether a departure is warranted," seems to track lay sentiment. ${ }^{294}$

289. ESN values of -0.50 and -0.83 , respectively.

290. Pepper, 131 S. Ct. at 1236-37. The District Court also cited Pepper's "lack of a violent history and, to a lesser extent, the need to avoid unwarranted sentencing disparity with Pepper's co-conspirators." Id. at 1237 n.3.

291. Indeed, the Sentencing Reform Act may be read to take the opposite view. It instructs judges to take into account inter alia the "seriousness of the offense," but is silent regarding postconviction rehabilitation. 18 U.S.C. § 3553(a)(2) (2006).

292. See supra Part I.C.1.

293. In ESN values, -0.39 and -0.52 respectively. See supra Table 6.

294. U.S. SENTENCING GUIDELINES MANUAL § 5H1.11 (2004). 
XPF 11 (“Good Deeds After Offense"). XPF 11 enjoyed only slightly more support than XPF 10 . Across all scenarios, only $19.6 \%$ of the time did respondents feel that XPF 11 warranted a departure, and many fewer thought so in the murder scenarios than in the theft or assault scenarios (10\%, 26\%, and $29 \%$, respectively). The magnitude of the departure among those who felt it was warranted was unsurprisingly larger than for XPF 10, but not by much: the reduction ranged from $28 \%$ to $48 \%$ of the original sentence. ${ }^{295}$

XPF 12 ("Bad Deeds or Character"). Prior criminal record is, of course, an almost universal aggravation in current sentencing practice. ${ }^{296}$ Prior criminal record is not an XPF, but rather formally part of the legal sentencing rules. But because XPF 12 presented something analogous to a criminal record-bad character expressed in a manner unconnected to the nature of the crime-one might expect that it too would have broad appeal. In fact, XPF 12 was among the least popular of the XPFs tested. Across all scenarios, only $17 \%$ thought that the offender's racism warranted a sentencing enhancement. Moreover, the enhancement differed widely in size. For instance, of those who thought that XPF 12 made a difference in the personal-injury scenario, the average enhancement was $64 \%$; of those who thought the same in the governmental-corruption scenario, the average enhancement was only 4\%. Hence, an offender's unsavory character does not appear to substantially influence lay judgment about proper punishment. Moreover, the magnitude of any enhancement seems highly contingent on the underlying offense in ways that are not clear from the data here.

XPF 13 ("Special Talents"). Here, XPF 13 tested the notion of "Special Talents" by informing subjects that the offender was a world-class actor. That fact seemed to persuade relatively few respondents-between $6 \%$ and $14 \%$, depending on the underlying offense. More surprising was the fact that many seemed to consider XPF 13 to be an aggravating factor, even though the consensus among sentencing authorities is that talent, if a factor at all, is a mitigating one. In the minor-theft scenario, for instance, respondents who changed punishment in light of XPF 13 on average increased punishment by $83 \% .{ }^{297}$ But in the murder scenario, respondents who

295. In ESN values, -0.48 and -0.74, respectively.

296. E.g., Berman, supra note 64 ("[E]very sentencing system (guideline or otherwise) provides for sentence enhancements (often huge enhancements) based on . . . a record of prior bad deeds.”).

297. In ESN value, +0.87 . 
changed punishment on average decreased punishment by $34 \% .{ }^{298}$ Hence, special talent, as a punishment factor, also seems to be highly contingent on the underlying offense.

\section{Suffering Apart from Official Punishment}

Factors relating to an offender or third party's suffering exhibit significant levels of support, but that support seems to rely heavily on the underlying offense. Indeed, for each of the XPFs below, the scenario in which the XPF was tested had a significant impact on both XPF popularity and magnitude. ${ }^{299}$ But while it seems clear that the popularity of these XPFs declines as offense seriousness increases, $\mathrm{XPF}$ magnitude and offense seriousness seem to interact in nuanced, nonobvious ways.

XPF 14 ("Already Suffering as a Result of the Offense"). XPF 14 presented respondents with the additional fact that the offender slipped and fell during his escape, breaking his neck and paralyzing himself. This fact convinced subjects to mitigate punishment $33 \%$ of the time. While $46 \%$ of respondents decided to mitigate punishment when XPF 14 was at play in theft-offense scenario, only $14 \%$ did so in murder scenario. This drop-off in support likely reflects the intuitive judgment that as the seriousness of the crime increases, the tendency for the offender's injury to offset any punishment decreases. Thus, courts seem to be acting in accordance with lay judgment when they find in only exceptional cases that "further legal penalties would be dwarfed by the suffering . . . already endured." 300 In fact, there seems to be some support for providing mitigation for minor offenses, like theft with trespass.

Nevertheless, those who found XPF 14 persuasive typically awarded the offender large discounts, and those discounts increased as offense seriousness increased. ${ }^{301}$ Subjects who mitigated punishment for XPF 14 decreased punishment on average 68\%, 49\%, $70 \%, 76 \%$, and $83 \%$ for Scenarios A through E, respectively. This decrease may be due to the fact that subjects were unwilling to deduct too much time from the comparatively short sentences at stake in Scenarios A and B, that subjects thought that the offender's paralysis rendered him incapacitated and no longer a threat to society, or that subjects felt that the logic of XPF 14 became more compelling as

298. In ESN value, -0.59.

299. See supra Tables $7 \& 8$.

300. City of Auburn v. Hedlund, 201 P.3d 315, 319 (Wash. 2009).

301. Indeed, our analysis found significant differences among mean responses. See supra Table 7. 
offense seriousness increased. In any case, no sentencing regime seems to consider suffering as a result of the offense in the same nuanced way that subjects did here.

XPF 15 ("Has Already Paid Substantial Civil Compensation to the Victim"). XPF 15 told subjects that the offender was judged liable in a civil proceeding and was required to pay substantial compensation. This factor was a relatively popular one, altering punishment judgments $41 \%$ of the time. The popularity of XPF 15, however, seemed to depend heavily on the underlying offense. While a clear majority of respondents (65\%) thought XPF 15 should mitigate punishment when the offender committed theft with trespass, only $14 \%$ thought so when he committed an intentional killing. This finding may reflect the understanding that a monetary "fine" may be enough of a punishment for theft, but for more serious offenses a fine is not enough to even mitigate prison time. Indeed, while XPF 15 was the second-most popular XPF in Scenarios A through $\mathrm{C}$, in Scenario $\mathrm{E}$ it fell to tenth. Moreover, even those respondents who decided to mitigate punishment felt that less mitigation was deserved as offense seriousness increased. In the theft scenario, the average mitigation among those who decided to mitigate was $67 \%$, but in the murder scenario that figure was $19 \%$.

Courts seem to worry about taking account of civil compensation because they do not want to create economic disparities among sentences. Our findings, however, suggest that courts concerned about lay intuitions should be less worried, especially when relatively minor offenses are at issue. On the other hand, the findings also may suggest that under current practice people seem to equate civil and penal sanctions. If we are tracking lay intuitions to maximize the moral credibility of criminal law and thus gain the benefits discussed in Part III.B immediately above, one might want to work hard to distinguish criminal and civil sanctions in people's minds. ${ }^{302}$ If that were one's goal, then taking account of civil sanctions in assessing criminal punishment would only undermine the effort to distinguish the two.

XPF 16 ("Hardship for Offender's Family or Others"). XPF 16 confronted respondents with the fact that punishment would result in depriving the offender's child of his or her sole caregiver. For the less serious offenses of theft and assault, a significant minority of respondents thought that punishment should be mitigated, presumably to ease the burden on the offender's child. Like other

302. See generally Paul H. Robinson \& Michael M. Cahill, LaW Without Justice 218-29 (2006) (discussing these benefits and distinguishing between types of sanctions). 
XPFs in this group, hardship for the offender's family convinced fewer subjects as the seriousness of the offense increased. Indeed, while $45 \%$ of respondents would have supported a reduction for the theft defendant, only 15\% would have supported that result for the murder defendant. Likewise, the magnitude of any reduction depended on the seriousness of the underlying offense. ${ }^{303}$

Current practice, which sometimes allows for mitigations in circumstances like this one, may indeed approximate lay judgment regarding hardship for others. The U.S. Sentencing Guidelines, for example, state that the court should consider "the seriousness of the offense" in deciding on any departure. ${ }^{304}$

XPF 17 ("Hardship for Offender Himself"). As opposed to $\mathrm{XPF} 16$, the claim here is that the punishment imposed may have a special hardship for the offender, in a way analogous to the operation of XPF 16, where the punishment presents a special hardship for the offender's family. Subjects were told that the offender was recently in a car accident, from which he is paralyzed. They responded less favorably than they did to XPF 16: on average, only $28.0 \%$ of respondents thought that mitigation was justified under XPF 17, compared to $35.9 \%$ under XPF 16 .

Interestingly, those who thought that the defendant here deserved mitigation tended to give a fairly large one: on average, the magnitude of the recorded change was $78 \%$, which was the largest average mitigation among any of the XPFs tested. Moreover, this sizeable mitigation by respondents was recorded across all offenses. Thus, while few thought that mitigation was justified, those who did were willing to grant substantial reductions to the offender at issue.

XPF 18 ("Old Age"). XPF 18, though dealing only with the offender's old age, exhibited many of the same characteristics as did other XPFs relating to offender suffering. As with XPFs 14 through 17 , more respondents elected to mitigate in light of XPF 18 when the offense was less serious. (XPF popularity ranged from $33 \%$ for theft to $10 \%$ for murder.) Unlike XPFs 14 through 17, however, the effect of the underlying offense seemed less pronounced, ranging only between a low of a $51 \%$ reduction for the theft offense and a high of a $75 \%$ reduction for the reckless homicide offense. Thus, while XPF

303. For Scenarios A through E, the magnitude of the reduction among subjects who chose to mitigate was $61 \%, 57 \%, 73 \%, 72 \%$, and $51 \%$, respectively. The unusual uptake in magnitude for Scenarios $\mathrm{C}$ and $\mathrm{D}$ may reflect considerations about letting the offender out in time to actually provide care for the child.

304. U.S. SENTENCING GUIDELINES § 5H1.6 cmt. note 1(a)(i) (2010). 
magnitude varied in significant ways among offenses, it did so in ways that are not clear from this analysis.

Still, the number of people who find old age persuasive as a reason for mitigating punishment clearly declined as offense seriousness increased. In this regard, lay intuitions seem similar to settled practice, which grant the mitigation in only exceptional circumstances. But current practice may depart from lay intuitions when it does not allow leniency in less serious offenses. Those jurisdictions that take old age into account do not seem to consider offense seriousness when doing so. ${ }^{305}$

\section{CONCLUSION}

Part I documents a wide variety of factors that can influence punishment in current practice but that are generally not recognized by existing criminal law. These "extralegal punishment factors" can influence the judgment of decisionmakers throughout the criminal justice process, such as when prosecutors decide what charge to press, when judges decide which sentence to impose, when parole boards decide when to release a prisoner, and when executive officials decide whether to grant clemency, as well as in less-visible exercises of discretion, such as in decisions by police officers and trial jurors.

As the empirical findings reported in Part II make clear, there is broad support for the use of some XPFs in determining punishment (and all XPFs had some support). On the other hand, most XPFs have only minority support: half had the support of less than a third of the study participants. The extent of an XPF's support, and the extent of the effect it had in adjusting punishment, commonly depended upon the nature of the underlying offense. Interestingly, the relative popularity among the XPFs also was dependent upon the nature of the underlying offense. Some XPFs were popular or unpopular throughout, but the popularity of others changed, as with XPFs that lost relative popularity as the offense became more serious. Both the level of support and the effect of some XPFs depended upon the demographic characteristics of a subject. For example, being white, male, unmarried, older, richer, or more educated commonly predicted a greater willingness to give the XPF mitigations tested here, though

305. See, e.g., U.S. SENTENCING GUIDELINES §5H1.1 (“Age may be a reason to depart downward in a case in which the defendant is elderly and infirm and where a form of punishment such as home confinement might be equally efficient as and less costly than incarceration.”); see also State v. de la Garza, 675 P.2d 295, 296 (Ariz. Ct. App. 1983) (“[E]xtreme youth or old age only becomes a mitigating factor when, because of immaturity or senility, the defendant lacks substantial judgment in committing the crime.”). 
there are exceptions. Finally, we found differences in the treatment of some XPFs, for some kinds of offenses, between our local and our national sample.

The study's findings suggest a variety of implications for criminal law and justice policy and practice. In addition to a host of specific critiques of current practice for each of the XPFs, Part III notes two broad implications. First, the high level of disagreement regarding some XPFs suggests that guidance is needed in what is currently an entirely discretionary application. An offender's punishment ought not depend upon the luck of the draw of decisionmaker. Second, our documentation that current practice can commonly conflict with shared community views on XPFs also suggests that some guidance, no matter how informal, may be useful. If the criminal justice system is to maintain its moral credibility with the community it governs, and thereby harness the powerful forces of social and normative influence, it cannot be seen as giving deference to an XPF that the community rejects nor as ignoring an XPF that the community broadly supports, yet we show that this does indeed happen in current practice. 